\title{
Experiment Operations Plan for a Loss-of-Coolant Accident Simulation in the National Research Universal Reactor
}

Prepared by G. E. Russcher, L. W. Cannon, R. L. Goodman,

G. M. Hesson, L. L. King, P. N. McDuffie,

R. K. Marshall, C. Nealley, J. P. Pilger, C. L. Mohr

Pacific Northwest Laboratory

Operated by

Battelle Memorial Institute

Prepared for

U.S. Nuclear Regulatory

Commission 


\section{NOTICE}

This report was prepared as an account of work sponsored by an agency of the United States Government. Neither the United States Government nor any agency thereof, or any of their employees, makes any warranty, expressed or implied, or assumes any legal liability or responsibility for any third party's use, or the results of such use, of any information, apparatus product or process disclosed in this report, or represents that its use by such third party would not infringe privately owned rights.

Available from

GPO Sales Program

Division of Technical Information and Document Control

U. S. Nuclear Regulatory Commission Washington, D. C. 20555

Printed copy price: $\$ 4.75$

and

National Technical Information Service

Springfield, Virginia 22161 
NUREG/CR-1735

PNL -3551

33679000555179

EXPERIMENT OPERAT IONS PLAN

FOR A LOSS-OF -COOLANT ACCIDENT SIMULATION

IN THE NATIONAL RESEARCH UNIVERSAL REACTOR
G. E. Russcher
L. W. Cannon
R. L. Goodman
G. M. Hesson
L. L. King
P. N. McDuffie
R. K. Marshall
C. Nealley
J. P. Pilger
C. L. Mohr, Program Manager

Manuscript Completed: October 1980

Date Published: April 1981

Prepared for

Division of Reactor Safety Research

Office of Nuclear Regulatory Research

U.S. Nuclear Regulatory Commission

Washington, DC 20555

FIN No. B2277

Pacific Northwest Laboratory

Richland, Washington 99352 



\section{ACKNOWLEDGMENTS}

This document was prepared in cooperation with the staff of Chalk River Nuclear Laboratories, Atomic Energy of Canada, Ltd. The detailed and useful discussions with D. J. Axford, B. DeAbreu, S. Z. Hart, P. E. Kelly, S. H. Kendrick, I. C. Martin, D. T. Nishimura (together with many others) of the Chalk River Nuclear Laboratories are appreciated. C. L. Wilson, PNL on-site representative at Chalk River for the LOCA Simulations program, was instrumental in coordinating discussions and reviewing data for the report.

The authors also wish to acknowledge the superlative efforts of the editor, Edye Jenkins and word processor, Kelly Feuerbacher, both of PNL. 



\section{ABSTRACT}

Pressurized water reactor loss-of-coolant accident phenomena are being simulated with a series of experiments in the U-2 loop of the National Research Universal Reactor at Chalk River, Ontario, Canada. The first of these experiments includes up to 45 parametric thermal-hydraulic tests to establish the relationship between the reflood delay time of emergency coolant, the reflooding rate, and the resultant fuel rod cladding peak temperature.

This document contains both experiment proposal and assembly proposal information. The intent of this document is to supply information required by the Chalk River Nuclear Laboratories (CRNL), and to identify the planned procedures and data that will be used both to establish readiness to proceed from one test phase to the next and to operate the experiment. Operating control settings and limits are provided for both experimenter systems and CRNL systems. A hazards review sumarizes safety issues that have been addressed during the development of the experiment plan. 


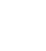




\section{SUMMARY}

Pacific Northwest Laboratory (PNL) is conducting a series of experiments in the U-2 loop of the National Research Universal (NRU) Reactor at Cha ik River, Ontario, Canada, to evaluate the consequences of a hypothetical loss-ofcoolant accident (LOCA) in a pressurized water reactor (PWR).

A LOCA occurring in a PWR involves four major, distinct phases: blowdown, heatup, reflood, and quench. Each phase involves a path-dependent process that is a function of 1) the type of event that initiated the accident and 2) the reactor operating conditions at the time the LOCA was initated. No single set of conditions would exist at the time any LOCA occurred. Rather, a broad range of operating parameters could exist in one of many possible combinations. Consequently, a parametric investigation of the independent variables that play a major role in determining the effects of a LOCA and its recovery is planned for the NRU-LOCA experiments.

During the most damaging LOCA phases, heatup, reflood, and quench, the highest predicted fuel cladding temperatures are reached. During the reflood phase, controlled by the reflood delay time and reflood rate, the cladding temperature and possibly the fuel cladding oxidation continue to increase until the reflood water reaches a sufficient depth to halt the increasing fuel cladding temperature, and finally, quench the cladding.

The first of these experiments being conducted by PNL includes up to 45 parametric thermal-hydraulic tests to establish the relationsh ip between the reflood delay time of emergency coolant, the reflooding rate, and the resultant fuel rod cladding peak temperature. Pacific Northwest Laboratory will provide the test train, the test fuel assembly, the data acquisition, reduction and anaiysis, and the management of the LOCA simulation program. Atomic Energy of Canada, Ltd. will provide the test facilities, the irradiation space in the NRU Reactor, and operation and support of the facilities. 



\section{CONTENTS}

ACKNOWLEDGMENTS

i ii

ABSTRACT

SUMMARY

1.0 INTRODUCTION

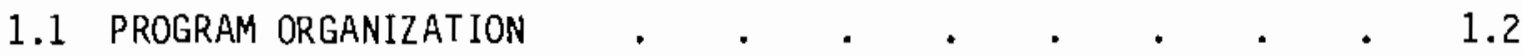

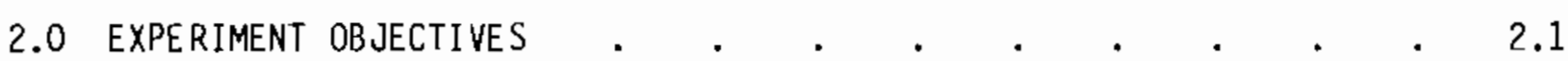

2.1 PROTOTYPIC THERMAL-HYDRAULIC EXPERIMENT • • • • . $\quad$ • 2.2

3.0 TEST TRAIN ASSEMBLY, INSTRUMENTATION AND FACILITY DESCRIPTIONS $\quad 3.1$

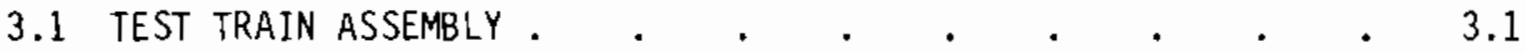

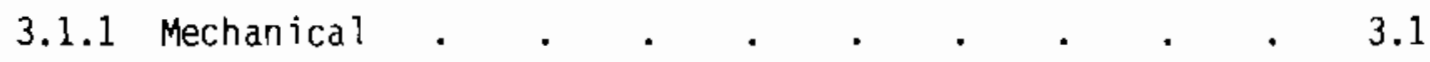

3.1 .2 Instrumentation . . . . . . . . . 3.4

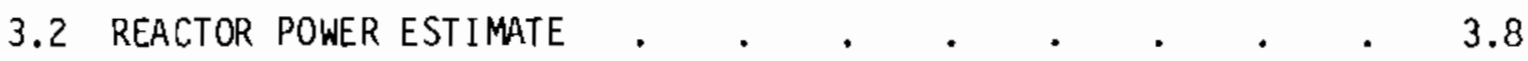

3.3 PRESSURE TUBE.$\quad$. . . . . . . . . . . . . . . 3.8

3.4 LOOP IRRADIATION FACILITY $\quad$. $\quad$. . . . . . 3.10

3.4.1 Loop Description . . . . . . . . 3.10

3.4.2 Steam and Reflood Loop Control System . . . . . 3.11

3.5 DATA ACQUISITION AND CONTROL SYSTEM $. \quad . \quad . \quad . \quad$. 3.13

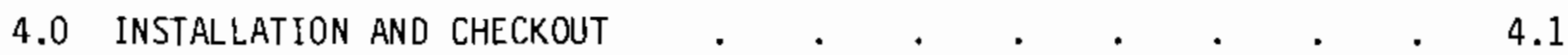

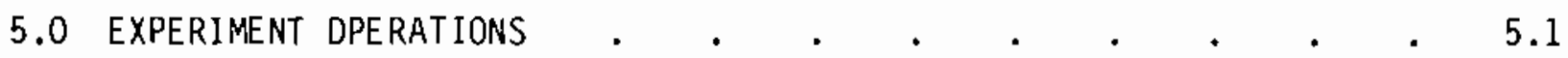

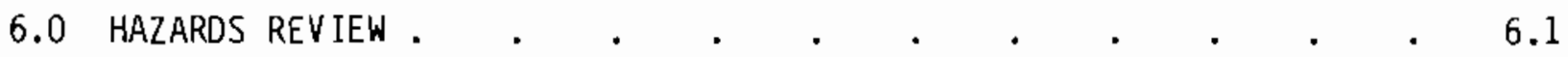

6.1 NORMAL REFLOOD EFFECTIVENESS . $\quad . \quad \ldots \quad$. $\quad . \quad$. 6.1

6.2 EXPECTED AND HYPOTHETICAL RADIDACTIVITY RELEASES . $\quad 6.2$

6.3 LOSS OF COOLANT DURING PRECONDITIONING $\quad . \quad . \quad . \quad . \quad . \quad 6.3$

6.4 LOSS OF REFLOOD AND TRIP . $\quad . \quad \ldots \quad$. $\quad . \quad . \quad . \quad . \quad 6.4$ 
6.5 LOSS OF REFLOOD AND STANDBY REFLOOD INITIATED $\quad$ • . $\quad 6.5$

6.6 PARTIAL LOSS DF REFLOOD COOLANT . . . . . . . . 6.9

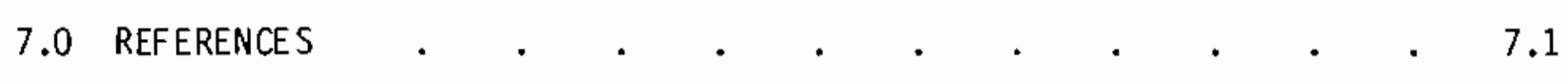

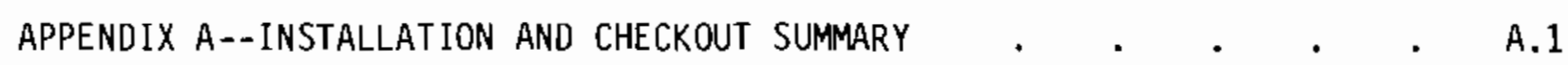

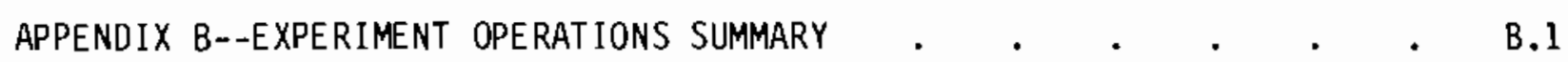

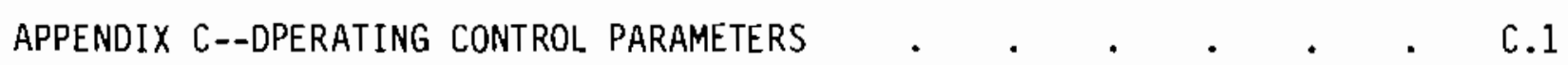

APPENDIX D--TRIP SETPOINT DESCRIPTION

APPENDIX E--FUEL ROD IDENTIFICATION AND DATA . . . • . . . . E.1

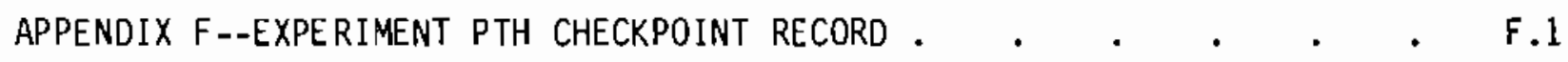

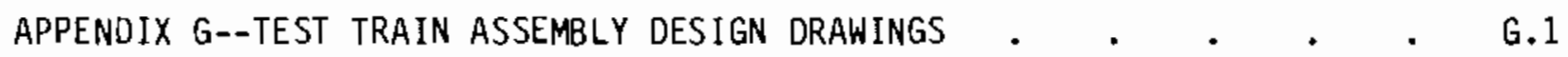

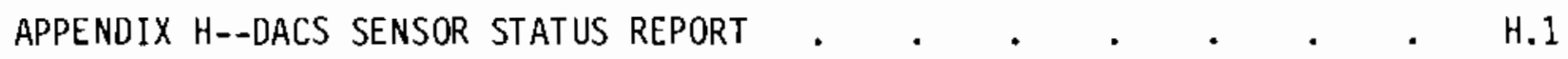




\section{FIGURES}

2.1 Schematic of Test Series Operating Conditions and Uncertainty $\quad 2.6$

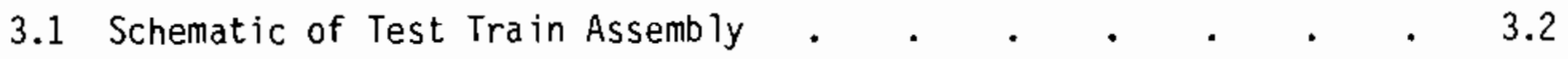

3.2 Cross Section of Test Assembly, Pressure Tube and Liner Tube - 3.3

3.3 Test Section Instrument Locations . . . . • . . 3.5

3.4 Test Assembly Instrumentation . . . . • • . . • 3.6

3.5 Schematic of Steam and Reflood Loop System . . . . . 3.11

4.1 Activity Flow Chart . . . . . . . . . . 4.2

6.1 NRU Power Decay After Trip . . . . . . . . . 6.5

6.2 Test Assembly Temperatures After a Trip . . . . . . . . 6.6

6.3 Temperatures Above Test Assembly After a Trip with No Steam Flow . 6.7

6.4 Effect of Reflood Rate on Fuel Cladding Temperature Rise . $\quad 6.8$

6.5 Contribution of Metal-Water Reaction to Rod Power . . . . 6.10

6.6 Shroud, Pressure Tube, and Test Fuel Cladding Temperatures for
$21-$ s Heatup, Slow Refiood and Reactor Trip at 1478K (22000F) . 6.11

D.1 Maximum Hypothetical Heatup Rate and Temperatures for the Test
Tra in Assembly. . . . . . . . . . . . . .

D.2 Axial Temperature Profile and Standard Trip Setpoints for
Transient Operation of Test EXP-PTH-138. $. \quad . \quad . \quad 0.5$ 


\section{TABLES}

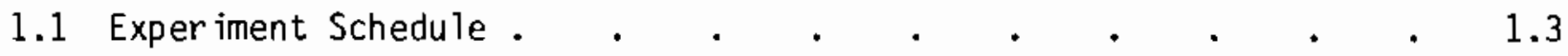

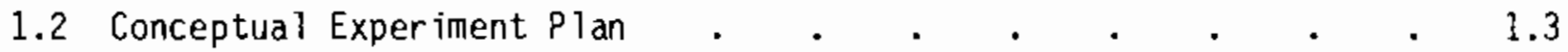

1.3 Experiment Personnel Responsibility $\quad$. $\quad . \quad$. $\quad$. . . . 1.4

2.1 Prototypic Thermal-Hydraulic Test Series Plan . . . . . 2.3

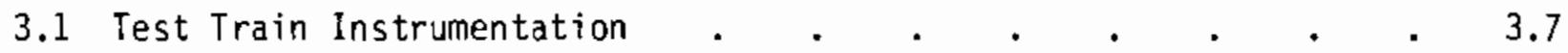

3.2 Reactor and Test Assembly Power Estimates . $\quad$. 3.8

3.3 Pressure Tube Safety Factors . . . . . . . . . . . 3.9

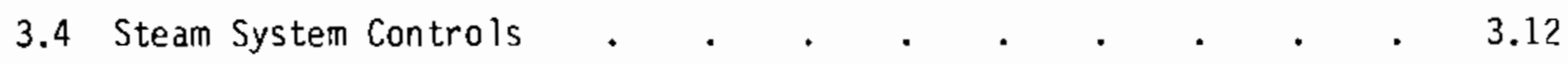

3.5 Reflood System Controls . . . . . . . . . . . . . . 3.13

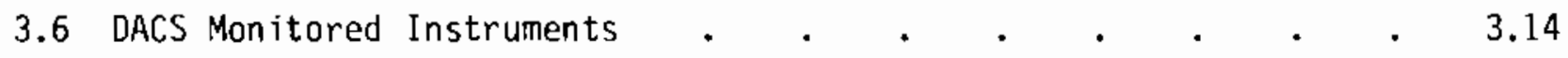

4.1 Installation and Checkout Schedule . . . . . . . . . . 4.3

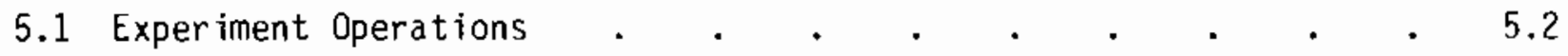

6.1 Difference Between the LOCA Simulation Experiment and the FLECHT Tests . . . . . . . . . . . 6.1

6.2 Estimated Radioactive Releases for a Hypothetical Accident . . 6.3

C.1 Preconditioning Operation Sumary.$\quad$.

C.2 Pretransient Operating Condition Summary . . . . . . . C.4

C.3 Transient Operating Condition Sumary . . . . . . . . . . c c.4

C.4 Prototypic Thermal-Hydraulic Test Series Plan . . . . . c.5

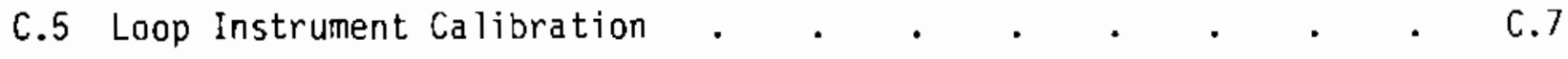

C.6 Water Chemical Requirements . . . . . . . . . . C.8

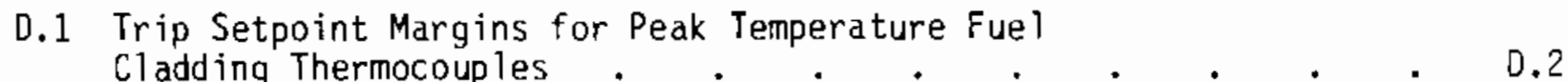

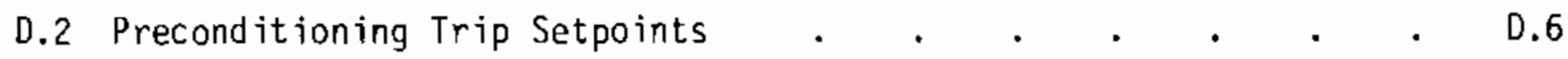

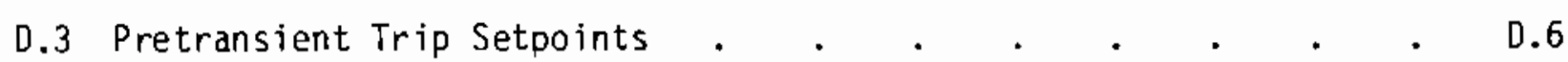


D.4 Transient Trip Setpoints . . . . . . . . . . . . D.7

0.5 Trip Setpoint Criteria for Dperating and Non-Functional
Fuel Cladding Thermocouples . . . . . . . . . . . 0.8 


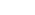




\subsection{INTRODUCTION}

Pacific Northwest Laboratory $(P N L)^{(a)}$ is conducting tests for the Nuclear Regulatory Commission (NRC), Division of Reactor Safety Research, Fuel Behavior Branch, to evaluate the consequences of a hypothetical loss-of-coolant accident (LOCA) in a pressurized water reactor (PWR). Pacific Northwest Laboratory will provide the test train, the reactor fuel assembly for the test, the data reduction and analysis, and the management of the LOCA simulation program. Atomic Energy of Canada, Ltd. will provide the test facilities and irradiation space in the Canadian National Research Universal (NRU) Reactor at the Chalk River Nuclear Laboratories (CRNL), Chalk River, Ontario.

A LOCA in a commercial PWR involves four major, distinct phases: blowdown, heatup, reflood, and quench. Each of these phases involves a pathdependent process that is a function of 1) the type of event that initiated the accident and 2) the reactor operating conditions at the time the LOCA was initiated. No single set of conditions would exist at the time any LOCA occurred. Rather, a broad range of operating parameters could exist in one of many possible combinations. Consequently, a parametric investigation of the independent variables that play a major role in determining the effects of a LOCA and its recovery is planned for the NRU-LOCA experiment.

Ouring the most damaging LOCA phases, heatup, reflood, and quench, the highest fuel cladding temperatures are reached, with the maximum pressure differential occurring across the fuel cladding wall. The pressurized cladding may rupture, releasing fission products early in the heatup phase. During the reflood phase, the cladding temperature and possibly the fuel cladding oxidation continue to increase until the reflood water reaches a depth sufficient to halt the increasing fuel cladding temperature, and finally, quench the cladding.

This document presents information that describes the NRU-LOCA experiment, including a master operating procedure or sumary test plan that will be used

(a) Operated by Battelle Memorial Institute 
to perform the experiment. Detailed operating procedures are identified in the text and appendices that follow. In the next section, the objectives and goals are discussed, followed by an irradiation schedule and summary of irradiation conditions, as well as the identification of the irradiation site. The experiment facilities are described in Section 3. Installation and checkout of the test assembly, the test train, and the loop facilities are summarized in Section 4. In Section 5, the operating conditions and control parameters for the U-2 loop, the steam and reflood loops, and the NRU reactor are described or referenced, together with their permissible operating limits. Section 6 contains a sumary of the hazards that have been evaluated during the development of the experiment plan.

\subsection{PROGRAM ORGANIZATION}

This program consists of six experiments using six test assemblies. The first test assembly will be used for the Prototypic Thermal-Hydraulic (PTH) experiment (test series 101 through 145) during a maximum of 45 transient runs; repetitive transients are possible because no fuel failure occurs. Only the first experiment is the subject of all following sections $(2.0, \ldots)$ of th is document.

Subsequent Cladding Material Deformation (CMD) experiments (CMD-200, ...) will each use one test assembly with pressurized test fuel rods to simulate low burnup PWR fue 1, and will be limited to one transient run each (Hann 1980). These tests are each composed of a preconditioning period followed by a pretransient period and a transient period, producing a simulated LOCA and terminating with a desired peak cladding temperature (determined in the PTH experiment) and possibiy, fuel pin failure or cladding ballooning that couid impede subsequent coolant flow. The experiments will be conducted on a twoto four-month frequency, with a nominal schedule as shown in Table 1.1 .

A constant heatup rate and controlled reflood rates and reflood delay times will be used to obtain peak cladding temperatures between $1033 \mathrm{~K}\left(1400^{\circ} \mathrm{F}\right)$ and $>1255 \mathrm{~K}\left(1800^{\circ} \mathrm{F}\right)$. Table 1.2 shows the parameters planned for the fue 1 CMD experiments. Subsequent experiment-operation plans will be provided to 
TABLE 1.1. Experiment Schedule

\begin{tabular}{cc} 
Experiment & Nominal Date Planned \\
\hline PTH-100 & Oct. 1980 \\
CMD-200 & Feb. 1981 \\
CMD-300 & June 1981 \\
CMD-400 & Oct. 1981 \\
CMD-500 & Feb. 1982 \\
CMD-600 & June 1982
\end{tabular}

TABLE 1.2. Conceptua 1 Experiment(a) Plan

\begin{tabular}{|c|c|c|c|c|c|c|c|}
\hline \multirow{2}{*}{$\begin{array}{l}\text { Experiment } \\
\text { Number }\end{array}$} & \multicolumn{2}{|c|}{ Reflood Rate, } & \multirow[t]{2}{*}{$\begin{array}{c}\text { Reflood } \\
\text { Delay Time, }\end{array}$} & & \multicolumn{2}{|c|}{$\begin{array}{c}\text { Maximum } \mathrm{Cl} \text { add ing } \\
\text { Temperature, }\end{array}$} \\
\hline & $\mathrm{m} / \mathrm{s}$ & in. $/ \mathrm{s}$ & & \multicolumn{2}{|c|}{$\begin{array}{c}\text { Maximum } \\
\text { Heating Rate, } \\
\mathrm{K} / \mathrm{s} \text { of } / \mathrm{s}\end{array}$} & & \\
\hline PTH -100 & \multicolumn{3}{|c|}{$-\overline{w a m e t r i c}^{(\mathrm{b})}$} & 8 & 15 & \multicolumn{2}{|c|}{$\overline{\text { parametric }} \overline{(b)}$} \\
\hline CMD-200 & 0.127 & 5 & $32^{(c)}$ & 8 & 15 & 1033 & 1400 \\
\hline CMD -300 & 0.051 & 2 & $12^{(\mathrm{c})}$ & 8 & 15 & 1033 & 1400 \\
\hline CMD -400 & $0.036^{(c)}$ & $1.4(c)$ & 3 & 8 & 15 & 1033 & 1400 \\
\hline CMD -500 & 0.051 & 2 & $25(c)$ & 8 & 15 & 1144 & 1600 \\
\hline CMD-600 & 0.051 & 2 & $40^{(c)}$ & 8 & 15 & 1255 & 1800 \\
\hline
\end{tabular}

(a) In all five CMD experiments, peak rod power will be $1.80 \mathrm{~kW} / \mathrm{m}$ $(0.55 \mathrm{~kW} / \mathrm{ft})$, the system pressure will be $0.27 \mathrm{MPa}(40 \mathrm{psia})$, the inlet reflood temperature will be $326 \mathrm{~K}$ (1270F), subcooling will be $78 \mathrm{~K}$ (1400F) and the initial rod pressure will be $3.1 \mathrm{MPa}(450 \mathrm{psia})$. Fuel rod pressure provides an NRU hot fuel rod operating pressure that simulates a contemporary PWR. Alternate fuel rod pressures may be selected for experiments 5 and 6 , depending upon the results of experiments 2,3 and 4 .

(b) Parametric variables are selected to be prototypic of subsequent experiment thermal-hydraulic operating conditions. Initial fuel rod pressure will be $0.1 \mathrm{MPa}$ (14.7 psia).

(c) Target, final values will be selected from previous experiment results to obtain maximum cladding temperatures.

document changes from this conceptual plan, and to provide current information on the proposed test train assemblies as they are fabricated and assembled for each experiment. 
After each experiment is completed, the test train will be removed to the storage and examination bay area where (at some later time) a remote Disassembly, Examination and Reassembly Machine (DERM) will remove the test assembly shroud and examine the fuel rods. Then, with new central test fuel rods, the test assembly and test train will be reassembled for use in a subsequent experiment.

Responsibilities for various systems used in the experiments are summarized in Table 1.3 .

TABLE 1.3. Experiment Personnel Responsibility

$\begin{array}{ll}\text { Program Manager - Test Director } & \text { C. L. Mohr } \\ \text { Test Operations Leader } & \text { G. E. Russcher } \\ \text { On-Site Representative/Coordinator } & \text { C. L. Wilson } \\ \text { Data Acquisition and Control System } & \text { W. D. Bennett } \\ \text { (DACS) Operation } & \text { R. L. Goodman } \\ & \text { G. M. Hesson } \\ & \text { R. K. Marshall } \\ & \text { L. J. Parchen } \\ \text { Instrumentation Calibration and } & \text { R. A. Scoggin (a) } \\ \text { Operation } & \text { N. J. Wildung } \\ \text { DACS System Programmer } & \text { R. K. Marshall } \\ \text { DERM System Operation } & \text { L. H. Cannon } \\ \text { Test Train Assembly } & \text { L. L. King }\end{array}$

(a) al ternate 


\subsection{EXPERIMENT OBJECTIVES}

The primary objective of this experimental program, which simulates the operating conditions of a PWR fuel rod assembly during a large-break LOCA, is to determine the emergency coolant reflood delay times and the reflood rates that cause fuel failure and to determine the reflood parameters that provide assured failed fuel coolability. A primary goal is to establish the reflood parameters that produce specific peak fuel cladding temperatures in the first experiment so that the fuel failure phenomena can be quantitatively evaluated in subsequent experiments. Another important goal is to record temperature distributions and temperature histories during the LOCA for application to whole core (computer-model) analyses. Power coupling must also be carefully evaluated so that operating conditions and test results can be correlated with other experiment results and related to coolability.

The secondary objective of this program is to establish an in-situ experimental data base that characterizes LOCA conditions and fuel rod failure modes to verify LOCA analys is computer codes with predictive capabilities. Although code development to simulate LOCAs and validate the analyses is outside the scope of th is program, the development of a data handling computer code is a goal. It is necessary to reduce the large volume of data into information for subsequent analytic use and for quick-look reporting during the program.

In the event that fuel cladding ballooning or fuel rod failure does not occur in subsequent cladding materials deformation experiments, the collected data will form a partial basis for LOCA analysis computer code validation. More importantiy, the collected data will serve as the basis for the design of future experiments, and will contribute to establishing the operating conditions before and during the LOCA simulation.

Each experiment is composed of three distinct operating periods: preconditioning, pretransient and transient. The purpose of the first periad is to precondition the fuel structure and fuel/cladding interface. Fuel pellets crack and relocate, partially filling the fuel/cladding gap. Both mechanical and therma 1 forces that are provided are representative of PWR operation 
at a power of $-19.6 \mathrm{~kW} / \mathrm{m}(6 \mathrm{~kW} / \mathrm{ft})$. The objective of the second period is to simulate steam cooled PWR initial LOCA conditions as closely as possible, establishing prototypic decay power and temperature distributions prior to the simulated LOCA transient. The peak cladding temperature is $700 \mathrm{~K}\left(800^{\circ} \mathrm{F}\right)$ and the average linear test fuel rod power is $1.25 \mathrm{~kW} / \mathrm{m}(0.38 \mathrm{~kW} / \mathrm{ft})$. The objective of the third period is to simulate a LOCA using various combinations of reflood rate and reflood delay times to produce specific peak cladding temperatures $1033 \mathrm{~K}, 1144 \mathrm{~K}$, or $1255 \mathrm{~K}\left(1400^{\circ} \mathrm{F}, 1600^{\circ} \mathrm{F}\right.$, or $\left.1800^{\circ} \mathrm{F}\right)$, before the quench occurs.

\subsection{PROTOTYPIC THERMAL-HYDRAULIC EXPERIMENT}

The prototypic thermal-hydraulic (PTH) test series will be conducted during the first of six irradiation intervals and will provide a stepwise transition from we11-controlled, benign LOCA transient conditions to more severe experimental conditions. A1? test fuel rods will be unpressurized to preclude fuel cladding deformation or failure. The PTH series will be conducted during a 7-day period and will provide replicate conditions for the assessment of repeatable heatup and reflood parameters. In addition, the PTH test series will serve as the basis for calibrating the thermal-hydraulic response of the system, predicting high temperature test fuel behavior, and for further refining knowledge of boundary conditions for subsequent cladding materials deformation experiments during which pressurized fuel rod assemblies may deform and rupture.

The primary PTH experiment control variables are reflood delay time and reflood rate. A constant heatup rate minimizes reactor control problems and experimental perturbations. The reflood rates and reflood delay times are used to reverse the fuel rod temperature transient at the desired peak cladding temperature. The proposed operating parameters and schedule for the PTH test series are shown in Table 2.1. Detailed operating conditions are provided in Appendix $C$.

The first experiment is composed of the preconditioning period followed by up to 45 successive pretransient and transient tests. During each, a different parametric combination of the reflood rate and reflood delay time is 
IABLE 2.1. Prototypic(a) Therma\}-Hydraulic Test Series Plan

\begin{tabular}{|c|c|c|c|c|c|c|c|c|}
\hline \multirow{2}{*}{$\begin{array}{l}\text { Test } \\
\text { Day }\end{array}$} & \multirow{2}{*}{$\begin{array}{l}\text { Test } \\
\text { Series } \\
\text { Number }\end{array}$} & \multicolumn{2}{|c|}{ Reflood Rate } & \multirow{2}{*}{$\begin{array}{l}\text { Reflood } \\
\text { Delay } \\
\text { Time, } 5 \\
\end{array}$} & \multicolumn{2}{|c|}{$\begin{array}{l}\text { Maximum } \\
\text { Heating Rate }\end{array}$} & \multicolumn{2}{|c|}{$\begin{array}{l}\text { Predicted (b) } \\
\text { Peak Cladding } \\
\text { Temperature }\end{array}$} \\
\hline & & $\mathrm{m} / \mathrm{s}$ & in. 15 & & & & $K$ & ${ }^{0} \mathrm{~F}$ \\
\hline 2 & 101 & 0.102 & 4.0 & $3^{(c)}$ & 8 & 15 & $<811$ & $<1000$ \\
\hline 2 & 102 & 0.102 & 4.0 & 20 & 8 & 15 & 922 & 1200 \\
\hline 2 & 103 & 0.102 & 4.0 & 29 & 8 & 15 & 977 & 1300 \\
\hline 2 & 104 & 0.102 & 4.0 & 37 & 8 & 15 & 1033 & 1400 \\
\hline 3 & 105 & 0.051 & 2.0 & 7 & 8 & 15 & 1033 & 1400 \\
\hline 3 & 106 & 0.051 & 2.0 & 19 & 8 & 15 & 1088 & 1500 \\
\hline 3 & 107 & 0.051 & 2.0 & 30 & 8 & 15 & 1144 & 1600 \\
\hline 3 & 108 & $0.048^{(d)}$ & 1.9 & $3^{(c)}$ & 8 & 15 & 1033 & 1400 \\
\hline 3 & 109 & 0.038 & 1.5 & 3 & 8 & 15 & 1144 & 1600 \\
\hline 3 & $110^{(\mathrm{g})}$ & $0.038^{(g)}$ & $1.5^{(g)}$ & 11 & 8 & 15 & 1200 & 1700 \\
\hline 3 & 111 & 0.038 & 1.5 & 11 & 8 & 15 & 1200 & 1700 \\
\hline 3 & 112 & 0.076 & 3.0 & 32 & 8 & 15 & 1033 & 1400 \\
\hline 4 & 113 & 0.204 & 8.0 & 39 & 8 & 15 & 1033 & 1400 \\
\hline 4 & $114^{(h)}$ & 0.204 & 8.0 & 46 & 8 & 15 & 1088 & 1500 \\
\hline 4 & 115 & 0.204 & 8.0 & 53 & 8 & 15 & 1144 & 1600 \\
\hline 4 & 116 & $0.254^{(d)}$ & 10.0 & 40 & 8 & 15 & 1033 & 1400 \\
\hline 4 & $117^{(h)}$ & 0.254 & 10.0 & 47 & 8 & 15 & 1088 & 1500 \\
\hline 4 & 118 & 0.254 & 10.0 & 54 & 8 & 15 & 1144 & 1600 \\
\hline 4 & $119^{(9)}$ & $0.155^{(g)}$ & $6.1^{(g)}$ & 52 & 8 & 15 & 1144 & 1600 \\
\hline 4 & 120 & 0.155 & 6.1 & 52 & 8 & 15 & 1144 & 1600 \\
\hline 4 & 121 & 0.076 & 3.0 & 48 & 8 & 15 & 1144 & 1600 \\
\hline 5 & $122^{(g)}$ & $0.076^{(g)}$ & $3.0^{(\mathrm{g})}$ & 53 & 8 & 15 & 1200 & 1700 \\
\hline 5 & 123 & 0.076 & $3.0^{(\mathrm{c})}$ & 53 & 8 & 15 & 1200 & 1700 \\
\hline 5 & $124^{(f)}$ & 0.102 & 4.0 & 37 & 8 & 15 & 1033 & 1400 \\
\hline 5 & 125 & 0.102 & 4.0 & 51 & 8 & 15 & 1144 & 1600 \\
\hline 5 & 126 & 0.102 & 4.0 & 70 & 8 & 15 & 1255 & 1800 \\
\hline 5 & $127^{(f)}$ & 0.102 & 4.0 & 37 & 8 & 15 & 1033 & 1400 \\
\hline 5 & 128 & 0.033 & 1.3 & $3^{(c)}$ & 8 & 15 & 1255 & 1800 \\
\hline
\end{tabular}


TABLE 2.1. contd

\begin{tabular}{|c|c|c|c|c|c|c|c|c|}
\hline \multirow{2}{*}{$\begin{array}{l}\text { Test } \\
\text { Day }\end{array}$} & \multirow{2}{*}{$\begin{array}{l}\text { Test } \\
\text { Series } \\
\text { Number }\end{array}$} & \multicolumn{2}{|c|}{ Reflood Rate } & \multirow{2}{*}{$\begin{array}{l}\text { Reflood } \\
\text { Delay } \\
\text { Time, s }\end{array}$} & \multirow{2}{*}{$\begin{array}{l}\text { Maxim } \\
\text { Heating } \\
\mathrm{K} / \mathrm{s} \\
\end{array}$} & \multirow{2}{*}{$\begin{array}{l}\text { Rum } \\
\text { Rate } \\
0 \mathrm{~F} / \mathrm{s} \\
\end{array}$} & \multicolumn{2}{|c|}{$\begin{array}{l}\text { Predicted }(b) \\
\text { Peak Cladding } \\
\text { Temperature }\end{array}$} \\
\hline & & $\mathrm{m} / \mathrm{s}$ & $i n . / 5$ & & & & $-\mathrm{K}^{-}$ & $\sigma_{F}$ \\
\hline 5 & 129 & $0.038^{(d)}$ & $1.5^{(d)}$ & 20 & 8 & 15 & 1255 & 1800 \\
\hline 5 & $130^{(f)}$ & 0.102 & 4.0 & 37 & 8 & 15 & 1033 & 1400 \\
\hline 5 & 131 & 0.051 & 2.0 & 50 & 8 & 15 & 1255 & 1800 \\
\hline 5 & 132 & $0.204^{(d)}$ & $8.0^{(d)}$ & 71 & 8 & 15 & 1255 & 1800 \\
\hline 6 & $133^{(f)}$ & 0.102 & 4.0 & 37 & 8 & 15 & 1033 & 1400 \\
\hline 6 & $134^{(h)}$ & $0.254^{(d)}$ & $10.0^{(d)}$ & 72 & 8 & 15 & 1255 & 1800 \\
\hline 6 & 135 & $0.028^{(d)}$ & $1.1^{(d)}$ & 3 & 8 & 15 & $1310^{(\mathrm{e})}$ & $1900^{(\mathrm{e})}$ \\
\hline 6 & $136^{(f)}$ & 0.102 & 4.0 & 37 & 8 & 15 & 1033 & 1400 \\
\hline 6 & 137 & $0.038^{(d)}$ & $1.5^{(d)}$ & 32 & 8 & 15 & $1310^{(\mathrm{e})}$ & $1900^{(\mathrm{e})}$ \\
\hline 6 & 138 & $0.051^{(d)}$ & $2.0^{(d)}$ & 60 & 8 & 15 & $1310^{(\mathrm{e})}$ & $1900^{(\mathrm{e})}$ \\
\hline 6 & $139^{(f)}$ & 0.102 & 4.0 & 37 & 8 & 15 & 1033 & 1400 \\
\hline 6 & 140 & $0.102^{(d)}$ & $4.0^{(d)}$ & 76 & 8 & 15 & $1310^{(\mathrm{e})}$ & $1900^{(\mathrm{e})}$ \\
\hline 6 & 141 & $0.204^{(d)}$ & $8.0^{(d)}$ & 77 & 8 & 15 & $1310^{(\mathrm{e})}$ & $1900^{(\mathrm{e})}$ \\
\hline 6 & $142^{(\dagger)}$ & 0.102 & 4.0 & 37 & 8 & 15 & 1033 & 1400 \\
\hline 7 & $143^{(9)}$ & $0.038^{(g)}$ & $1.5^{(d)}$ & $53^{(d)}$ & 8 & 15 & $1310^{(\mathrm{e})}$ & $1900^{(\mathrm{e})}$ \\
\hline 7 & 144 & $0.038^{(d)}$ & $1.5^{(d)}$ & 53 & 8 & 15 & $1310^{(\mathrm{e})}$ & $1900^{(e)}$ \\
\hline 7 & $145^{(f)}$ & 0.102 & 4.0 & 37 & 8 & 15 & 1033 & 1400 \\
\hline
\end{tabular}

(a) Operating conditions are described in Appendix $C$.

(b) Predictions are based on a FLECHT heat transfer coefficient correlation used in the TRUMP heat transfer code. Prediction uncertainty $= \pm 28 \mathrm{~K}\left(50^{\circ} \mathrm{F}\right)$.

(c) Minimum delay time $(<3 s)$ is necessary for the reflood water to arrive at the bottom of the fuel column after steam flow is stopped.

(d) Final value will be selected from earlier tests in this experiment.

(e) Cladding temperature may exceed $1255 \mathrm{~K}\left(1800^{\circ} \mathrm{F}\right)$, based on parameters evaluated from earlier test results. For safety purposes $1310 \mathrm{~K}\left(1900^{\circ} \mathrm{F}\right)$ will be used as the maximum.

(f) Replicate of Test Number 104.

(g) FLECHT data comparison. The first test of each FLECHT data pair uses a fast fill rate up to the $0.306 \mathrm{~m}(1 \mathrm{ft})$ level of the fuel column, then the selected reflood rate. The second test uses a constant reflood rate.

(h) GE data comparison. 
used to produce a specific peak cladding temperature, followed by quenching. Because the fuel rods are not pressurized, they can experience repeated thermal-hydraulic $(\mathrm{TH})$ transients without appreciable deformation or cladding failure.

The sequence to be used in performing the PTH test series is illustrated on Figure 2.1. These tests are consecutively numbered from 1 through 45 to show that experimental data are assembled stepwise as the test operating conditions (reflood rate versus reflood delay time) progress from the region of high confidence in predicted test results to the region of uncertainty. In addition, the danger of aborting the experiment is always present and the possibility of early termination due to instrumentation failure makes it necessary to agressively pursue the uncertain and the unknown regions before the allotted experiment time runs out.

The first test is benign and useful only for calibrating the combined systerns. It is also necessary to evaluate increasing reflood rates to establish the reactivity $\log$ rate effects and the NRU capability to avoid inadvertant trips due to the $\log$ rate 1 imit $(5 \% / \mathrm{s})$. If necessary, the $\log$ rate trip limit will be increased to $10 \% / \mathrm{s}$, or even $15 \% / \mathrm{s}$, to accommodate the tests with high reflood rates. Although peak cladding temperatures of $1310 \mathrm{~K}$ $\left(1900^{\circ} \mathrm{F}\right)$ are noted here, they are identified as such for safety purposes to ensure collection of test data that exceed the test objective temperature of $1255 \mathrm{~K}\left(1800^{\circ} \mathrm{F}\right)$ for fuel cladding during the test transient. 


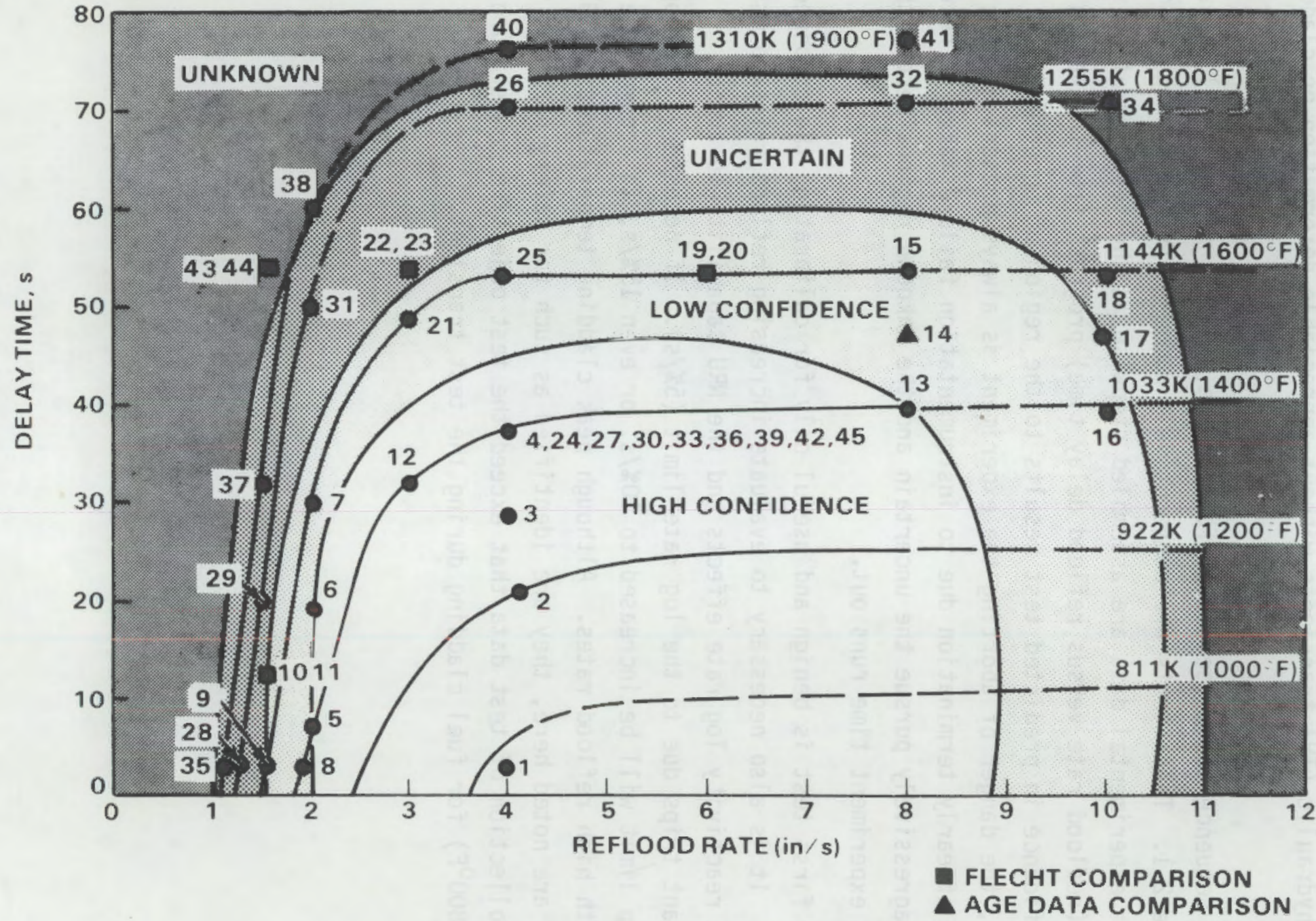

FIGURE 2.1. Schematic of Test Series Operating Conditions and Uncertainty 


\subsection{TEST TRAIN ASSEMBLY, INSTRUMENTATION AND FACILITY DESCRIPTIONS}

This section contains a description of the test train assembly and the instrumentation used for monitoring the flow, temperature, pressure, and neutron flux. The Data Acquisition and Control System (DACS) for retrieving and recording monitored parameters is also described. The pressure tube and test loop provided to supply superheated steam and reflood water are described, including the loop control system. The estimated reactor power required to achieve the test assembly power during each testing period is listed.

\subsection{TEST TRAIN ASSEMBLY}

\subsubsection{Mechanical}

The overall test train assembly length, including closure region, hanger tube and test assembly is $9.18 \mathrm{~m}$ (30 ft $1.5 \mathrm{in.}$.). See Figure 3.1 .

The test assembly fuel bundle consists of a $6 \times 6$ segment from a $17 \times 17$ LWR fuel assembly, with the four corner rods removed for insertion in a shroud, resulting in a basic test array of 32 fuel rods, as shown in Figure 3.2. The outer row of fuel rods, including the corner rods of the next inner ring, will serve as guard heaters during the experiment. The remaining central group of 12 rods will contain 11 test fuel rods and one unfuelled instrument thimble, arranged in a cruciform pattern, as shown in Figure 3.2. The test fuel rods and guard fuel rods will be unpressurized for the first test series (prototypic thermal hydraulic experiment). The bundle is designed to enable reuse of the guard fuel rod heaters in subsequent test trains, and the guard fuel rod assembly can be separated into two sections. The cruciform test fuel rod assembly can also be divided into segments for inspection and also for removal of the instrumented thimble tube. The 11 test fuel rods will be replaced after each experiment by unirradiated fuel rods in subsequent test trains.

A stainless steel shroud will provide the support structure for the fuel bundle and serve as a liner during the experiment. The shroud, which is 


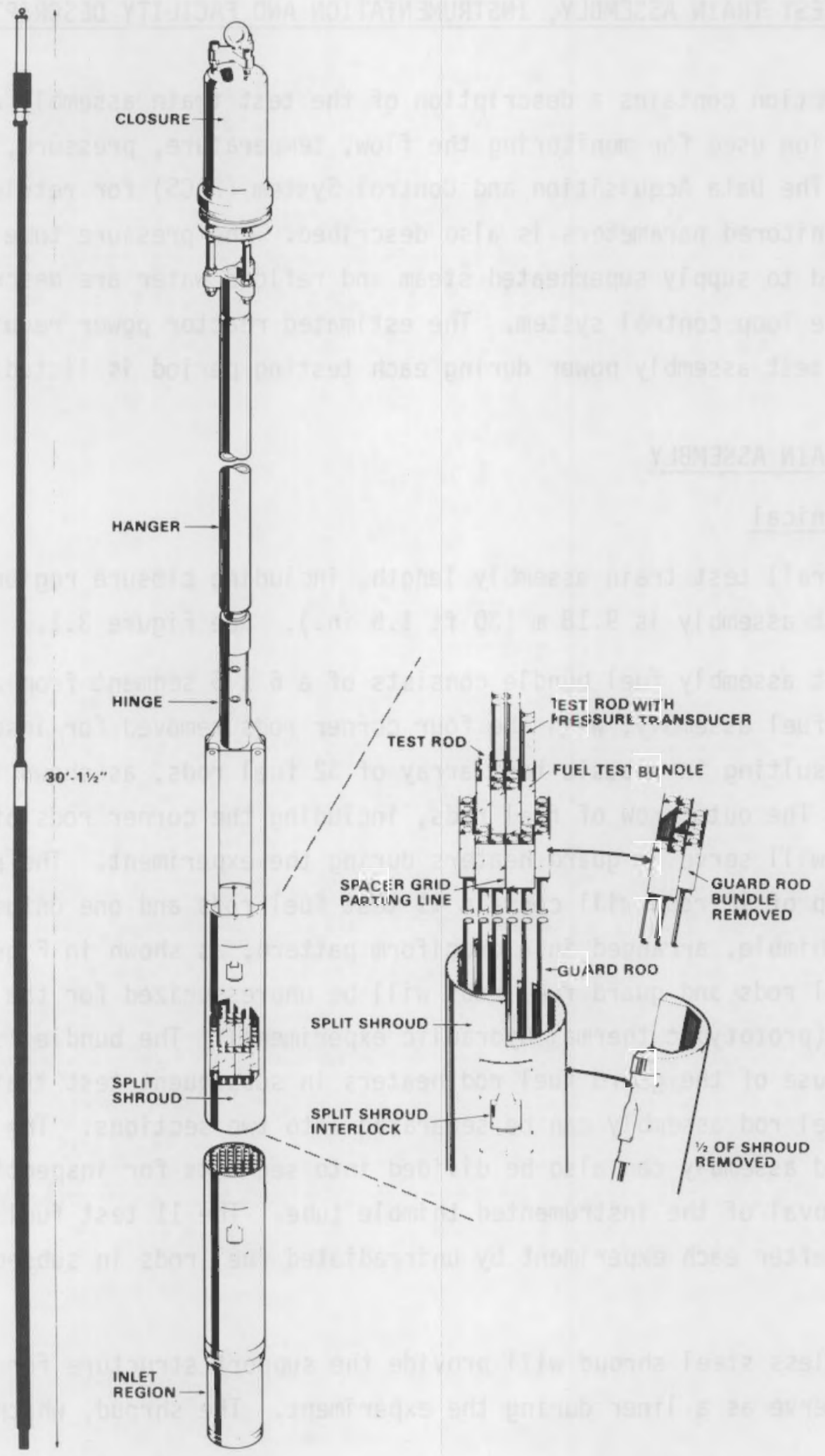

FIGURE 3.1. Schematic of Test Train Assembly 


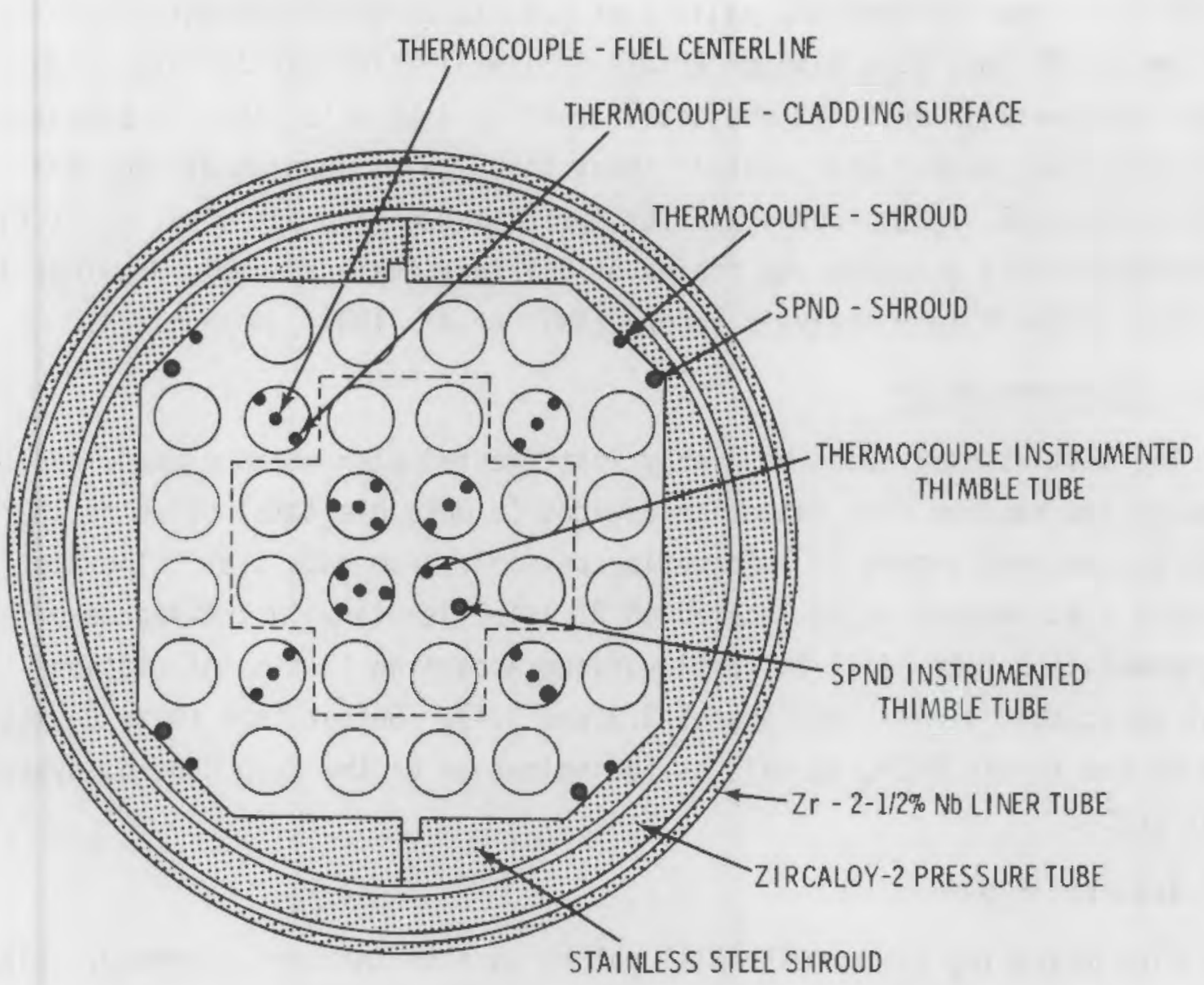

FIGURE 3.2. Cross Section of Test Assemb ly, Pressure Tube and Liner Tube

approximately $4.3 \mathrm{~m}(14 \mathrm{ft})$ long, will consist of two halves split along its length, clamped together at intermittent locations and attached at end fittings.

A hanger tube will suspend the test bundle and shroud from the top closure seal block. The closure seal block will provide the pressure boundary at the top end of the test train, between the test assembly and the loop closure, as well as provide a leak tight penetration for up to 183 instrument leads from the test assembly. A mock-up of the instrument leads in the closure seal block has been built and used for quality control leak testing. 
The fue 1 will consist of $8.27 \mathrm{~mm}(0.325 \mathrm{in}$.$) diameter by 9.53 \mathrm{~mm}$ ( 0.375 in.) long sintered $\mathrm{UO}_{2}$ pellets of $2.9 \mathrm{wt} \% \mathrm{U}-235$ enrichment in a $8.43 \mathrm{~mm}$ ( $0.332 \mathrm{in.})$ ID $\times 0.56 \mathrm{~mm}$ ( 0.022 in.) wall thickness Zircaloy cladding. The overall length of the active fuel is $3.66 \mathrm{~m}(12 \mathrm{ft})$. A complete 31 element fuel bundle will contain about $61.28 \mathrm{~kg}$ of uranium dioxide and $1.84 \mathrm{~kg}$ of U-235. (See Appendix E for specific fuel rod details). A listing of the mechanical drawings and copies of all test train assembly drawings is provided in the Safety Analys is Report (Mohr et al. 1981), Appendix A.

\subsubsection{Instrumentation}

The test assembly will be highly instrumented with steam probes, and temperature and neutron flux detection devices (a possible total of up to 183) to glean the maximum amount of information possible from each test. The test assembly instrumentation is located on 21 axial levels with the degree of instrumentation from level to level varying according to the information required at that level (see Figures 3.3 and 3.4). Output from these devices will be fed to the DACS, as well as to indicators on the Loop Control System Panel (LCS).

\subsubsection{Flow}

Flow measuring instruments will not be part of the test assembly. Flow will be measured by loop instrumentation outside of the reactor core. The standard U-2 loop water flow indications will be used during the preconditioning test period. Separate flow control and indication will be provided by LCS in the test loop for steam flow and for reflood flow during the pretransient and transient test periods. Output will be fed to DACS and LCS panels.

To cool the pressure tube, there will be a small flow bypassing the test section, in the annulus between the outside of the shroud and the inside of the pressure tube. This bypass flow will not be measured during the tests. Out-of-reactor hydraulic tests with the PTH shroud at room temperature have been performed by PNL to show that bypass flow is $4 \%$ of the test section flow. This bypass flow provides adequate cooling for the pressure tube, as well as 


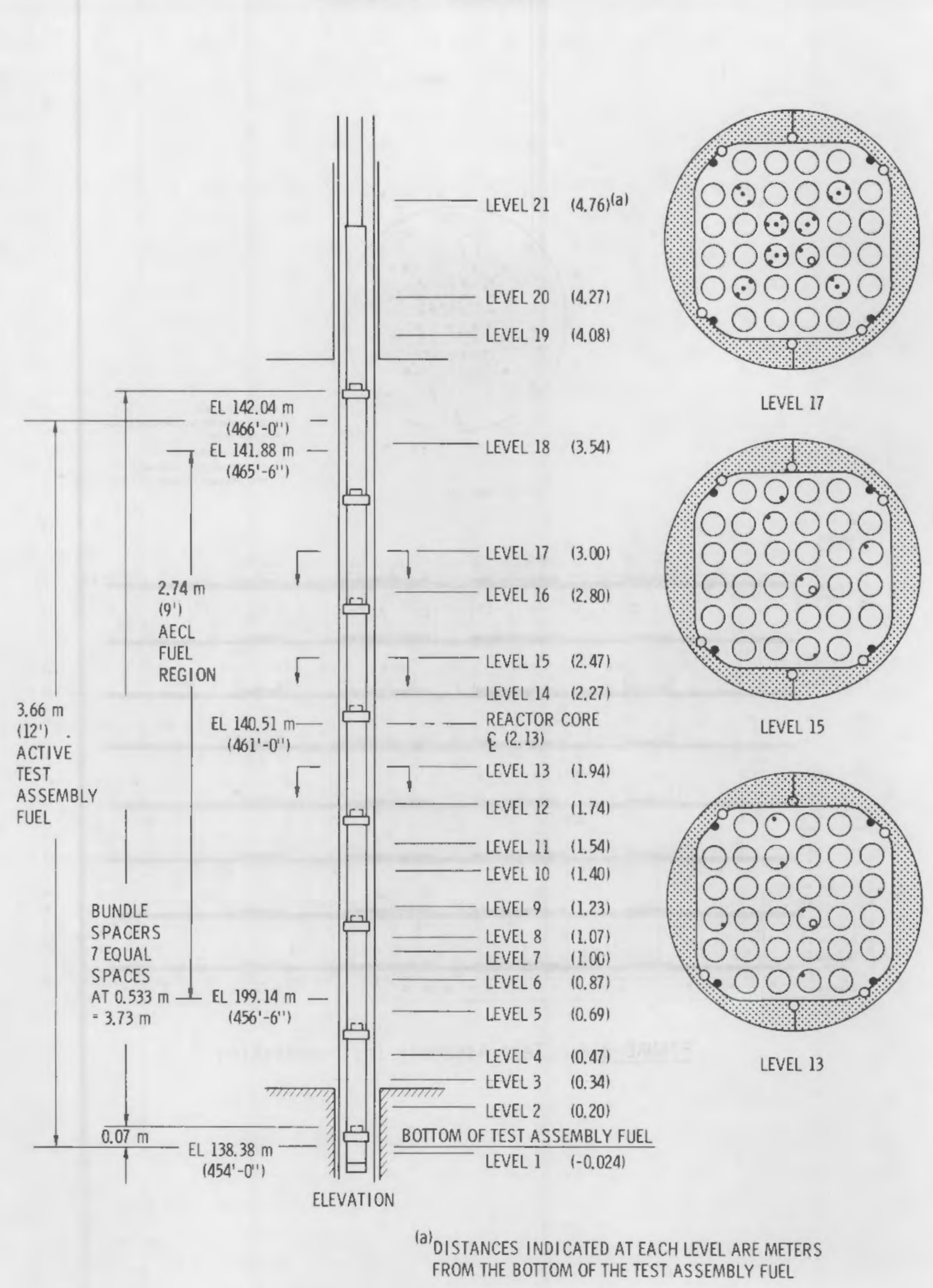

FIGURE 3.3. Test Section Instrument Locations 


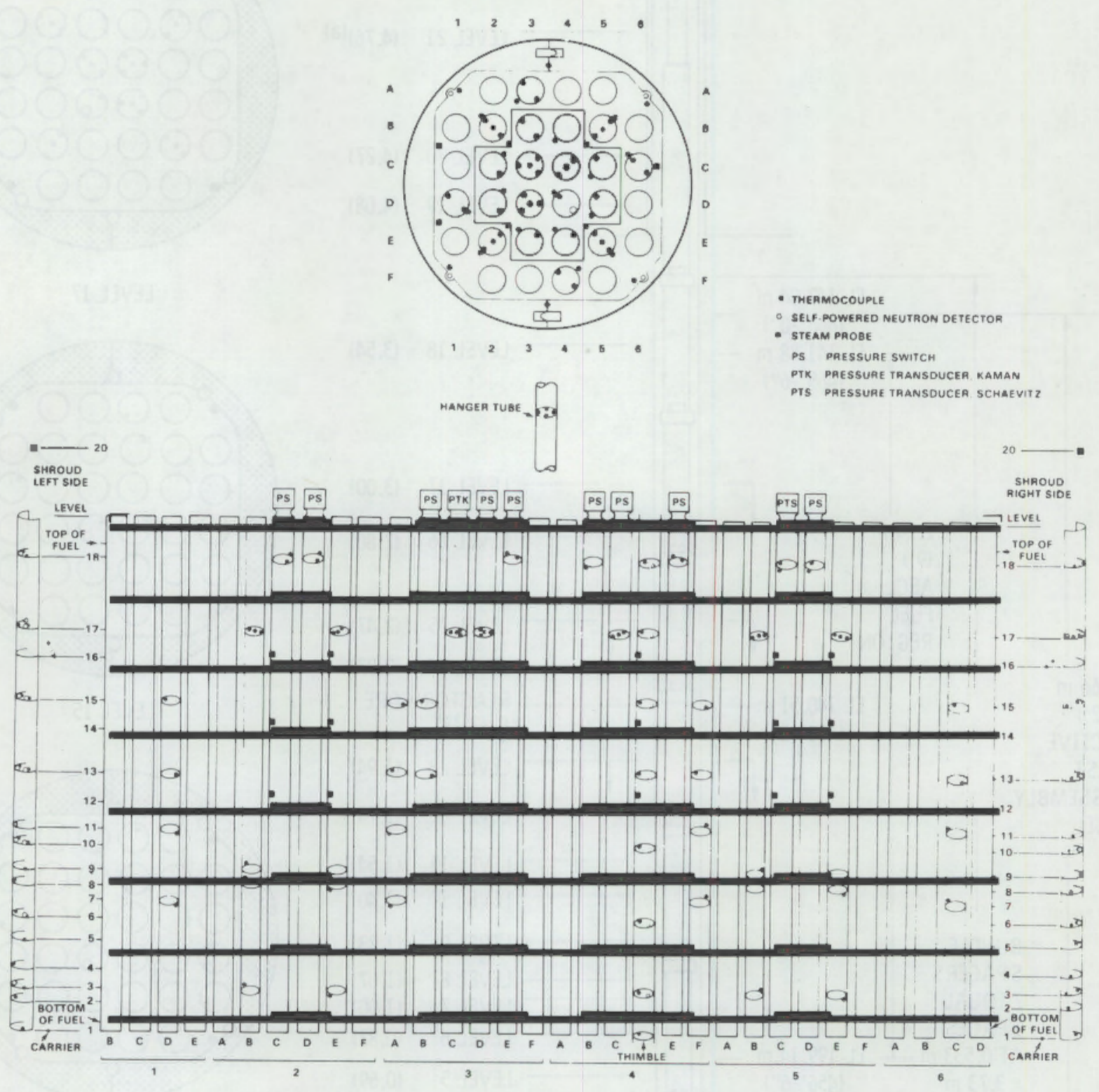

FIGURE 3.4. Test Assembly Instrumentation 
quench front control because $1 \%$ bypass flow was analytically shown to provide sufficient coolant. Subsequent evaluation ${ }^{(a)}$ of the temperature dependence has shown that leakage is expected to increase at test operating temperatures.

Specific flow operating conditions are summarized in Appendix C. Loop calibration requirements are also presented there, in Table C.5.

\subsubsection{Temperature}

All temperature measurements are made with thermocouples (TCS) having Incone 1-600 sheaths and chromel-alumel thermoelements insulated with magnesia. Thermocouple and steam probe locations and numbers are indicated in Table 3.1 and shown in Figure 3.4 .

\section{TABLE 3.1. Test Train Instrumentation}

\begin{tabular}{|c|c|c|c|}
\hline Location & \multicolumn{2}{|c|}{ Instrument } & Function \\
\hline Fuel Rod & & & \\
\hline Fuel Centerline & 7 & & Fuel temperature \\
\hline Cladding ID & 32 & & Fuel/cladding gap temperature \\
\hline Cladding OD & 27 & & Cladding temperature \\
\hline Steam Probes & 18 & & Quench front location \\
\hline Shroud & 38 & 22 & $\begin{array}{l}\text { Temperature, quench front location and } \\
\text { flux distribution }\end{array}$ \\
\hline Thimble Tube & 8 & 7 & Temperature and flux distribution \\
\hline Carrier & 6 & 2 & Coolant temperature and flux distribution \\
\hline Hanger Tube & 4 & - & Pressure tube/coolant temperature \\
\hline TOTAL & 140 & 31 & \\
\hline
\end{tabular}

(a) Memo from G. M. Hesson to G. E. Russcher. September 22, 1980. "Gamma Heat Removal Adequacy for the NRU-LOCA Test Assembly." Pacific Northwest Laboratory, Richland, Washington. 


\subsubsection{Neutron Flux}

Self-powered neutron detectors (SPNDs) with cobalt emitters are distributed radially and axially along the bundle to measure the neutron flux levels during the steady-state and transient operation of the experiment. Total power generated during steady-state operation will be determined by calorimetry. Fission power is obtained by correcting total power for the estimated gamma power component. The axial distribution is determined from the signals of the axially distributed SPNDs.

\subsection{REACTOR POWER ESTIMATE}

The reactor powers required to obtain the test assembly power levels in the test bundles based on estimated reactor loading at the time are summarized in Table 3.2. These values will be re-examined when the reactor loading for the test has been set. See Appendix $C$ for more detailed operating conditions, and acceptable ranges.

TABLE 3.2. Reactor and Test Assembly Power Estimates

\begin{tabular}{|c|c|c|}
\hline Operation & $\begin{array}{c}\text { Assemb ly } \\
\text { Power (MW) }\end{array}$ & $\begin{array}{l}\text { Reactor } \\
\text { Power (MW) }\end{array}$ \\
\hline Precondition & 2.23 & 127 \\
\hline Pretransient and Transient & 0.141 & 8 \\
\hline
\end{tabular}

\subsection{PRESSURE TUBE}

Pressure tube \#50211 for NRU reactor site $L-24$ is designed to meet the requirements of the LOCA simulation test and has no other experimental requirement. (a)

(a) D. T. Nishimura. September 1980. "Proposal. to Install a Zircaloy-2 Pressure Tube \#50211 for the Battelle LOCA Simulation Test." EXP-MAT-14501, Chalk River Nuclear Laboratories, Chalk River, Ontario, Canada. 
The top and bottom fittings and the shroud-bottom seal section are machined from Zircaloy-2 barstock. Tensile specimens were prepared for longitudinal, transverse, and radial ultimate tensile strength (UTS) determination. See Table 3.3.

The upper extension, the in-core tube, and the lower extensions are fabricated from $18 \%$ cold-worked Zircaloy-2. A cold-worked Zircaloy-2 tube long enough to make the pressure tube was not available; therefore, parts of tubes \#502 and \#503 were electron beam welded together. No welds are made in the core region. These tubes are nominal $10.3 \mathrm{~cm}$ (4.07 in.) I0 with $5.08 \mathrm{~mm}$ ( 0.20 in.) wall but they will be gauged and the data included in a CRNL fabrication report.

Using the measured ${ }^{(a)}$ UTS of $422.6 \mathrm{MPa}$ at $575 \mathrm{~K}\left(573^{\circ} \mathrm{F}\right)$ for the Zircaloy-2 barstock and a measured UTS of $347 \mathrm{MPa}$ at $573 \mathrm{~K}\left(572^{\circ} \mathrm{F}\right)$ for the cold worked Zircaloy-2, the safety factors at a nominal wall thickness of $5.08 \mathrm{~mm}(0.20 \mathrm{in.})$ are as noted above ${ }^{(b)}$. Inspection, fabrication and test results (both UTS and burst test data) related to tube assembly \#50211 will be reported in the CRNL fabrication report, to provide justification for experiment operation at $8.62 \mathrm{MPa}(1250 \mathrm{psia})$. The detailed design analysis will be reported in a separate CRNL design report.

TABLE 3.3. Pressure Tube Safety Factors

\begin{tabular}{|c|c|c|c|c|c|}
\hline & Pressure & & mon & Safety Fac & \\
\hline & $M P_{a}(p s i a)$ & $\mathrm{MPa}$ & (ksi) & End Fittings & Tube \\
\hline Operating & $8.62(1250)$ & 90.9 & $(13.17)$ & 4.65 & 3.82 \\
\hline Reactor Trip & (1305) & 94.9 & $(13.76)$ & 4.45 & 3.67 \\
\hline Pressure Relief & (1392) & 101.3 & $(14.69)$ & 4.17 & 3.42 \\
\hline
\end{tabular}

(a) Memo from L. E. J. Mooder to W. L McCrey, September 12, 1980. "First Tests of Simulated Top Flange to Top Extension Tube Joint for Battelle Pressure Tube \#50211." Chalk River Nuclear Laboratories, Chalk River, Ontario, Canada.

(b) 0. T. Nishimura. October 1980. "Proposal to Install a Zircaloy-2 Pressure Tube \#50211 for Batte1le LOCA Simulation Tests." EXP-MAT-14502, Chalk River Nuclear Laboratories, Chalk River, Ontario, Canada. 


\subsection{LOOP IRRADIATION FACILITY}

\subsubsection{Loop Description}

For preconditioning operation, the test train assembly in location L-24 will be connected to the U-2 loop and cooled by pressurized water. Measurement and control of operating conditions within the loop will be provided by U-2 loop instrumentation and equipment. Test train instrumentation signals as we 11 as selected signals from the U-2 loop instrumentation will be connected to the DACS and LCS panels.

Upon completion of the preconditioning period, the L-24 piping will be disconnected from the U-2 loop circuit and connected to the steam/reflood loop circuit. Figure 3.5 illustrates the connect/disconnect arrangement between the two circuits. Detailed description of the circuits and the LCS are provided by Kendrick (1979).

The steam/reflood loop circuit consists basically of two sub-circuits. A steam circuit provides cooling with dry steam during the pretransient period with a quick steam shutoff to initiate the simulation test transient, and a reflood circuit provides an adjustable reflood flow to terminate the transient. The loop circuit is a once-through system with cooling flow from the source, via the test section to the loop catch tank.

During the pretransient period superheated steam from the U-1 loop is fed to the bottom of the test section. When the transient is initiated, the steam is isolated from the test section and dumped to the U-1 condensers.

After an LCS preset reflood delay time, water is introduced to the test section at a predetermined rate from the reflood circuit. This terminates the transient. Reflood water is supplied from accumulators in Room 222, which are pressurized with nitrogen. The rate of reflood flow is controlled by the programed LCS through fast-acting control valves. A standby reflood circuit, which bypasses the normal system, is automatically actuated if failure of the normal reflood circuit occurs; it can also be actuated manually if required. Failure of the standby reflood circuit will also trip the reactor. 
SPI - SPOOL PIECE NO.

PRECONDITIONING CIRCUIT -

SP $\# 1,2,5,7,8,10,11,12,13,14$ REMOVED

SP $\$ 3,4,6,9$ INSTALLED

TRANSIENT CIRCUIT -

SP $13,4,6,9$ REMOVED

SP $\| 1,2,5,7,8,10,11,12,13,14$ INSTALLED

DECONTAMINATION CIRCUIT SAME AS

FOR TRANSIENT EXCEPT SP \#7 REMOVED

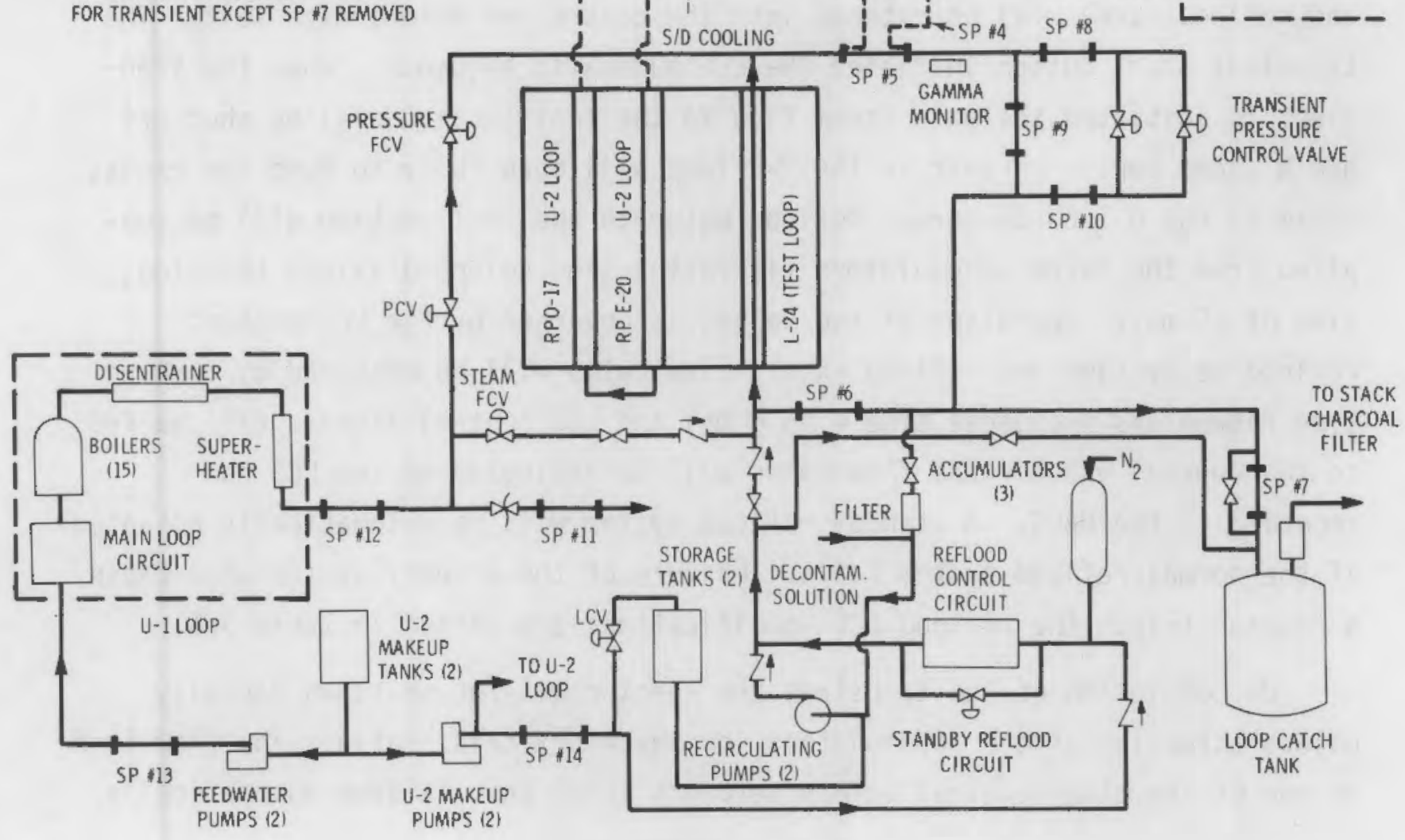

FIGURE 3.5. Schematic of Steam and Reflood Loop System

\subsubsection{Steam and Reflood Loop Control System}

Steam at $0.38 \mathrm{~kg} / \mathrm{s}(3000 \mathrm{1bm} / \mathrm{hr})$ will be provided from the U-1 loop boilers via a flow control valve to maintain the fuel cladding temperature at about $700 \mathrm{~K}\left(800^{\circ} \mathrm{F}\right)$. The steam from the boilers at up to $1.63 \mathrm{MPa}(290 \mathrm{psia})$ will be dried by passing it through the U-1 superheaters. The outlet pressure from the test section will be controlled by the LCS at $0.28 \mathrm{MPa}$ ( $40 \mathrm{psia}$ ) by feeding a small quantity of bypass steam flow to the outlet of the test section. The test section outlet pressure will be regulated by varying the size of the restriction in the outlet line (via air-operated pressure control valves) to maintain a constant test section outlet pressure under varying flow 
conditions. The total steam flow during the pretransient will be steady. The U-1 steam system controls are described in Table 3.4

The transient period will be controlled by the LCS with an automatic sequence programmable controller. The control variables (reflood delay time and reflood rate) will be entered into the controller before each test. The transient start button initiates the LCS automatic sequence. When the transient is initiated the main steam flow to the test section will be shut off and a steam bypass circuit in the U-1 loop will open fully to dump the excess steam to the U-1 condensers. Reflood water to the test section will be supplied from the three accumulators via fast-acting solenoid valves (opening time of $45 \mathrm{~ms}$ ). Operation of the valves is governed by the LCS present reflood delay time and reflood rate. Flow rates will be measured by turbine type flowmeters (response time 4 to $6 \mathrm{~ms}$ ) and LCS control signals will be fed to the control valve. The flow rates will be indicated on the LCS and recorded in the DACS. A standby reflood system will be automatically actuated if the normal reflood system fails. Failure of the standby system will cause a reactor trip. The reflood LCS specifications are listed in Table 3.5.

On completion of the transient the reactor will be shutdown manually unless actuation of the accumulators low inventory trip, reflood low flow trip or one of the other control safety setpoint trips shut it down automatically.

\section{TABLE 3.4. Steam System Controls}

Feed water-- 0.28 to $0.40 \mathrm{~kg} / \mathrm{s}(2200$ to $3200 \mathrm{lbm} / \mathrm{hr}$ ) controlled on steam flow to the test section.

Pressure-- 0 to $2.03 \mathrm{MPa}$ (0 to 290 psia) controlled by modulating boiler heater power in the U-1 loop.

Superheat-- 6 to $22 \mathrm{~K}\left(11^{0}\right.$ to $\left.40 \mathrm{~F}^{\circ}\right)$ controlled by modulating the electrically heated superheaters in the U-1 loop.

Steam flow-- 0.28 to $0.38 \mathrm{~kg} / \mathrm{s}(2200$ to $3000 \mathrm{lbm} / \mathrm{hr})$, to the test section inlet. 0 to $0.025 \mathrm{~kg} / \mathrm{s}(0$ to $198 \mathrm{lbm} / \mathrm{hr}$ ) to the test section outlet. 


\section{TABLE 3.5. Reflood System Controls}

Fast fill rate

up to about $1.07 \mathrm{~kg} / \mathrm{s}(8492 \mathrm{lbm} / \mathrm{hr}$ )

with valve wide open for $2 \mathrm{~s}$

Reflood rate High

up to $0.84 \mathrm{~kg} / \mathrm{s}(6667 \mathrm{lbm} / \mathrm{hr})$

Low

0.04 to $0.19 \mathrm{~kg} / \mathrm{s}$ ( 317 to $1508 \mathrm{lbm} / \mathrm{hr}$ )

Accumulator pressure

3.4 $\mathrm{MPa}$ (493 psia) maximum

Accumulator pressure control

Nitrogen gas pressure through regulating valve

Accumulator heater control

38 to $65^{\circ} \mathrm{C} \pm 3^{\circ} \mathrm{C}$ (100 to $\left.149^{\circ} \mathrm{F}+5{ }^{\circ} \mathrm{F}\right)$ ON-OFF control

Total accumulator capacity $227 \mathrm{~kg}(500 \mathrm{lbm})$

\subsection{DATA ACQUISITION AND CONTROL SYSTEM}

Each instrument signal received (or read) by the DACS will be immediately recorded on magnetic tape and magnetic disk concurrently. While reading and recording sensor data, a low nominal scan rate of 10 samples/s will be used in the steady-state mode, and a high scan rate nominally set at 40 samples/s will be used in the transient mode. For any sensor data recorded by the DACS, any immediate or any historical data in engineering units may be displayed on the DACS control console cathode ray tube, or the computer line printer, or the graphic terminal as hardcopy. The list of instrument sensor data that will be recorded, and which could be displayed by the DACS is given in Table 3.6. A detailed description and operating instructions for DACS are provided by Cannon and Meitzler (1980). 
TABLE 3.6. DACS Monitored Instruments

Reactor Loop

Coolant inlet and outlet temperatures.

Coolant differential and outlet pressures.

U-1 loop coolant flow rate.

Steam flow rate.

Steam pressure.

Steam temperature.

Reflood flow rate.

Reflood coolant temperature.

Test Assembly

Cladding temperatures.

Shroud temperatures.

Local coolant temperatures and differential temperatures.

Local neutron fluxes

Fuel centerline temperatures.

Thimble tube temperatures.

Hanger tube temperature above fuel assembly. 


\subsection{INSTALLATION AND CHECKOUT}

Complimentary and cooperative PNL and CRNL activities will ensure the successful operation of the experiment. The sequence of activities that are planned for the installation and checkout of the first test train assembly are summarized below. The interdependence of these activities is illustrated in Figure 4.1. The upper two lines indicate PNL activities, while the third and fourth lines indicate CRNL activities. Coordination of the various activities is planned with the help of checkpoints $(e . g .,(P-1)$, which require signatures of the designated responsible individuals (e.g., confirm readiness to reassemble the test train, and close the test train shroud).

Similarly, other activities are shown in both serial and parallel configurations identifying their interdependence. Five checkpoints are chosen to emphasize coordinated approvals and the need for concurrence that necessary preparations have been completed by both laboratories before proceeding into subsequent checkout or calibration activities.

A surmary schedule of the cooperative installation and checkout activities planned for both PNL and CRNL staffs is presented in Table 4.1. The activities are numerically ordered to show the sequence of events, whether the activity is solely the responsibility of the PNL installation team (e.g., activity 8 ) or if it requires participation of PNL installation, PNL operations, and CRNL operations representatives (e.g., activity 23).

The first column of activities (in Table 4.1) summarizes PNL installation and checkout of the test train assembly. Column two identifies PNL installation, checkout, and calibration of the experiment. All of these activities use the DACS and the test assembly instrumentation. The third column summarizes activities that are requested of CRNL staff. These activities include a wide variety of both lead and support services needed to make the experiment a success. As part of each activity statement, a section number (e.g., A.2.4) is included to identify where more detail about the activity is summarized--in the following Appendix A and Section 2.4. 
PNL/DACS

\begin{tabular}{l} 
INITIALIZATION \\
DACS CHECKOUT AND CALIBRATION \\
TEST TRAIN \\
\hline CSSSEMBLY \\
CRNLI NRU REACTOR
\end{tabular}
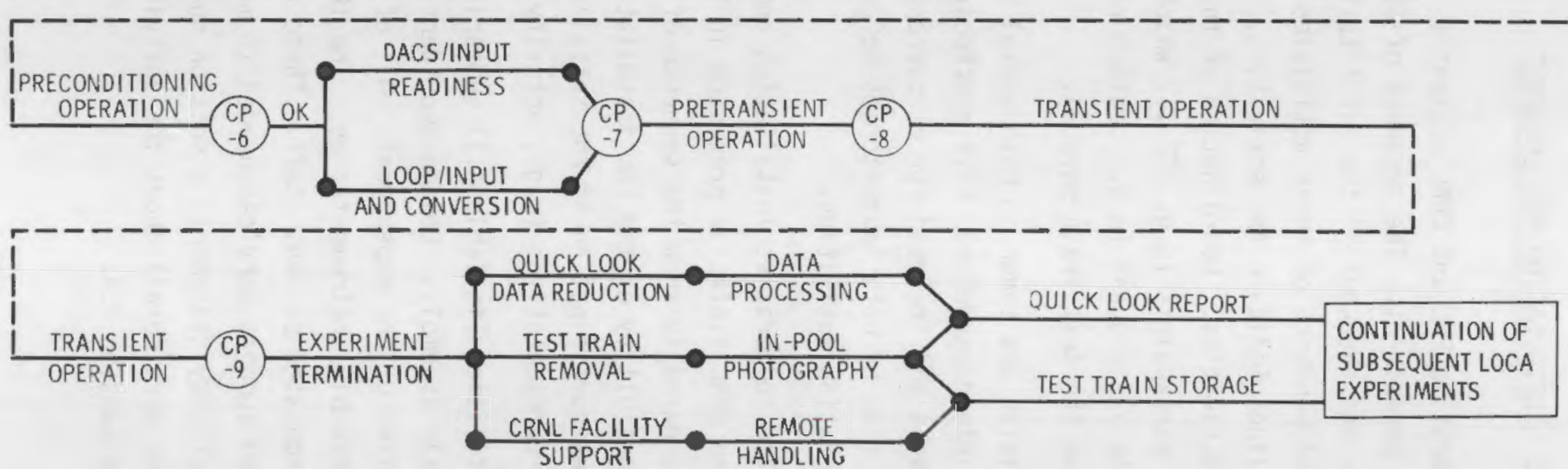

*CP=CHECK POINT FOR SIGNOFFIAPPROVAL

FIGURE 4.1. Activity Flow Chart 


\section{TABLE 4.1. Installation and Checkout Schedule}

Test Irain Absemily Pruentation

2. Open shipping container (A.1.1.1)

3. Remove test train (A.1.1.2)

4. Reconstitute and open shroud (R,1,1.3)

5. Remove fuel bundle and interior packing (A.1.1.4)

6. Visual inspection for shipping damage (A.1.2.1)

7. Measure and record inter-rod spacing at grids (A.1.2.2)

8. Disassentele guard and test fuel rod bundles (A.1.2.3)

9. Check TC attachments and locations (A,1.2.4)

10. Check all wrapped wires, straps and retainers (A.1.2.5)

11. Check shroud seals $(A, 1,2.6)$

12. Confirm readiness to close shroud (A.1.2.7)

13. Signoff Checkpoint 1 in the exper iment log

14. Reassemble test train and install inlet nozzle (A.1.2.8)

15. Install test train in hydraulic test fixture (A.1.3.1)

16. Conduct feed-through seal test (A.1.3.2)

17. Remove test train from hydraulic test fixture (A.1.3.3)

18. Install test tra in on CRNL strongback (A.1.3.4)

19. Conduct pressure tube gauge check (A.1.3.5)

23. Confirm readiness to install test train in U-2 1000 . location L-24 (A.1.4)

24. Signoff checkpoint 2 in experiment $\log (A, 1, A)$

25. Note any handling procedure problems $(A, 1.5$ )

26. Inspect test train installation (A.1.5)
1. Certify tapes and discs $(A, 2,1)$

2. Initiate cold start procedure, record tape and disc IDS

4. Theck TC and SPNO for operability (A.2.4)

5. Format displays (A.2.5)

6. Define special sensors (A.2.6)

7. Measure conductivity of TCs, steam probes and SPMOS
$(A .2 .7)$

9. Ver if y location and identity of TCS, SP s, and SPNDS
$(A, 2,8)$ 10.

12. Confirm readiness to close shroud (A.2.8.3)

13. Signoff Checkpoint 1 in the experiment log

14.

15.

16.

17 .

18.

19. 23. Confirm readiness to install test train in $\mathrm{U}-2$ loop.
location $(-24(\mathrm{~A}, 2,12)$

24. Signoff Checkpoint 2 in experiment $\log ($ A.2.13)

25.

26. Activities

1. Oeliver container to reactor hall, receiving table area

2. Inspect fuel configuration, identification (A.4.1)

3. Support unpacking (A.5.1)

4. Install and checkout loop instrumentation (A.4.2)

5. Provide reactor core initial conditions and description
$(A, 4.3)$

7.

10.

11.

12.

13.

14.

15. Provide support services (A.5.1)

16.

17.

18. Provide support services (A.5.2)

19. Provide pressure tube gauge (A.4.4, A.5.3.1)

23. Confirm readiness to install test train in U-2 loop,

24. Signoff Checkpoint 2 in exper iment $\log (A, 4,6)$

25. Install test train in location L-24 (A.4.7) 
TABLE 4.1. (contd)

Test Train Assemply

27. Record in-reactor or ientation (A.1.5)

28. Assist installation of $100 \mathrm{p}$ closure seal for $\mathrm{U}-2$ stump

29. Torque bolts on stump body clamp ring and feed-through
clamp ring $(A .1 .6)$

30. Assist leak testing loop closure seal (A.1.7)

31. Confirm seal acceptance $(A, 1.7)$

32. Signoff $\mathrm{CP}_{-3}$ in experiment $\log (\mathbf{A}, 1.7)$

35. Assist loop closure head insulation (A.3.1)

36. Return shipping container, etc. to PNL (A.3.2)

$$
\begin{gathered}
\text { Pre } \\
\text { QACS/Instrumentation }
\end{gathered}
$$

$$
27 .
$$

29.

30.

31.

32.

33. Install 3 TCS to monitor closure head temp. (A.3.3)

34. Connect instruientation cables to connectors-ground to
closure head $(A, 3.4)$

35. Install TC to monitor cannon connector temp. (A.3.5)

36. Install cannon connector auxiliary head cooling blower
(A.3.6)

37.

38. Receive and store $100 \mathrm{p}$ calibration data $(A, 3.7)$ 40. Scan DACS, print, reviey, advise test dir. of
instrument status
$(A .3 .7)$

41. Establish and verify trip circuit and forced transient

42. Input trip setpoints for preconditioning operations
$(A, 3,3)$

43. Signoff Checkpoint 4 in the exper iment 109

44. Record calibration constants, units and data
correlated $W / R E D A C E(A .3 .12)$

45. Scan DACS, print, review, advise test dir. of
instrument status $(A, 3.13)$ 46.

47. Scan Dacs, print, review advise test dir. of B. Confirm readiness to proceed with precond it ion ing
operation $(A .3 .15)$

49. Signoff Checkpoint 5 in experiment $\log$ (A.3.1.6)
Com

27.

28. Install loop top closure seal $(\mathbf{A , 4 . 7 )}$

29. Provide support services (A.4.7)

30. Leak test loop top closure seal (A.4.B)

31. Confirm seal acceptance (A.4.9)

32. Signoff $C P-3$ in exper iment $\log (A, 4,9)$

33. Provide support services (A.5.4)

34. Assist cable install ation (A.5.4)

35. Install loop elosure head insulation (A.5.5)

36. Provide support services (A.5.4)

37. Calibrate loop control, $U-1$ and $U-2$ instruments

. Provide calibration data to oACS (A,4.11)

39. Fill U-2 loop with mater, static at equiliorium
shutdown NaU temp. $(A, 4,12)$ 40.

41. Establish and verify trip circuit and forced iransient

42. Input tr ip setpoints for precond itioning operations
$(A .4 .15)$

43. Signoff Checkpoint 4 in the exper iment log

44. Circulate U-2 loop water at $5 \mathrm{~kg} / \mathrm{s}(83 \mathrm{gpm})(A, 4.16)$

45.

46. Maintain circulation rate, pressurize and heat water to 8.62 . (1250 psia) $400 \mathrm{~K}(275 \mathrm{~F})(\mathrm{A} .4 .17$ and

47. Hold or shutdown c1rculation/heat-prepare for reactor

48. Confirm readiness to proceed with preconditioning
operation $(A, 4.18)$

49. Signoff Checkpoint 5 in exper iment $\log (A, 4,19)$ 


\subsection{EXPERIMENT OPERATIONS}

Cooperative and complimentary activities by PNL. and CRNL staffs are also needed during the experiment operation. The interdependence of these activities is shown in Figure 4.1, where the lower two-thirds of the figure depicts the preconditioning, pretransient and transient periods of the experiment. Parallel activity lines illustrate concurrent PNL and CRNL activities, and checkpoints illustrate when specific concurrence is needed between PNL and CRNL before continuation of the experiment.

A summary schedule in Table 5.1 shows the experiment operations for both OACS/instrumentation and NRU reactor/loops control, and are briefly identified in a schedule that is numerically ordered to show the sequence of events. The laboratory responsibility for lead and/or support activities and the location (appendix and section) for more detailed information are both provided below.

The first column of Table 5.1 identifies PNL experiment operation activities and the second column identifies CRNL activities. These include a wide variety of tasks, reactor and loop control, instrument calibration, test operation and facility support. Many activities are cooperative, and are the bas is of a successful experiment. 


\section{TABLE 5.1. Experiment Operations}

PNL AACS/instrumentation

50.

51. Set DACS in steady-state mode - scan, print and review data - advise to proceed (B.1.1)

52. Initialize all SPND amplifiers (B.1.2)

53. Scan DACS data, print, review - advise TD to proceed (B.1.3)

54.

55. Scan DACS data - print, review - advise TD to proceed (B.1.4)

56.

57. Scan OACS data - print, review - advise to to proceed (B.1.5)

58.

59. Scan DACS data - print, review - advise TO (6.1.6)

60. Conditionally trip the NRU reactor $(B, 1,7)$

61. Verify that all required preconditioning data have been collected (B.1.8)

62. Scan DACS, print, review - advise TD to trip for shutdown (B.1.8)

63. Return DACS to steady-state mode - scan and record hourly (B.1.9)

64. Prepare instrumentation for loop conversion (B.1.10)

65. Confirm readiness to proceed with loop conversion (B.1.11)

66. Signoff $C P-6$ in experiment $\log (8,1.12)$

67. Continue DACS in steady-state mode - scan and record hourly (B.1.9)

68. Install new DACS tape and discs, DACS in idle mode (B.2.1)

69. With OACS in steady-state, record calibration changes, units, REDACE results, controlled parameters $(B .2 .2)$

70. Adjust SPND amplifiers if required $(8,2.3)$

71. Input loop conversion factors and units (8.2.2)

72. Input trip setpoints for pretransient operation (B.2.4)

73. Scan DACS data, print, review - advise tD of instrumentation status (B.2.5)

74. Check all loop control parameter settings (8.2.6)

75. Confirm readiness to begin pretransient operation $(B .2 .6)$

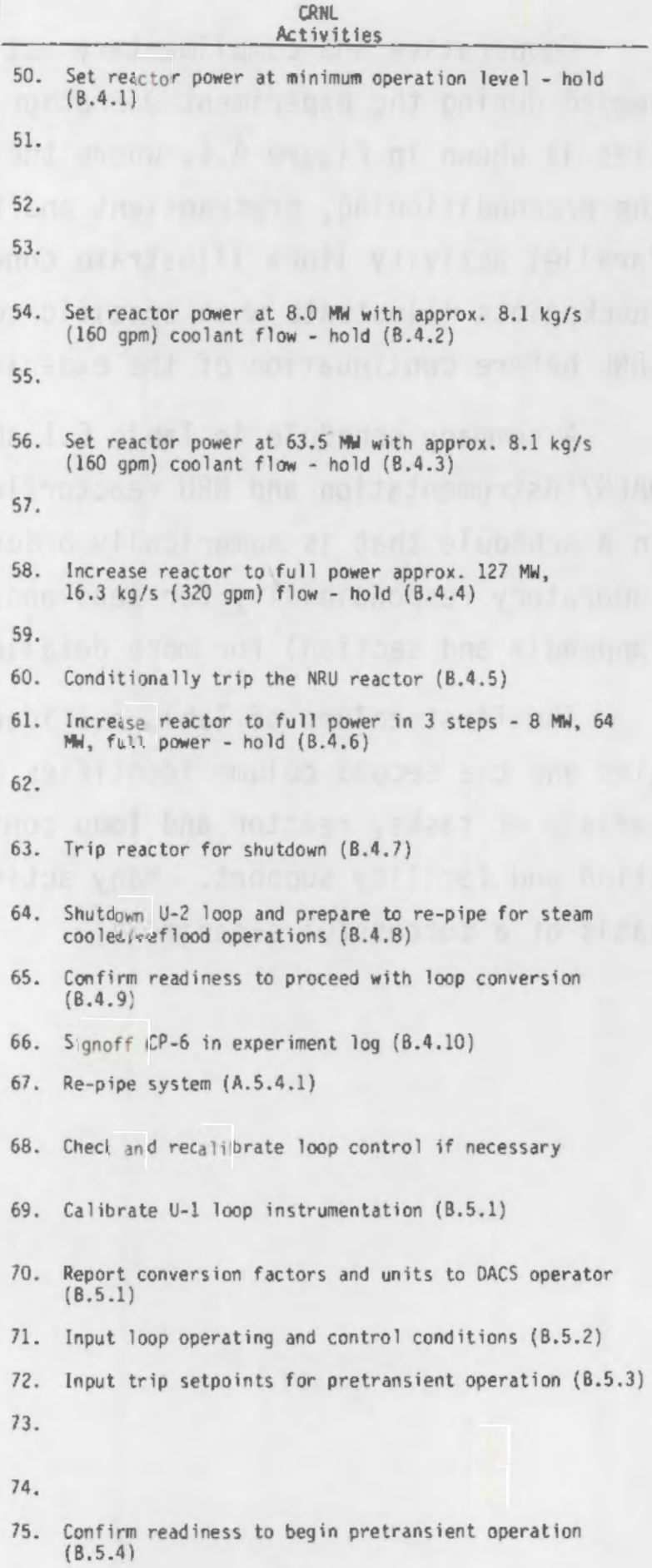

50. Set reactor power at minimum operation level - hold (B.4.1)

51.

52.

53.

54. Set reactor power at $8.0 \mathrm{~m}$ with approx. $8.1 \mathrm{~kg} / \mathrm{s}$ (160 gpm) coolant flow - hold (B.4.2)

55.

56. Set reactor power at 63.5 with approx. $8.1 \mathrm{~kg} / \mathrm{s}$ (160 gpm) coolant flow - hold $(8.4 .3)$

57.

58. Increase reactor to full power approx. $127 \mathrm{MW}$, $16.3 \mathrm{~kg} / \mathrm{s}(320 \mathrm{gpm})$ flow - hold $(3.4 .4)$

59.

60. Conditionally trip the NRU reactor $(B .4 .5)$

61. Increase reactor to full power in 3 steps $-8 \mathrm{MN}, 64$ Mu, full power - hold (B.4.6)

62.

63. Trip reactor for shutdown $(B .4 .7)$

64. Shutdown U-2 $100 p$ and prepare to re-pipe for steam cooled/reflood operations (B.4.8)

65. Confirm readiness to proceed with loop conversion (B.4.9)

66. Signoff $C P-6$ in experiment $\log (B .4 .10)$

67. Re-pipe system (A.5.4.1)

68. Check and recalibrate loop control if necessary

69. Calibrate U-1 loop instrumentation (B.5.1)

70. Report conversion factors and units to DACS operator (B.5.1)

71. Input loop operating and control conditions $(8.5 .2)$

72. Input trip setpoints for pretransient operation $(8.5 .3)$

73.

74.

75. Confirm readiness to begin pretransient operation $(8.5 .4)$ 


\section{TABLE 5.1. (cont inued)}

\section{aAcs/instrumentation}

76. Signoff $\mathrm{CP}-7$ in experiment $\log (B .2 .6)$

77. Scan DACS data, print, review - advise TO to proceed (B.2.7)

78. Scan DACS data, print, review (B.2.8)

79. Confirm reactor power/steam flow rate is acceptable based on fuel cladding temperature and the acceptable range cited in Appendix $C$, Table $C .2(B .2 .9)$

80. Input transient trip setpoints (B.2.10)

81. Confirm readiness to begin transient operation $(8.2 .11)$

82. Signoff $C P-8$ in experiment $\log (B .2 .12)$

83. Switch DACS to transient mode 20s before "begin transient" (B.2.13)

84. Issue "Begin Transient" directive (B.2.13)

85. Issue shutdom directive when quench is complete (B.3.1)

86. Record reflood coolant volume used (B.3.2)

87.

88. Reset transient forcing signal to "O" (B.3.3)

89. Return DACS to steady-state mode - print, review preliminary results (B.3.4)

90. Historically scan selected channels to evaluate peak temperature and quench $t$ imes $\{B .3 .5\}$

91. Confirm transient test complete and ready for drain (B.3.6)

92. Signoff $C P-9$ in experiment $\log (B .3 .6)$

93. Leave DACS in steady-state mode - scan and record post transient hourly (B.3.7)

94. Print. DACS system $\log (B .3 .7)$

95. Return DACS to idle mode (B.3.8)

96. Check DACS calibration (B.3.8)

97. Terminate current test on DACS (B.3.9)

98. Create tape copies of data as time permits

99. Return to Step 68 and repeat until all tests in series are completed

100. After last test series is completed, direct reactor operator to shutdown for test train removal

101. Disconnect cables, seal and secure pigtail connectors.

102. If required, realign attachment eye to mate with $\mathrm{J}$ Rod Flask attachment grapple.

103.

104. Coordinate $v$ isual/photo inspection
CRAN Activities

76. Signoff $\mathrm{CP}-7$ in experiment $\log$

77. Set reactor power at 2.0 with steam flow approx. $0.095 \mathrm{~kg} / \mathrm{s}(750 \mathrm{lbm} / \mathrm{hr})$ - hold $(B .5 .3)$

78. Set reactor power at 8.0 with steam flow approx. $0.378 \mathrm{~kg} / \mathrm{s}(3000 \mathrm{lbm} / \mathrm{hr})$ - hold $(B .5 .6)$

79. Confirm reactor power/steam flow acceptability based on peak fuel cladding temp. and test assembly power. Table C.2 (B.5.7)

80. Input transient trip setpoints $(B .5 .8)$

81. Confirm readiness to begin transient operation (B.5.9)

82. Signoff $C P-8$ in experiment $\log (8.5 .10)$

83. Confirm (electrical interlock)

84. Initiate transient operation (B.2.13)

85

86. Shutdown reactor on cormand (B.6.2)

87.

88. Verify that the transient forcing signal is " 0 " $(B, 6,3)$

89. Monitor reflood coolant volume used and report to DACS operator $(B, 6.1)$

90.

91.

92. Signoff CP-9 in experiment $\log (\mathbf{B} .6 .4)$

93. Begin preparations for next test $(B .6 .4)$

94. Orain loop to prepare for next test (B.6.5)

95.

96. Check LCS calibration

97.

98.

99. Return to Step 68 and repeat until all tests in series are completed (B.6.5)

100. Shutdown reactor and prepare to remove test train (A.5.5)

101

102. Using $\mathrm{J}$ rod Flask, transfer test train from $L-24$ to transfer can and fuel transfer elevator (B.7.2)

103. Transport test train in transfer can to examination bay storage area - remove transfer can (B.7.3, B.7.4.1, B.7.4.2)

104. Visual/photo inspection of test train (B.7.4.3)

105. Transfer test train to interim storage bay location (B.7.4.4) 



\subsection{HAZARDS REVIEW}

\subsection{NORMAL REFLOOD EFFECTIVENESS}

The largest body of information bearing on fuel rewetting or quench is that of the Westinghouse FLECHT experimental series. Summary reports (e.g., Cadek et al. 1972) describe the experiments and results that cover the same range of reflood rates as in the tests of this experiment. The FLECHT tests used a $10 \times 10$ array of $3.66 \mathrm{~m}$ long electrically heated elements as a representation of a $15 \times 15$ element bundle. In general steam caused by vigorous boiling of the reflood water in the lower sections of the fuel subsequently resulted in some cooling to the upper sections, and the temperature rise began to decrease. The temperature then peaked and began decreasing before the quench front arrived at the upper sections of the fuel. The tests showed the adequacy of reflooding to cool the fuel elements, and provided the basis of correlations that quantitatively describe its occurrence. The basic differences between the tests are listed in Table 6.1.

In addition, pretransient steam cooling in the PTH-LOCA simulation experiment provides a different initial temperature distribution.

The PTH test series should show as effective rewetting of the test assembly as the FLECHT tests; however, the timing of the temperature increase,

TABLE 6.1. Difference Between the LOCA Simulation Experiment and the FLECHT Tests

\begin{tabular}{|c|c|c|}
\hline Item & $\begin{array}{c}\text { LOCA } \\
\text { Simulation }\end{array}$ & FLECHT \\
\hline Heat source & Nuclear & Electrical \\
\hline Fuel rod cladding & Zircaloy & Stainless steel \\
\hline Peak-to-average axial power distribution & 1.51 & 1.66 \\
\hline Number of fuel rods (array) & $31(6 \times 6)$ & $100(10 \times 10)$ \\
\hline
\end{tabular}


turnaround and quench may be different. The stepwise plan for experiment operation described in Section 2.0 should preclude any problem of excessive temperatures up to the time quench occurs.

\subsection{EXPECTED AND HYPOTHETICAL RADIOACTIVITY RELEASES}

Because it is unpressurized, no fuel cladding failure is anticipated during the thermal-hydraulic test and therefore, no radioactivity release is expected. However, for a hypothetical accident with low burnup fuel rods in these tests, the quantity of iodines and noble gases that could be released is less than $1 \%$ of the fission product inventory (Lorenz, Hobson and Parker 1971; Hastings and Notley 1979). Any radioactive release would be vented to the atmosphere via the loop catch tank vent and reactor stack. An impregnated activated charcoal filter installed on the loop catch tank vent line would reduce any radioiodines released to an acceptable level, (see Axford et al. 1980). Before each test, the charcoal filter will be tested to ensure that its efficiency is no lower than $99.5 \%$. HEPA filters are installed in the vent line upstream from the charcoal filter. An in-line cooler condenses any moisture in the air. A continuous flow of dry air will be drawn through the charcoal while it is being used, to further ensure dry conditions.

The fission product inventory that could be available in a hypothetical accident, and the amount that could be released into the atmosphere are shown in Table 6.2. The figures shown are conservative because:
a) It is assumed 1\% of fission product inventory is released, while the actual release should be less than $1 \%$.
b) It is assumed that all 31 fuel rods fail; however none are expected to fail.
c) There is no allowance for any plateout. 
TABLE 6.2. Estimated Radioactive Releases for a Hypothetical Accident

\begin{tabular}{|c|c|c|c|}
\hline Fission Product & Inventory & Available & Releasable \\
\hline & 61 & & $0.061^{(a)}$ \\
\hline Noble Gases ( $\mathrm{C} i \mathrm{MeV}$ ) & 12370 & 123.7 & 123.7 \\
\hline
\end{tabular}

(a) Charcoal filters in the vent line will reduce release by $<99$

The iodine release represents about $0.5 \%$ of the week ly limit for I-131. The noble gas release is insignificant when compared with the derived release limit.

A strainer is installed at the bottom of the test section to retain any fuel fragments or debris released. If any fuel fragments are carried over to the catch tank and the normal catch tank ion exchange system cannot clean up the activity, the fuel fragments would be removed by dissolving them and then storing the resulting solution in tanks until the CRNL Waste Treatment Center is operational. The volume of liquid involved would be quite small, and special tanks are available for this purpose. This procedure has been discussed with the CRNL Environmental Authority and is acceptable to them.

If the piping needs to be decontaminated after a test, provision has been made to recirculate decontamination solution through the test section and piping, as shown in Figure 3.5. The decontamination solution would be transferred to the catch tanks in Room 110, and then to special tanks before processing at the CRNL Waste Treatment Center.

Charcoal filters are installed on the loop catch tank vent line to the NRU reactor stack to retain any radioiodides released during an accident.

\subsection{LOSS OF COOLANT DURING PRECONDITIONING}

In this postulated accident, the concern is that during the preconditioning period when the NRU reactor is at full power and the test section is connected to the U-2 loop, a sudden loss of coolant could produce a reactivity insertion of $<3 \mathrm{mk}$ (Heaberlin et al. 1979). However, the resulting increase in 
reactivity is similar to a case already addressed $(a)$ for U-2 loop, but much less severe (6 mk). The PTH experiment will have only one test section instead of two, and the fuel will be a low burnup fuel of approximately $0.05 \mathrm{MWh} / \mathrm{kg}$ versus up to $200 \mathrm{MWh} / \mathrm{kg}$ burnups for an average reactor test fuel string. The operating period will be of short duration and closely monitored. The normal loop automatic emergency cooling system will be in service during preconditioning operation of this experiment.

\subsection{LOSS OF REFLOOD AND TRIP}

In this postulated accident, it is assumed that a high temperature transient test is underway and that normal reflood does not come on as scheduled $60 \mathrm{~s}$ after initiation of the transient, and that another $20 \mathrm{~s}$ passes before the reactor trips. It is noted that in fact the reactor would trip on failure of standby reflood. Standby cooling does not come on. The total power will drop at a rate slightly greater than the measured neutron decay as illustrated in Figure 6.1 (Mohr et al. 1980).

Test assembly temperatures calculated using the TRUMP code are illustrated in Figure 6.2 (Mohr et al. 1980). The clad temperature stops increasing $20 \mathrm{~s}$ after the trip and a peak of less than $1366 \mathrm{~K}\left(2000^{\circ} \mathrm{F}\right)$ is reached. Heat is removed through the shroud and pressure tube to the $\mathrm{D}_{2} \mathrm{O}$ moderator. The shroud and pressure-tube temperatures in the area of the fuel will continue to increase 8 to 10 min after the reactor trip, peaking at about $808 \mathrm{~K}$ $\left(995^{\circ} \mathrm{F}\right)$ and $533 \mathrm{~K}\left(500^{\circ} \mathrm{F}\right)$, respectively. The corresponding peak fuel centerline temperature will be about $1383 \mathrm{~K}\left(2030^{\circ} \mathrm{F}\right)$.

With no steam flow as a result of no reflood, the calculated pressure tube temperature above the fuel will drop off as is illustrated in Figure 6.3 . The initial pressure tube temperature of $644 \mathrm{~K}\left(700^{\circ} \mathrm{F}\right.$ ) (used in the calculation) is conservatively high, since it corresponds to an average fuel rod power approximately $20 \%$ higher than that expected in the LOCA-PTH test.

(a) J. A. Morrison et al. 1964. "A Safety and Hazards Review of the NRU Reactor." IOI-260, Addendum 10, Chalk River Nuclear Laboratories, Chalk River, Ontario, Canada. 


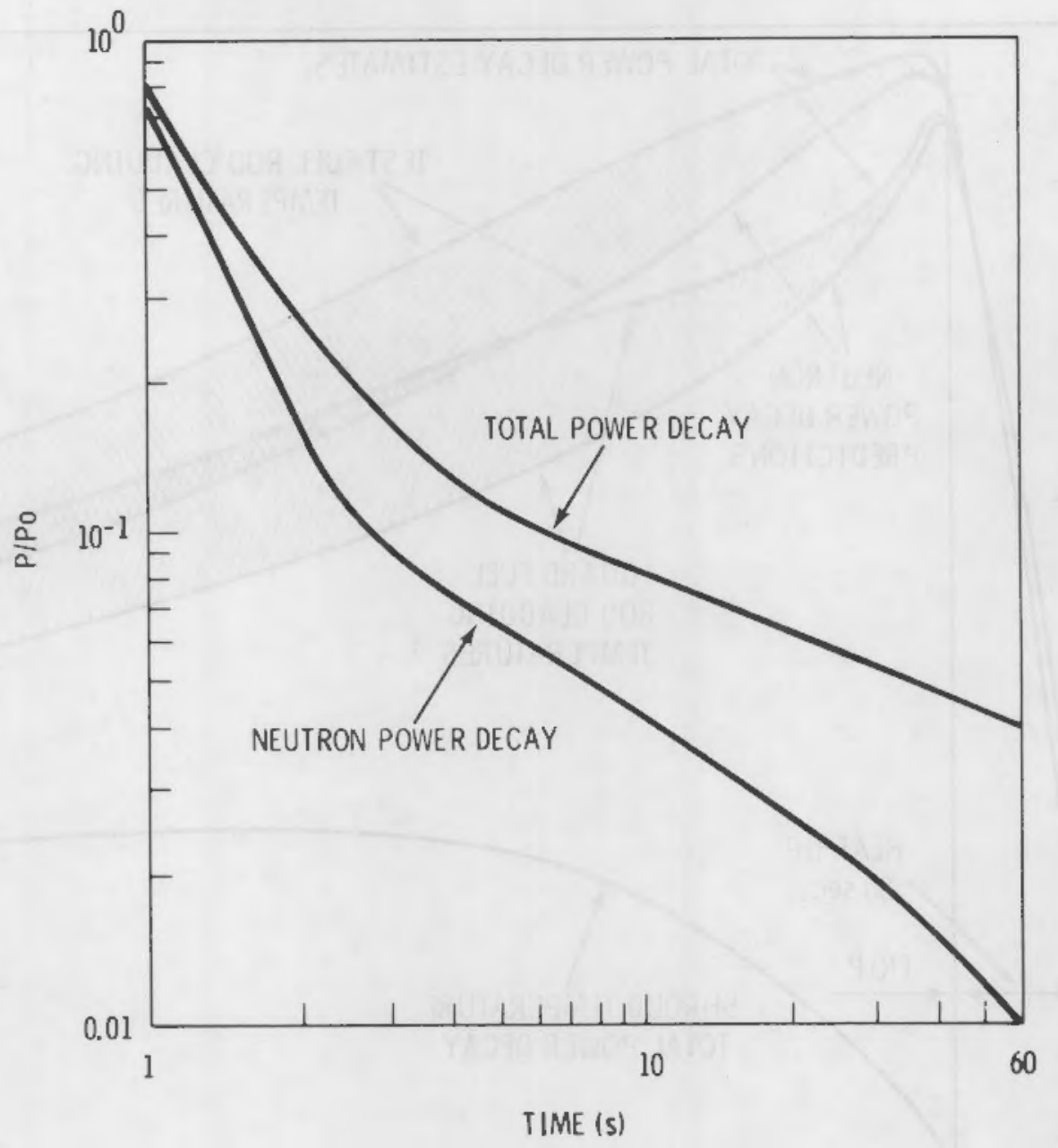

FIGURE 6.1. NRU Power Decay After Trip

\subsection{LOSS OF REFLOOD AND STANDBY REFLOOD INITIATED}

In th is postulated accident, it is assumed that normal reflood does not come on as scheduled, $60 \mathrm{~s}$ after initiation of the transient, and that standby reflood is introduced at a rate of $10 \mathrm{~cm} / \mathrm{s}(4 \mathrm{in.} / \mathrm{s}$ ) after a $20-\mathrm{s}$ time delay, with no reactor trip. Here again, it is noted that in fact the reactor will trip at $60 \mathrm{~s}$ if standby reflood fails. Data from FLECHT tests (see Figure 6.4) show that for a reflood rate of $10 \mathrm{~cm} / \mathrm{s}(4 \mathrm{in.} / \mathrm{s})$ clad temperatures will rise 55 to $80 \mathrm{~K}\left(100^{\circ}\right.$ to $\left.145^{\circ} \mathrm{F}\right)$. If standby cooling is introduced at the $80-\mathrm{s}$ point in Figure 6.2 a peak clad temperature of $1388 \mathrm{~K}\left(2040^{\circ} \mathrm{F}\right)$ will be reached. The corresponding fuel centerline temperature will be about $1400 \mathrm{~K}\left(2060^{\circ} \mathrm{F}\right)$. The FLECHT test data also show that for reflood rates similar to this, steam 


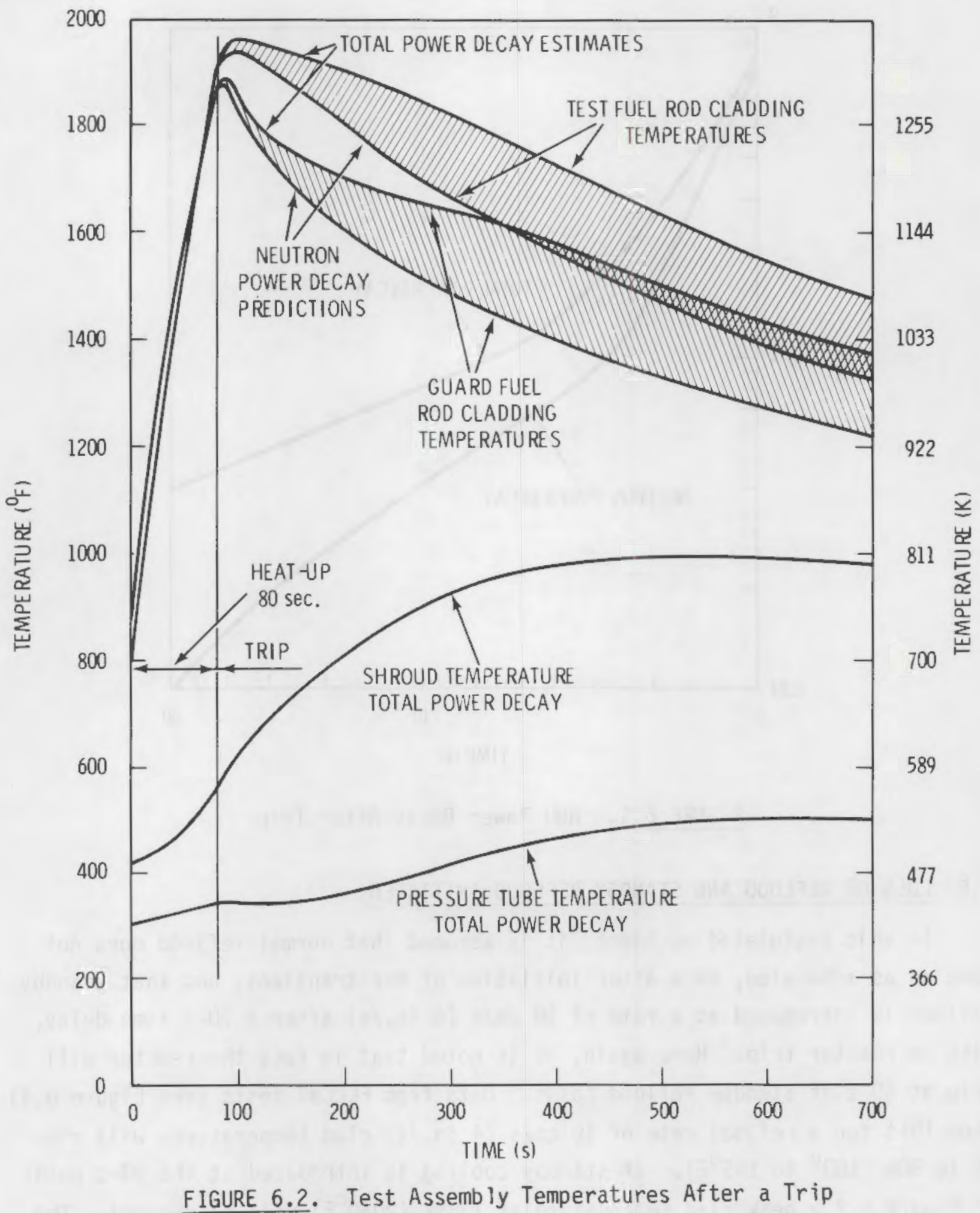




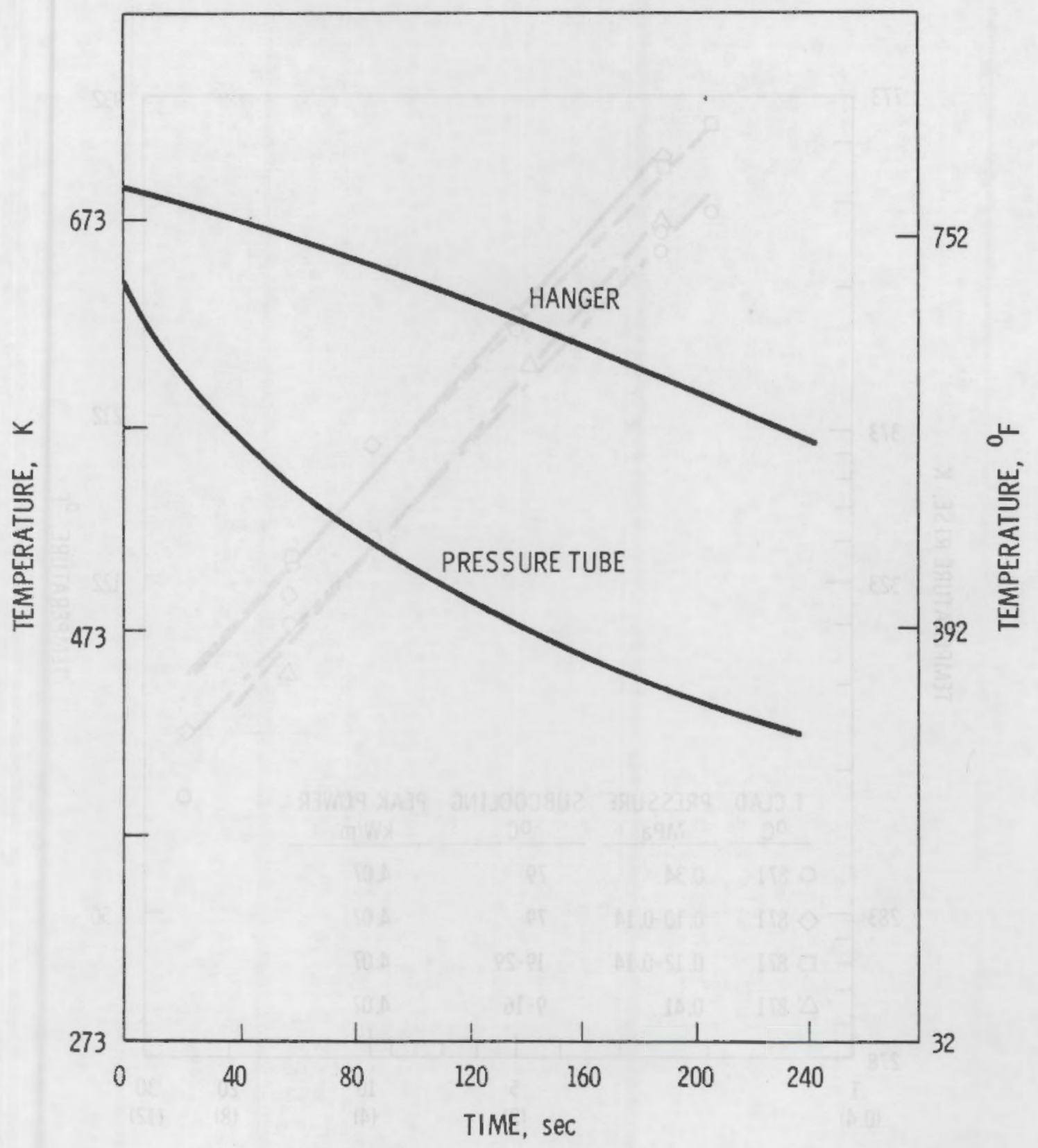

FIGURE 6.3. Temperatures Above Test Assembly After a Trip with No Steam Flow 


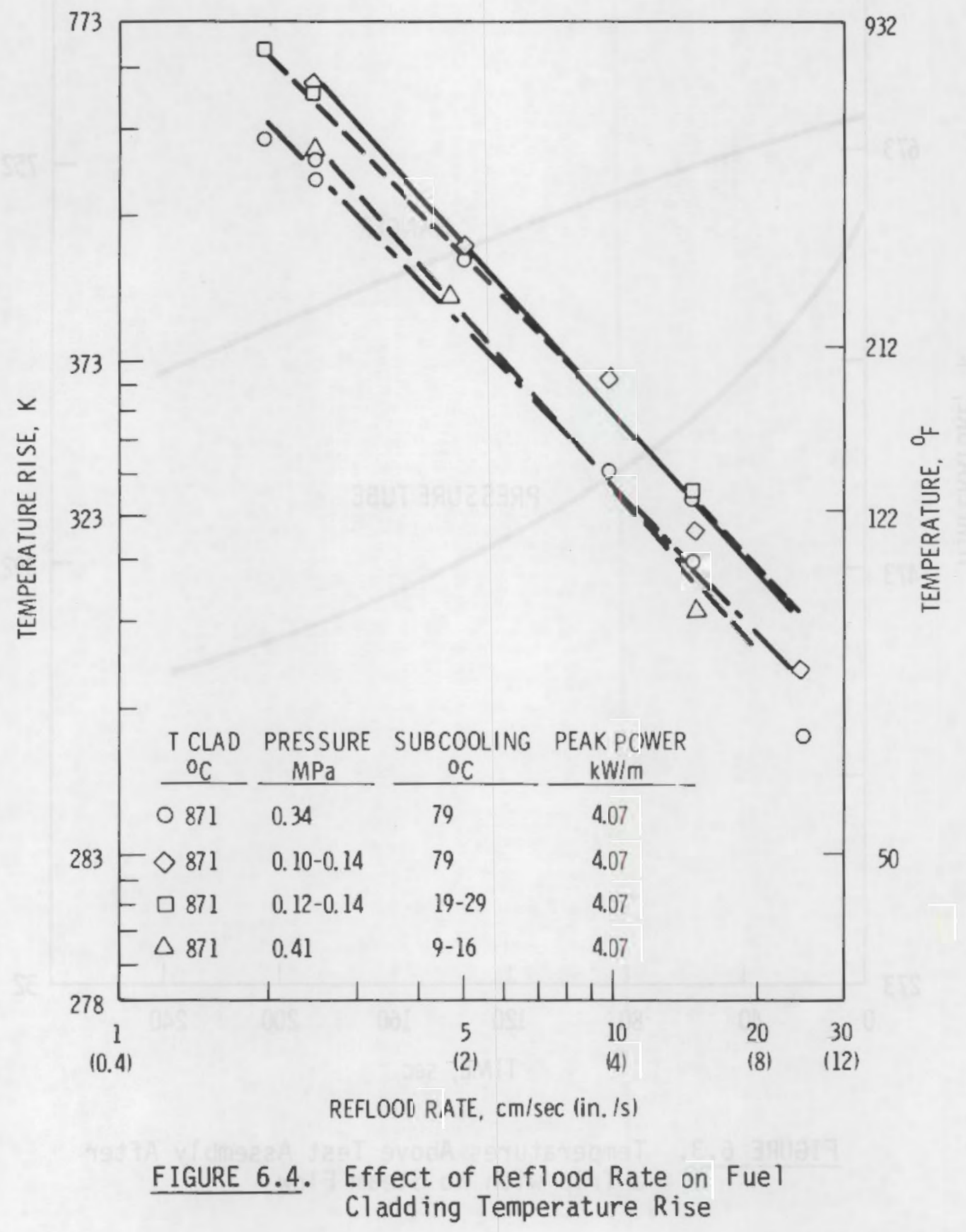

6.8 
exiting from the test assembly has a temperature not much greater than saturation, and therefore it will cool down the pressure tube above the fuel assembly faster than in the no reflood case.

\subsection{PARTIAL LOSS OF REFLOOD COOLANT}

The metal-water reaction $\left(\mathrm{Zr}_{-}-\mathrm{H}_{2} \mathrm{O}\right)$ at the elevated temperatures possible in this test could contribute to test heating. The net contribution would be the difference between the heat addition by the reaction and the heat removal by the water available for the reaction. Normally this value is negative. The basic concern is that under accident conditions this net contribution might be positive and large enough to cause assembly temperatures to continue to rise after a reactor trip.

FLECHT test data indicate that conditions are most severe at very low reflood rates of about $1.2 \mathrm{~cm} / \mathrm{s}(0.5 \mathrm{in.} / \mathrm{s})$. For this postulated accident it is assumed that the reflood is initiated after the transient but the reflood rate is one half the programmed rate at a level just above the standby reflood low flow trip setpoint. The NRU reactor is assumed to trip when the fuel cladding temperature reaches $1477 \mathrm{~K}\left(2200^{\circ} \mathrm{F}\right)$, which corresponds to trip setpoints as found in Appendix $D$.

For the analysis, reported in Mohr et a1. (1981), accident reflood rates of $2.5 \mathrm{~cm} / \mathrm{s}(1 \mathrm{in.} / \mathrm{s}$ ) and $1.2 \mathrm{~cm} / \mathrm{s}(0.5 \mathrm{in.s})$ were calculated. The GAPCON-3 computer code was used to compute the value of the test assembly power contributed by the energy release from the $\mathrm{Zr}-\mathrm{H}_{2} \mathrm{O}$ reaction. The $1.2 \mathrm{~cm} / \mathrm{s}$ $(0.5 \mathrm{in.} / \mathrm{s})$ reflood rate case was found to be the most severe. Both Baker and Just (1962), and Cathcart (1976) correlations were used for comparison and the results are illustrated in Figure 6.5 .

The results were incorporated into input to the TRUMP computer code to calculate test assembly temperatures during the accident. The results are illustrated in Figure 6.6.

As is indicated, the peak clad temperature rises on ly slightly above $1478 \mathrm{~K}\left(2200^{\circ} \mathrm{F}\right.$ ) (the temperature at which the trip occurs) before turning around. The shroud and pressure tube temperatures continue to increase for a 


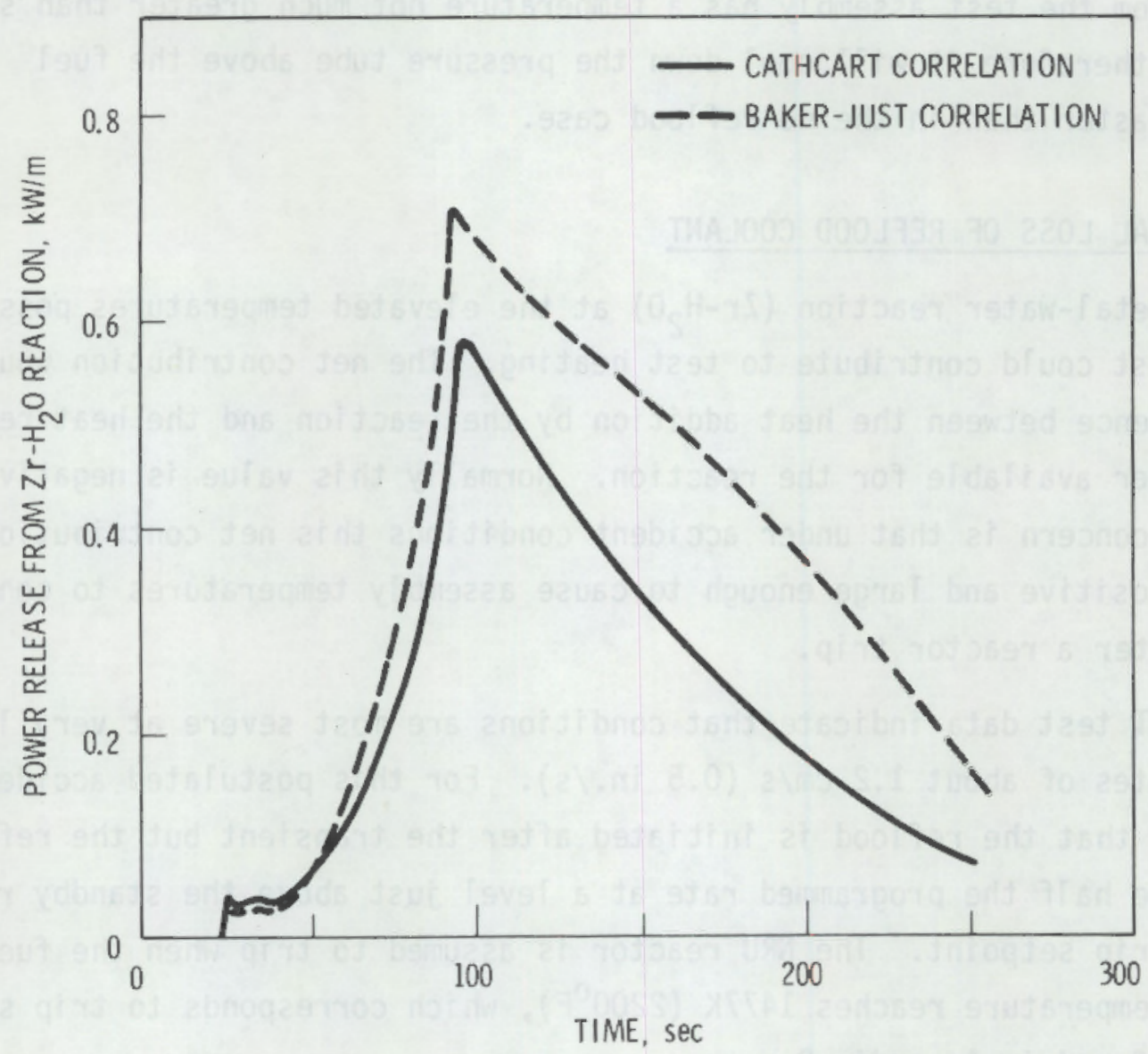

FIGURE 6.5. Contribution of Metal-Water Reaction to Rod Power

short period of time before turning around at a level well below any problem temperatures. Subsequent calculations(a) evaluated fuel cladding temperatures of $1644 \mathrm{~K}\left(2500^{\circ} \mathrm{F}\right)$, which showed that a predictable, stable termination of the accident occurred, based on the high temperature validated correlation (Cathcart 1976).

(a) Letter from R. L. Hjelm to G. M. Hesson, "Effect of Energy Release from $\mathrm{ZrH}_{2} \mathrm{O}$ Reaction on NRU Assembly Temperatures-High Temperature SCRAM Case," March 10, 1980. 


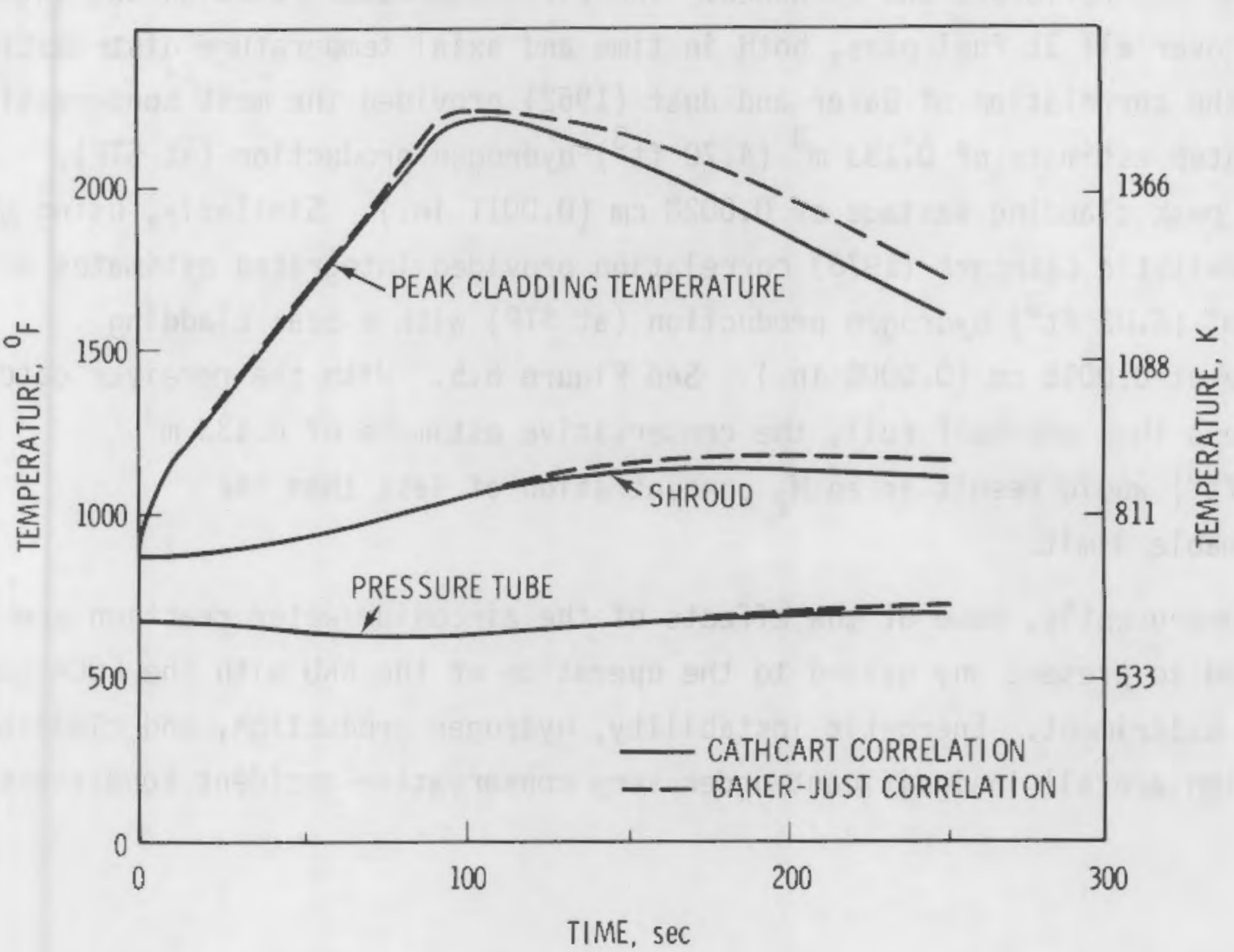

FIGURE 6.6. Shroud, Pressure Tube, and Test Fuel Cladding Temperatures for 21-s Heatup, Slow Reflood and Reactor Trip at $1478 \mathrm{~K}$ (22000F)

A second effect of the zirconium/water reaction has also been evaluated, (a) to determine the maximum cladding oxidation wastage, and to estimate the maximum $\mathrm{H}_{2}$ production that could be anticipated for a postulated test accident in which cladding temperatures of $1478 \mathrm{~K}\left(2200^{\circ} \mathrm{F}\right)$ could be reached. A THERM calculation of an accident terminated at $1444 \mathrm{~K}\left(2140^{\circ} \mathrm{F}\right)$ provided the temperature distribution and time history that conservatively represented such an accident. No reactor trip was assumed, so the time at the peak temperature was extended as the reactor was powered down, and the bundle fuel

(a) Letter from G. M. Hesson to G. E. Russcher, "Total Hydrogen Evolution from NRU Test (Accident)," June 25, 1980. 
cladding was reflooded and quenched. The zirconium/water reaction was integrated over all 31 fuel pins, both in time and axial temperature distribution. Using the correlation of Baker and Just (1962) provided the most conservative integrated estimate of $0.133 \mathrm{~m}^{3}\left(4.70 \mathrm{ft}^{3}\right)$ hydrogen production (at STP), with a peak cladding wastage of $0.0028 \mathrm{~cm}(0.0011 \mathrm{in.})$. Similarly, using the more realistic Cathcart (1976) correlation provided integrated estimates of $0.081 \mathrm{~m}^{3}\left(4.02 \mathrm{ft}^{3}\right)$ hydrogen production (at STP) with a peak cladding wastage of $0.0015 \mathrm{~cm}(0.0006 \mathrm{in.})$. See figure 6.5 . With the receiver catch tank less than one-half full, the conservative estimate of $0.133 \mathrm{~m}^{3}$ $\left(4.70 \mathrm{ft}^{3}\right)$ would result in an $\mathrm{H}_{2}$ concentration of less than the 4\% flammable 1 imit.

Consequently, none of the effects of the zirconium/water reaction are expected to present any hazard to the operation of the NRU with the LOCA simulation experiment. Energetic instability, hydrogen production, and cladding oxidation are all insignificant under very conservative accident conditions. 


\subsection{REFERENCES}

Axford, D. J., I. C. Martin, and S. J. McAuley. 1980. Final Safety and Hazards Analys is for the Battelle LOCA Simulation Tests in the NRU Reactor. AECL 7153, Chalk River Nuclear Laboratory, Chalk River, Ontario, Canada.

Baker, L., and L. C. Just. 1962. Studies of Metal Water Reactions at High Temperatures. III. Experimental and Theoretical Studies of the Zirconium Water Reaction. ANL-6548, Argonne National Laboratory, Chicago, I1 i ino is.

Cadek, F. F., et al. 1972. PWR FLECHT Final Report Supplement. WCAP-7931, Westinghouse Electric Corporation.

Cannon, L. W., and W. E. Meitzler. 1980. LOCA DACS User Manual. 2.0 ed. Pacific Northwest Laboratory, Richland, washington.

Cathcart, J. V. 1976. Quarter lv Progress Report on the Zirconium Metal-Water Oxidation Kinetics Program Sponsored by the NRC Division of Reactor Safety Research for Apri1-June 1976. ORNL/NUREG/TM-41, Oak Ridge Nationa? Laboratory, 0ak Ridge, Tennessee.

Hann, C. R. 1979. Program Plan LOCA Simulations in the National Research University (NRU) Reactor. PNL-3056, Pacific Northwest Laboratory, Richland, Washington.

Hastings, I. J., and M. J. F. Notley. 1979. Prediction of Fission Gas Release from High Burnup Oxide Fue 1. AECL-6682, Atomic Energy of Canada Limited, Chalk River, Ontario, Canada.

Heaberlin, S. W., et al. 1979. Design Basis Neutronics Calculations for NRU LOCA Experiments. PNL-3113, Pacific Northwest Laboratory, Richland, Washington.

Kendrick, S. H. 1979. Control System for the NRC Transient Test. AECL 7152 , Chalk River Nuclear Laboratory, Chalk River, Ontario, Canada.

Lorenz, R. A., D. O. Hobson, and G. W. Parker, 1971. Final Report on the First Fuel Rod Failure Transient Test of a Zircaloy-Clad Fuel Rod Cluster in TREAT. ORNL-4635, Dak Ridge National Laboratory, Oak Ridge, Tennessee.

Mohr, C. L., et al. 1981. Safety Analysis Report: Loss-of-Coolant Accident Simulations in the Nationa 7 Research Universal Reactor. PNL-3093, NUREG/CR-1208, Pac if ic Northwest Laboratory, Richland, Washington for the U.S. Nuclear Regulatory Commission. Available for purchase from the NRC/GPO Sales Program, U.S. Nuclear Regulatory Comission, Washington, DC 20555, and/or the National Technical Information Service, Springfield, VA 22161. 



$$
=
$$


APPENDIX A

\section{INSTALLATION AND CHECKOUT SUMMARY}

To prepare for the experiment, the following activities are planned. Procedures to be followed are referenced, and where data are to be recorded, the procedure or experiment $\log$ to be used is identified. In general, procedures are not provided here, just referenced.

PNL installation and checkout tasks are summarized in the first three sections (A.1 to A.3). These are the Test Train Assemb iy, DACS/Instrumentation Installation and Pretest Checkout, respectively.

CRNL staff is requested to assist (in various capacities) in the installation and checkout of the test train assembly. In addition, CRNL is expected to commission and calibrate the NRU and its loop facilities. These activities are surmarized in Sections A.4 and A.5 of this appendix.

\section{A.1.0 Test Train Assemb iy}

A.1.1 Receiving and Unpacking Tasks. Use procedure QCP-VIII-1.

A.1.1.1 Open shipping container.

A.1.1.2 Remove test train (special strong-back and tooling provided by PNL).

A.1.1.3 Reconstitute to straight configuration.

A.1.1.4 Hydraulically test the test train assembly to verify the lead feed through seal. Use procedure QCP-VIII -3.

A.1.1.4.1 Install test train into the hydraulic test fixture (provided by PNL).

A.1.1.4.2 Conduct feed-through seal test.

A.1.1.4.3 Remove test train from feedthrough seal test fixture. 

A.1.1.5 Remove fue 1 bundle from shroud and remove and account for all interior packing in the fuel bundle. (Special handling tools pro- vided by $\mathrm{PNL}$ ).

A.1.2 Inspection Tasks. Use procedure QCP-VIII-2.

A.1.2.1 Thoroughly inspect bundle for visible indication of shipping damage.

A.1.2.2 Measure and record inter-rod spacing at grid locations to confirm bundle geometry.

A.1.2.3 Disassemble guaró and test fuel rod bund les.

A.1.2.4 Review thermocouple (TC) attachments and locations.

A.1.2.5 Check all wrapped wires, straps, and retainers.

A.1.2.6 Check shroud seals for configuration and fit.

$\mathrm{CP}-1$

A.1.2.7 Confirm readiness to reassemble and close shroud. Sign checkpoint $(\mathrm{CP}-1)$ in the experiment log.

A.1.2.8 Reassemble fuel bund le into shroud and install inlet nozzle (tools by PNL).

A.1.3 Confirm the test train fitup with the pressure tube and top closure regin gauges.

A.l.3.1 Insta11 test train on CRNL strong-back. Move to NRU vertical fixture wall. Use procedure QCP-VIII-4.

A.1.3.2 Insert into pressure tube gauge (provided by CRNL). Use procedure QCP-VIII-4.

A.1.3.3 Measure shroud leak rate.

A.1.3.4 Insert into transfer can. Confirm interface compatibility.

A.1.4 Confirm readiness to insta 11 test train in $\mathrm{U}-2$ loop. 
Sign checkpoint-2 (CP-2) in the experiment $\log$.

A.1.5 Inspect the installation (CRNL A.4.7) of the test train in location L-24. Use procedure QCP-VIII-5. A.1.5.1 Note any handling procedure anomaly. A.1.5.2 Record in-reactor orientation.

A.1.6 Assist installation (CRNL A.4.7) of closure seal for U-2 stump body using CRNL procedure and tools. A.1.6.1 Torque bolts on stump body clamp ring. A.1.6.2 Torque bolts on feed-through clamp ring. A.1.7 Assist leak testing (CRNL A.4.8) closure seal on stump body using CRNL procedure and tools. experiment $\log$.

\section{A.2.0 DACS/Instrumentation}

A.2.1 Certify the initial tapes (20 min each) and discs (10 min each) required for the PTH experiment test series, e.g., 100 tapes and 50 discs.

A.2.1.1 Use procedures from the DACS User Manual, pp. $125-126$.

A.2.2 Initiate DACS operation, using the "Cold Start Procedure" from the DACS User Manual, pp. 103-104. A.2.2.2 Record tape and disc IDs in the experiment $\log$ for the new test series number.

A.2.3 Calibrate the Analog/Digital system using the DACS User Manua 1, pp 116-123. Save calibration printout for the experiment log.

A.2.4 Check TC and SPND channel operability. A.2.4.1 Use procedure QCP-IV-8 to estab 1 ish TC operability.

A.2.4.2 Use procedure QCP-IV-9 to establish SPND operability.

A.2.5 Format the transient graphics display of the DACS, using the DACS User Manual, pp. 89-93. 
A.2.6 Ensure special sensors are defined and working properly. Use the DACS User Manual, pp. 70-72.

A.2.7 Measure conductivity of TCS, SPs and SPNDs.

A.2.7.1 Use procedure QCP-IV-11 to measure TC and SP conductivity.

A.2.7.2 Use procedure QCP-IV-12 to measure SPND conductivity.

A.2.8 Verify location and identity of each TC, SP, and SPND.

A.2.8.1 Use procedure QCP-IV-11 to identify TCS and SPs.

A.2.8.2 Use procedure QCP-IV-12 to identify SPNOs.

A.2.8.3 Confirm readiness to close shroud. Sign

$\mathrm{CP}-1$ checkpoint-1 (CP-1) in the experiment log.

A.2.9 Confirm readiness to insta 11 the test train into the U-2 loop (NRU location L-24).

CP-2 A.2.10 Sign checkpoint-2 (CP-2) in the experiment log.

\section{A.3.0 Pretest Checkout}

A.3.1 Install loop closure head insulation, per drawing H3-41802-Sh1, Sh11 and procedure QCP-VIII-6.

A.3.2 Return shipping container, strong-back and special tooling to PNL.

A.3.3 Install 3 TCs to monitor closure head temperature in accord with PNL drawing H-3-41802-Sh1, and procedure QCP-VIII-8.

A.3.4 Connect instrumentation cables to connectors with grounding wire to closure head in accord with PNL drawing H-3-41802-Sh1 and procedure QCP-VIII-7.

A.3.5 Install 1 TC to monitor instrument cannon connector temperature.

A.3.6 Install cannon connector auxiliary head cooling blower. Use procedure QCP-VIII-8. 
A.3.7 Scan DACS data, print and review it. Produce and retain Alarm, Imediate display, Print data and Special Sensors reports.

A.3.8 Verify trip circuit operation for the following test train sensors: (See Appendix $D$ for operability in each testing period.)

A.3.8.1 Cladding high temperature trip at levels 13 , 15 and 17.

A.3.8.2 Hanger tube high temperature trip.

A.3.8.3 Manual.

A.3.9 Check operability of transient forcing signal (from loop control system to DACS), and inter lock (from DACS to LCS).

CP-4 A.3.10 Signoff $\mathrm{CP}-4$ in experiment log when completed.

A.3.11 Implement trip setpoints (Appendix D, table D-2) for Preconditioning 0peration and record on experiment $\log$.

A.3.12 Record calibration constants, units, and data correlated with REDACE data on experiment log. (See Table C-5 for calibration requirements.)

A.3.13 Circulate U-2 loop water at about $305 \mathrm{~K}\left(90^{\circ} \mathrm{F}\right)$ and $30 \%$ of the full precondition flow rate, $5.6 \mathrm{~kg} / \mathrm{s}$ (90 gpm) scan DACS data, print and review it with the test director.

A.3.14 Heat U-2 loop coolant to about $408 \mathrm{~K}\left(275^{\circ} \mathrm{F}\right)$ 8.62 Mpa (1250 psia), scan DACS data, print and review it with the test director.

A.3.15 Confirm readiness to proceed with Preconditioning Operation.

CP-5 A.3.16 Signoff $\mathrm{CP}-5$ in experiment log.

\section{A.4.0 CRNL Pretest Commissioning}

A.4.1 Observe fuel configuration 
- Verify fuel rod identification (with PNL in A.1.2, see QCP-VIII-2).

A.4.2 Install and check out loop instrumentation thermal and hydraulic controls per CRNL procedures.

A.4.3 Provide core map and neutronics description of repeatable NRU operating conditions for the experiment log.

A.4.4 Provide a pressure tube mockup for a fitup interface gauge with the test train assembly. Assist the gauge check of the test train (see QCP-VIII-4).

A.4.5 Confirm readiness to install the test train in $\mathrm{U}-2$ loop (NRU location L-24).

CP-2 A.4.6 Signoff checkpoint 2 in the experiment $\log$.

A.4.7 Install the test train and the U-2 loop top closure seal (see QCP-VIII-5).

A.4.8 Leak test the loop top ciosure seal per CRNL procedure.

CP-3 A.4.9 Confirm the loop top closure seal acceptance, and signoff checkpoint 3 in the experiment log.

A.4.10 Calibrate loop control, and U-1 loop and U-2 loop instrumentation per CRNL procedures. Use calibration requirements of Table $C-5$.

A.4.11 Provide calibrated signals, ranges to DACS, and units or coefficients for the experiment log.

A.4.12 Fill U-2 loop with water, "static" at equilibrium NRU reactor shutdown temperature.

A.4.13 Establish trip circuit operation for the following sensors or switches (in cooperation with PNL, Task A.3.8). Use Append ix D to determine operability required for each testing period.

- Fuel cladding high temperature at levels 13,15 and 17

- Hanger tube high temperature 
- Outlet piping high temperature

- Manuar

- Reflood low flow rate

- Standby reflood circuit low flow rate

- Pump subcooling temperature

- Surge tank low leve?

- Surge tank high pressure

- Steam low flow rate

- Reflood accumulator low inventory.

- Transient termination time.

A.4.14 Check operability of transient forcing and inter lock signals in cooperation with the DACS (Task A.3.9).

- Signoff checkpoint 4 in the experiment log.

A.4.15 Implement trip setpoints for preconditioning operation

- Use trip setpoints from Appendix D, Table D-2.

A.4.16 Circulate U-2 loop water at about $305 \mathrm{~K}\left(90^{\circ} \mathrm{F}\right)$ and $30 \%$ of the preconditioning flow rate, $5.6 \mathrm{~kg} / \mathrm{s}$ (90 gpm).

A.4.17 Heat U-2 loop water to $408 \mathrm{~K}\left(275^{\circ} \mathrm{F}\right) \pm 10 \%$, $8.62 \pm 0.34 \mathrm{MPa}$ (1250 psia).

A.4.18 Confirm readiness to proceed with preconditioning operation.

CP-5 A.4.19 Signoff checkpoint 5 in the experiment log.

A.5.0 CRNL Support Facilities

A.5.1 Upon receipt of the test train shipment, PNL will request the removal of the test train and special strong-back from the shipping container and its placement on receiving/inspection tables in the reactor hall. 
A.5.2 After completion of instrument lead feed-through seal tests (A.1.3.2), transfer of the test train assembly to the modified CRNL strong-back and relocation to the vertical reactor fixture wall will be requested.

A.5.3 Continued assistance will be requested to separate the test train assembly from the CRNL strong-back and assist $\mathrm{PNL}$ to perform the pressure tube fitup gauge test (A.1.3.5). See QCP-VIII-4.

A.5.3.1 Transfer the test train assembly to the pressure tube fitup gauge and insert it.

A.5.3.2 Transfer the test train assembly to the fuel transfer can and insert it (A.1.3.6).

A.5.3.3 After compatibility is confirmed, transfer it back to the vertical reactor wall strong-back.

CP-2 A.5.4 After checkpoint 2 has been satisfied, install the test train assembly in the U-2 loop, location L-24 of the NRU reactor.

A.5.4.1 Follow applicable CRNL procedures. Reference QCP-VIII-5.

A.5.4.2 Provide for test train assembly installation (QCP-VIII-8) and photography, as requested.

A.5.4.3 Assist installing the test train cables and grounding connection, as requested. Use QCP-VIII-7.

A.5.5 Install insulation and lagging around the L-24 stump body per the figures and procedure summarized in QCP -V I II -6 . 
REFERENCE PROCEDURES

Nealley, C. 1980. NRU Test Train Unpacking, QCP-VIII-1.

Nealley, C. 1980. NRU Test Train Shipping Damage Inspection, QCP-VIII-2.

King, L. L. 1980. NRU Test Train Feed-Thru Leak Check Procedure, QCP-VIII -3.

King, L. L. 1980. NRU Test Train Pressure Tube Gauge Check Procedure, QCP-VIII -4.

King, L. L. 1980. NRU Test Train Insertion into Loop, Overcheck Procedure, QCP-VIII-5.

Hur ley, D. E. 1980. NRU Test Train Insulation Installation Procedure, QCP-VIII -6 .

Marsha11, R. K. 1980. Procedure for Calibration of Self-Powered Neutron Detectors Channels, QCP-IV-B.

Marshal1, R. K. 1980. Procedure for Calibration of Thermocouples Channels, QCP-IV-9.

Marsha11, R. K. 1980. Procedure for Check of Se 1f-Powered Neutron Detectors, QCP-IV-12.

Marshal1, R. K. 1980. Procedure for Check of Test Assembly of Thermocouples, QCP-IV-11.

Marsha11, R. K. 1980. Procedure for Connecting Jumper Cables to Test Train Connectors, QCP-VIII-7.

Marshal1, R. K. 1980. Procedure for Disconnecting Jensen Cables from Test Assembly, QCP-VIII-8.

Marshai1, R. K. 1980. Procedure for Measurement of Self-Powered Neutron Detector Resistances after Test Assembly Insertion in the NRU, QCP-IV-13, Rev. 0 . 

APPENDIX B

EXPERIMENT OPERATIONS SUMMARY 


\section{APPENDIX B}

\section{EXPERIMENT OPERATIONS SUMMARY}

The following activities are planned to occur after the test train assembly has been installed in loop U-2 and position L-24 of the NRU reactor, and has been checked out to establish that all systems are operational and all instrument calibrations are acceptable. The experiment consists of the PNL Preconditioning Activities (B.1.0), and iteratively operating the PNL Pretransient Activities (B.2.0) and PNL Transient Activities (B.3.0) for a series of up to 30 tests. Similar CRNL operations are summarized in Sections B.4.0, B.5.0, and B.6.0. In addition, CRNL Support Facility activities are described in Section B.7.0. The following summarize the activities and tasks that are planned for the experiment operation.

After completing preconditioning operation, the U-2 loop will provide a (nominal $5 \mathrm{hr}$ ) cooldown period. Subsequently, the U-2 loop will be disconnected without special (chill block) cooling provisions for the test train because the estimated decay heat generation in th test train produces a peak cladding temperature of $547 \mathrm{~K}\left(526^{\circ} \mathrm{F}\right)$, we 11 below the allowable temperature of $700 \mathrm{~K}\left(800^{\circ} \mathrm{F}\right)$. Approximately $11 \mathrm{hr}$ will be required to reconnect the $\mathrm{U}-1$ steam supply and reflood piping to provide subsequent cooling to the test train. During that period, no coolant is assumed to be available (only radiation).

\section{B.1.0 Preconditioning Activities \\ B.1.1 With DACS in the steady-state mode, scan the data, print and review it at "zero" reactor power, water flow at about $5.3 \mathrm{~kg} / \mathrm{s}(90 \mathrm{gpm})$ and temperature at about $408 \mathrm{~K}\left(275^{\circ} \mathrm{F}\right)$ and pressure at $8.62 \mathrm{MPa}$ (1250 psia). \\ B.1.2 Initialize all SPND Keithley amplifiers. Use quality control procedure, QCP-IV-8. \\ B.1.3 Scan DACS data, print and review it with the test director.}


B.1.4 With reactor power increased to about $8.04 \mathrm{MW}$, and with a flowrate of $8.1 \mathrm{~kg} / \mathrm{s}$ (160 gpm), and inlet temperature of $517 \mathrm{~K}\left(472^{\circ} \mathrm{F}\right)$ (pressure is same), repeat Task B.1.3.

B.1.5 With reactor power increased to $63.5 \mathrm{MW}$, and with flowrate, temperature and pressure the same, repeat Task B.1.3.

B.1.6 With the NRU reactor at optimum design operating conditions (see Table $\mathrm{C}-1$ ), power at $127 \mathrm{MW}$, and coolant flow at $16.3 \mathrm{~kg} / \mathrm{s}$ ( $320 \mathrm{gpm})$, repeat Task B.1.3 and record the characterization of reactor operating conditions on the experiment log. Scan DACS data, print and review it with the test director for prototypic preconditioning characteristics.

B.1.7 When data are complete, request a conditional trip of the NRU reactor.

B.1.8 Repeat Task B.1.6, and when complete, request trip of the NRU reactor.

B.1.9 Return DACS to steady-state mode for loop conversion. Scan data hourly.

8.1.10 Prepare instrumentation for loop conversion.

B.1.11 Confirm readiness to proceed with loop conversion.

CP-6 B.1.12 Signoff $C P-6$ in experiment log.

B.2.0 PNL Pretransient Activities

B.2.1 Install a new tape and (2) discs after DACS is returned to idle mode.

B.2.2 For each test of the series, record the following data on the test log. (1) all DACS calibration coefficients and units, (2) data correlated with REDACE results and (3) controlled parameter settings versus desired values and acceptable ranges (Appendix C, Table $\mathrm{C}-2$ and $\mathrm{C}-5$ ). 
B.2.3 Adjust SPND amplifiers as needed, using procedure QCP-IV-8.

B.2.4 Input trip setpoints for pretransient operation (Appendix D, Table D-3) and record on the test log.

B.2.5 With DACS in the steady-state mode, scan the data, print and review it with the test director.

B.2.6 Confirm readiness to begin pre-transient operation.

- Check all control parameter and programed settings versus requirements in Appendix $C$, Table C-2 and Appendix D, Table D-3.

$C P-7$

- Signoff CP-7 in experiment log.

B.2.7 With reactor power at nominally $50 \%$ of pretransient power, $4.0 \mathrm{MW}$, a steam flow rate of $0.277 \mathrm{~kg} / \mathrm{s}$ $(2200 \mathrm{lbm} / \mathrm{hr})$ and an outlet pressure of $0.276 \mathrm{MPa}$ (40 psia), scan DACS data, print and review it.

B.2.8 With full steam flow rate of $0.378 \mathrm{~kg} / \mathrm{s}$ (3000 $\mathrm{lbm} / \mathrm{hr}$ ) and reactor power at $8.04 \mathrm{MW}$, and other operating conditions as specified in Appendix C, Table $\mathrm{C}-2$, scan DACS data, print and review it with the test director.

B.2.9 Confirm reactor operating condition acceptability based on the measured fuel cladding temperature, planned test conditions and Appendix $C$, Table $\mathrm{C}-2$ requirements.

B.2.10 Input transient trip setpoints (Appendix D, Table D-4).

B.2.11 Confirm readiness to begin transient operation.

B.2.12 Signoff CP-8 in experiment $\log$.

B.2.13 Switch DACS to transient mode $20 \mathrm{~s}$ before issuing the verbal command "BEGIN THE TRANSIENT," (directed to LCS operator for interlock control). 


\section{B.3.0 PNL Transient Test Activities}

B.3.1 Shutdown the reactor when the test fuel bundle quench is complete. Issue experiment shutdown directive, so that the reactor is shut down and control is returned to DACS (interlock controlled transient forcing signal $=0$ ).

B.3.2 Observe reflood coolant volume necessary to quench the fuel rod selected. Record estimate on the test $\log$.

B.3.3 Return DACS to steady-state (SS) mode, print, and record preliminary results in CS-PTH-1NNO1.

8.3.4 Historically scan selected channels to evaluate peak cladding temperatures and quench times.

B.3.5 Confirm that transient test is complete and that the test train assembly is ready to be drained. Signoff

CP-9 checkpoint-9 in the test log.

B.3.6 Leave DACS in SS mode, print system $\log$ and scan data hourly.

B.3.7 Place DACS in idle mode for calibration using the DACS User Manual, pp. 89-93, recalibrate if necessary and record in the test $\log$.

8.3.8 Terminate the current test on DACS

8.3.8.1 Create three tape copies of data using the DACS User Manual, pp. 84-85, as time permits.

8.3.8.2 Copy DPIF, remove disc pack and recertify if necessary.

B.3.9 Repeat Sections 8.2 and B.3 until a 11 tests of the series (Appendix C, Table $\mathrm{C}-4$ ) have been completed.

\section{B.4.0 CRNL Preconditioning Operations}

B.4.1 Establish "zero" power operation at approximately $1.0 \mathrm{MW}$, inlet pressure at about $8.6 \mathrm{MPa}$ (1250 psia), minimum coolant flow at about $5.3 \mathrm{~kg} / \mathrm{s}(90 \mathrm{gpm})$, 


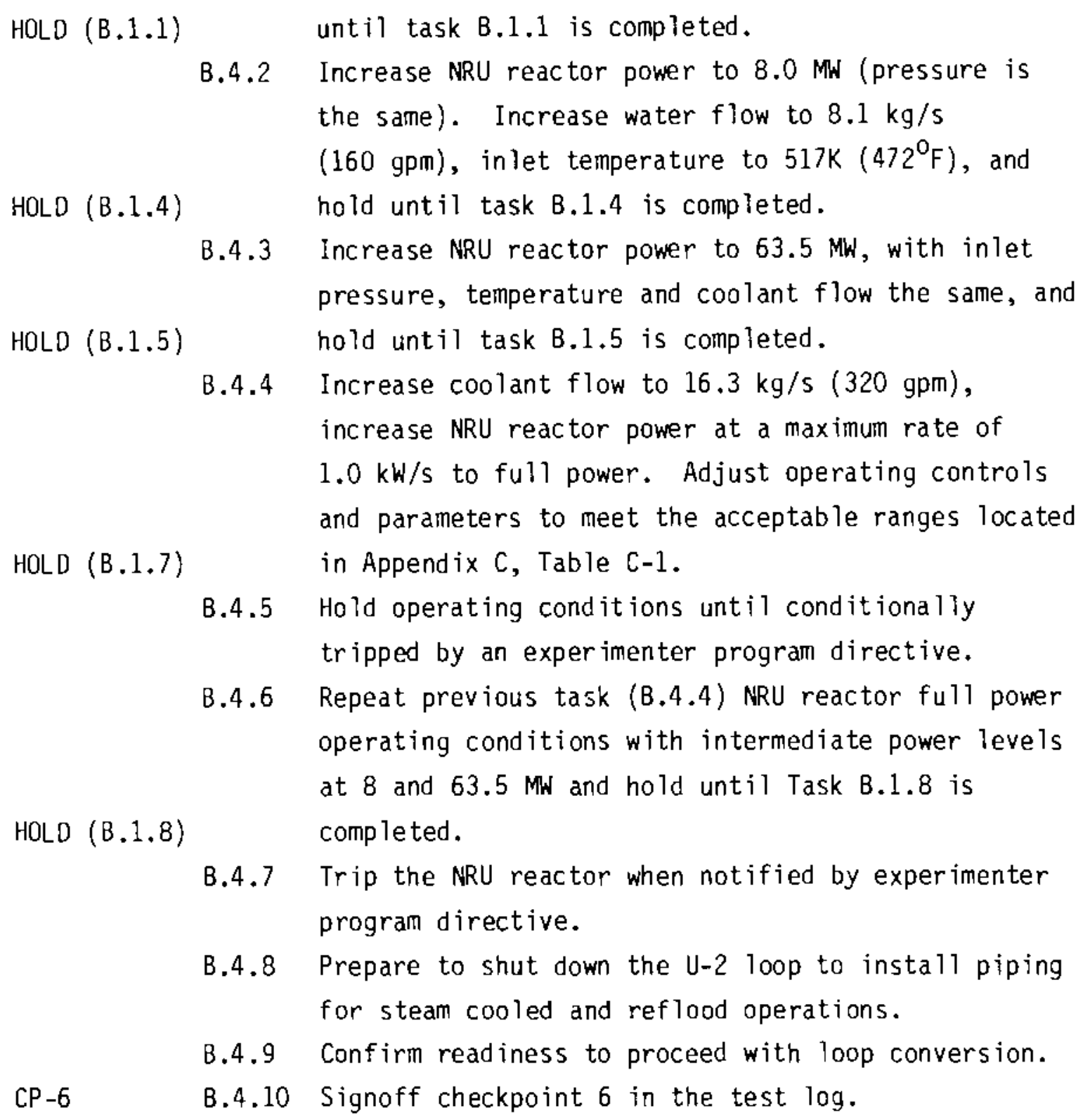

B.4.8 Prepare to shut down the U-2 loop to insta 11 piping for steam cooled and reflood operations.

B.4.9 Confirm readiness to proceed with loop conversion.

CP-6 B.4.10 Signoff checkpoint 6 in the test log.

B.5.0 CRNL Pretransient Operations

B.5.1 Check and calibrate (if necessary) loop control and U-1 loop instrumentation. Report conversion factors and units to DACS operator (for entry in the test log) and to update DACS data. 
B.5.2 Establish and implement loop operating and control conditions; see Appendix C, Table C-2 and Table C-4 for values and acceptable ranges.

B.5.3 Establish and input pretransient trip setpoints; see Append ix 0 , Table $0-3$ for setpoint values. Confirm that two linear rate and at least two log rate neutron flux (ion chambers) detectors are being recorded for the experimenter in the NRU reactor control room.

CP-7 B.5.4 Confirm readiness to begin pretransient operation. Signoff checkpoint 7 in the experiment log.

B.5.5 Increase NRU reactor power to $4.0 \mathrm{MW}$ with an out let pressure of $0.276 \mathrm{MPa}$ (40 psia), and steam flow rate of $0.277 \mathrm{~kg} / \mathrm{s}(2200 \mathrm{lbm} / \mathrm{hr})$. Hold until Task B.2.7

HOLD (B.2.7) is completed.

B.5.6 Increase steam flow rate to $0.378 \mathrm{~kg} / \mathrm{s}$ (3000 1bm/hr), and also increase NRU reactor power to about $8.09 \mathrm{MW}$. Adjust operating controls and parameters to meet the values and acceptable ranges located in Appendix C, Table $\mathrm{C}-2$. Hold until

HOLD (B.2.9) Task B.2.9 is completed.

B.5.7 Confirm NRU reactor and loop operations acceptability based on fuel rod cladding temperatures and Appendix $\mathrm{C}$, Table $\mathrm{C}-2$ requirements.

8.5.8 Implement transient trip setpoints. See Appendix $D$, Table D-4 for trip setpoint values.

B.5.9 Confirm readiness to begin transient operation.

CP-8 8.5.10 Signoff checkpoint 8 in the test log.

B.6.0 CRNL Transient Operations

B.6.1 Shutdown the NRU reactor when notified by experimenter shutdown directive. 
B.6.2 Confirm that the interlock controlled transient forcing signal is reset to 0 .

B.6.3 Monitor and report to the DACS operator the reflood coolant volume used for the test log.

B.6.4 Confirm that the transient test is complete

- Signoff checkpoint 9 in test log

- Begin preparations for next test.

- Adjust the $\log$ rate trip setting (if necessary to accomnodate the neutronic noise generated during reflood operation.

B.6.5 Drain the loop, piping and the test train assembly to prepare for repeat operation of Tasks B.5 through B.6 until all proposed tests (Appendix C, Table C-4) are completed. Do not drain for the last test.

B.6.6 If all tests of the series have been completed, do not drain the loop, but prepare to remove the test train from the loop and transport it to the storage bay.

- Install the instrument connector seal caps and the instrumentation protective sleeve.

- Confirm that fuel is not defective.

\section{B.7.0 CRNL Support Facilities}

B.7.1 Crane and Hoist Operations

After checkpoint 9 has been satisifed, remove the test train assembly from the loop, location L-24 of the NRU reactor.

B.7.1.1 Follow applicable CRNL procedures.

B.7.1.2 Prepare to move the test train to the storage bay.

\section{B.7.2 J Rod Flask Operation}

After checkpoint 9 has been satis ifed, remove the test train assembly from the loop, location $L-24$ of the NRU reactor. 
B.7.2.1 Follow applicable CRNL procedures.

B.7.2.2 Align grappling eye of the test train (if necessary), remove the closure block seal and secure instrument cable ends to the grappling eye bolt.

B.7.2.3 Verify that instrument connector seals in the protective sleeve have been installed (B.6.6).

B.7.2.4 Move the test train assembly into the transfer can and fuel transfer elevator.

B.7.3 Fuel Transfer Elevator Operations

B.7.3.1 Verify that the test train assembly and transfer can are compatibie with the fuel transfer elevator.

B.7.3.2 Transfer the test train assembly from the NRU reactor head to the bay canal for transport to the bay storage area.

B.7.4 Examination Bay Operations

B.7.4.1 Transport the test train assembly from the fuel transfer elevator to the bay storage area while still in the transfer can.

B.7.4.2 Remove the test train assembly from the transfer can.

B.7.4.3 Photograph the exterior of the test train; no disassembly is required.

B.7.4.4 Install the protective boot for the inlet nozzle region.

B.7.4.5 Store the test train assembly in a storage cell for subsequent examination. 
APPENDIX C

OPERATING CONTROL PARAMETERS 
APPENDIX C

OPERATING CONTROL PARAMETERS

REACTOR AND LOOP OPERATING CONDITIONS

The PTH experiment will begin with a preconditioning period, during which the objective will be to provide fuel restructuring, cracking and relocation. Ful1-power NRU reactor operation will be required at this time to provide the maximum available linear power for the test assembly fuel rods. During this period of about $1 \mathrm{hr}$ or less, the U-2 loop will provide water cooling to the test train, and necessary steady-state data will be acquired, recorded (by DACS), and verified. Fission product generation will be minimized. Three surmary sets of preconditioning operation values and limits are provided in Table C-1: 1) low flow rate, 2) low loop pressure, and 3) optimum experiment design conditions. The acceptable ranges are specified to assure that each test planned for this experiment will be able to achieve its objectives and goals, summarized above, in Section 2.0 .

During the pretransient operation period, the NRU reactor will simulate the initial stages of a LOCA in a PWR. The reactor power will simulate the nearly constant decay heating during the loss of steam coolant flow and initiation of reflood water flow. Pretransient steam cooling will be provided by the U-1 loop. However, the transient valve control for both steam and reflood water will be provided by the loop control system. Table $\mathrm{C}$-2 summarizes the control parameters, pretransient operating conditions and ranges designed to achieve the experiment objectives.

The transient phase will require no changes to the loop configuration or NRU reactor operation, but additional contro 1 parameters and transient operation ranges are established for the reflood coolant transients, and are summarized in Table C-3. 
To facilitate cross reference between the above operating conditions, their acceptable ranges and the planned test goal conditions, Table 2.1 is reproduced here as Table $\mathrm{C}-4$ with data acded for reflood quench times and test terminus times.

LOOP CONTROL INSTRUMENT CALIBRATION

Table C-5 lists the loop instrumentation for which documented calibration information is to be provided, together with the operating range over which the calibration is to apply and the desired accuracy of the calibration. Ranges for trip sensor instruments are contained in Appendix D. 
TABLE C-1. Preconditioning Operation Surmary

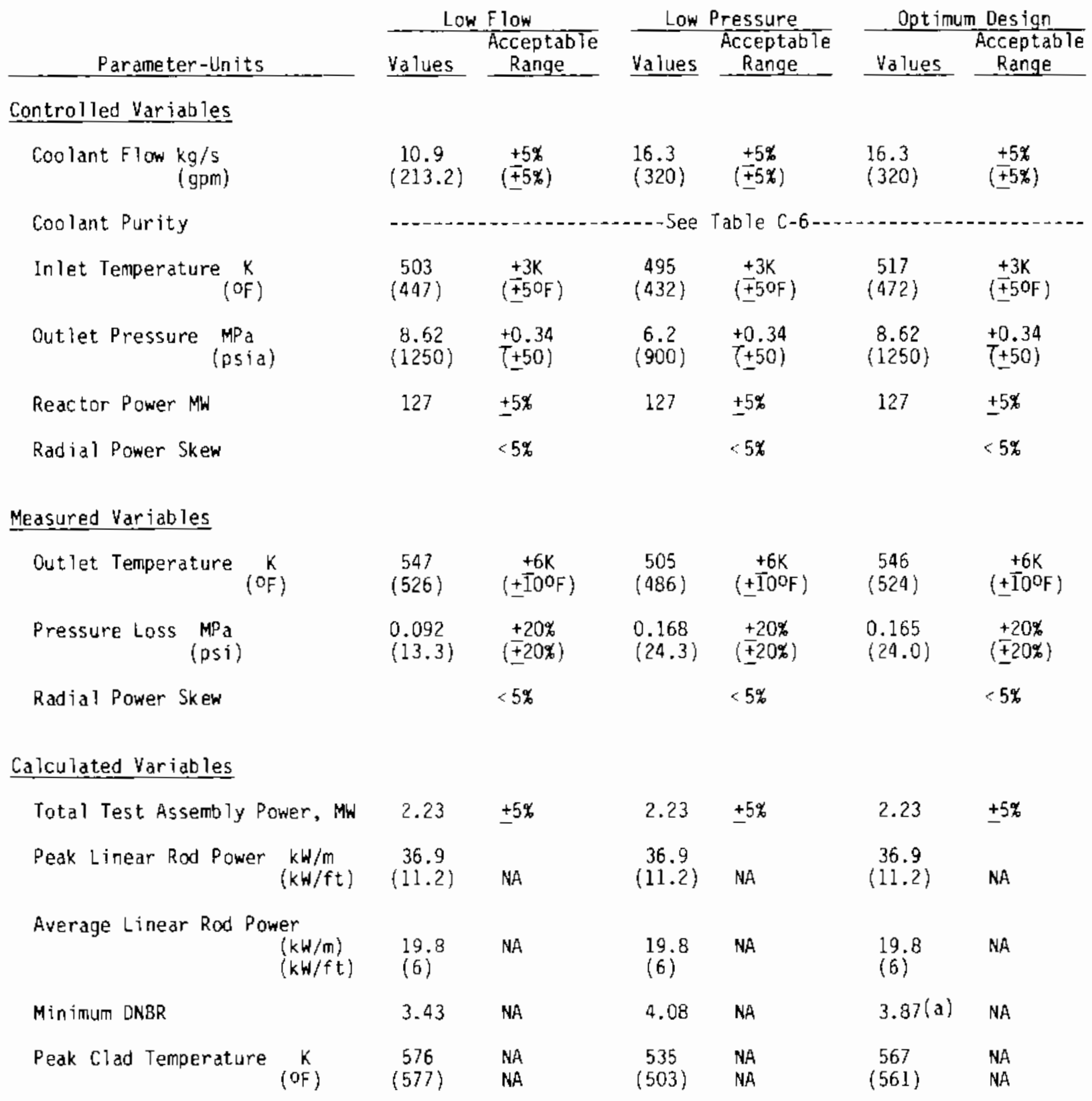

(a) DNBR minima compounded for the optimum design acceptable range of variables is 2.93 , based on a memo from W. A. Prather to G. M. Hesson, July 3l, 1980, NRU-DNBR Sensitivity Analys is. 
TABLE C-2. Pretransient Operating Condition Summary

\begin{tabular}{|c|c|c|c|}
\hline Parameter-Units & \multicolumn{2}{|c|}{ Value } & $\begin{array}{c}\text { Acceptab le } \\
\text { Range } \\
\end{array}$ \\
\hline Avg Coolant Flow, (a) $\mathrm{kg} / \mathrm{s}(1 \mathrm{bm} / \mathrm{hr})$ & 0.378 & $(3000)$ & $\pm 5 \%$ \\
\hline Coolant Inlet Temperature, ${ }^{(a)} \mathrm{K}\left({ }^{\mathrm{O}} \mathrm{F}\right)$ & 436 & $(325)$ & $\pm 3 K\left( \pm 5^{\circ} \mathrm{F}\right)$ \\
\hline Coolant Purity & $\cdots$ & See Table & $C-6-\ldots-\cdots$ \\
\hline Total Test Assembly Power, $\mathrm{kW}(\mathrm{kw})$ & 141 & $(141)$ & $+5 \%$ \\
\hline Out let Pressure, ${ }^{(a)} \mathrm{MPa}$ (psia) & 0.276 & $(40.0)$ & $\pm 5 \%$ \\
\hline Max Test Rod Power, $\mathrm{kW} / \mathrm{m}(\mathrm{kW} / \mathrm{ft})$ & 1.80 & $(0.550)$ & NA \\
\hline Max Guard Rod Power, kW/m $(\mathrm{kW} / \mathrm{ft})$ & 2.13 & $(0.648)$ & NA \\
\hline Average Test Rod Power, $\mathrm{kW} / \mathrm{m}(\mathrm{kW} / \mathrm{ft})$ & 1.25 & $(0.384)$ & NA \\
\hline Max $\mathrm{Cl}$ adding Surface Temperature, $\mathrm{K}\left({ }^{\circ} \mathrm{F}\right)$ & 700 & $(800)$ & NA \\
\hline
\end{tabular}

(a) Measured values, others are derived values

TABLE C-3. Transient 0perating Condition Sumary

\begin{tabular}{|c|c|c|c|}
\hline Parameter-Units & \multicolumn{2}{|c|}{ Value } & $\begin{array}{c}\text { Acceptable } \\
\text { Range }\end{array}$ \\
\hline Reflood Rate, $(\mathrm{a}) \mathrm{m} / \mathrm{s}(\mathrm{in.} / \mathrm{s})$ & $0.013-0.254$ & $(0.5-10)$ & $\pm 5 \%$ \\
\hline Reflood Temperature, ${ }^{(a)} \mathrm{K}\left({ }^{\mathrm{O}} \mathrm{F}\right)$ & 326 & $(127)$ & $\pm 6 K\left( \pm 10^{\circ} \mathrm{F}\right)$ \\
\hline Reflood Delay Times, ${ }^{(a)}$ s & $3-77$ & $(3-77)$ & $\pm 0.1 \mathrm{~s}$ \\
\hline Reflood Water Purity & $-\ldots+\ldots-n$ & ee Table & $-\cdots$ \\
\hline Max Test Rod Power, $\mathrm{kW} / \mathrm{m}(\mathrm{kW} / \mathrm{ft})$ & 1.80 & $(0.550)$ & NA \\
\hline Max Guard Rod Power, kW/m ( $\mathrm{kW} / \mathrm{ft})$ & 2.13 & $(0.648)$ & NA \\
\hline
\end{tabular}

(a) Measured values, others are derived values 
TABLE C-4. Prototypic(a) Therma 1-Hydraulic Test Series Plan

\begin{tabular}{|c|c|c|c|c|c|c|c|c|c|}
\hline \multirow{3}{*}{$\begin{array}{l}\text { Test } \\
\text { Day }\end{array}$} & \multirow{3}{*}{$\begin{array}{l}\text { Series } \\
\text { Number }\end{array}$} & \multirow{3}{*}{$\frac{\text { Ref lood }}{\mathrm{m} / \mathrm{s}}$} & \multirow{3}{*}{$\frac{\text { Rate }}{\text { in./s }}$} & \multirow{3}{*}{$\begin{array}{l}\text { Reflood } \\
\text { Delay } \\
\text { Time, s }\end{array}$} & \multicolumn{2}{|c|}{$\begin{array}{c}\text { Reflood } \\
\text { Quench Times }\end{array}$} & \multicolumn{2}{|c|}{ Predicted (b) } & \multirow[b]{2}{*}{$\begin{array}{l}\text { Terminus } \\
\text { Time }\end{array}$} \\
\hline & & & & & $\begin{array}{l}\text { Peak } \\
\text { Temp., }\end{array}$ & Bundle, & \multicolumn{2}{|c|}{$\begin{array}{c}\text { Peak Cladding } \\
\text { Temperature }\end{array}$} & \\
\hline & & & & & & 5 & $\mathrm{~K}$ & $\mathrm{~F}$ & 5 \\
\hline 2 & 101 & 0.102 & 4.0 & & 80 & 120 & $<811$ & $<1000$ & 540 \\
\hline 2 & 102 & 0.102 & 4.0 & 20 & 120 & 160 & 922 & 1200 & 540 \\
\hline 2 & 103 & 0.102 & 4.0 & 29 & 135 & 180 & 977 & 1300 & 540 \\
\hline 2 & 104 & 0.102 & 4.0 & 37 & 150 & 200 & 1033 & 1400 & 540 \\
\hline 3 & 105 & 0.051 & 2.0 & 7 & 255 & 780 & 1033 & 1400 & 1082 \\
\hline 3 & 106 & 0.051 & 2.0 & 19 & 290 & 800 & 1088 & 1500 & 1080 \\
\hline 3 & 107 & 0.051 & 2.0 & 30 & 315 & 810 & 1144 & 1600 & 1080 \\
\hline 3 & 108 & $0.048^{(d)}$ & 1.9 & $3^{(c)}$ & 250 & 900 & 1033 & 1400 & 1140 \\
\hline 3 & 109 & 0.038 & 1.5 & 3 & 365 & 1700 & 1144 & 1600 & $1440^{(i)}$ \\
\hline 3 & $110^{(g)}$ & $0.038^{(g)}$ & $1.5^{(g)}$ & 11 & 410 & 1800 & 1200 & 1700 & $1440^{(i)}$ \\
\hline 3 & 111 & 0.038 & 1.5 & 11 & 410 & 1800 & 1200 & 1700 & $1440^{(i)}$ \\
\hline 3 & 112 & 0.076 & 3.0 & 32 & 185 & 280 & 1033 & 1400 & 720 \\
\hline 4 & 113 & 0.204 & 8.0 & 39 & 115 & 120 & 1033 & 1400 & 270 \\
\hline 4 & $114^{(\mathrm{h})}$ & 0.204 & 8.0 & 46 & 125 & 130 & 1088 & 1500 & 270 \\
\hline 4 & 115 & 0.204 & 8.0 & 53 & 135 & 140 & 1144 & 1600 & 270 \\
\hline 4 & 116 & $0.254^{(d)}$ & 10.0 & 40 & 100 & 110 & 1033 & 1400 & 215 \\
\hline 4 & $117^{(\mathrm{h})}$ & 0.254 & 10.0 & 47 & 115 & 180 & 1088 & 1500 & 215 \\
\hline 4 & 118 & 0.254 & 10.0 & 54 & 120 & 130 & 1144 & 1600 & 215 \\
\hline 4 & $119^{(g)}$ & $0.155^{(g)}$ & $6.1^{(g)}$ & 52 & 150 & 170 & 1144 & 1600 & 355 \\
\hline 4 & 120 & 0.155 & 6.1 & 52 & 150 & 170 & 1144 & 1600 & 355 \\
\hline 4 & 121 & 0.076 & 3.0 & 48 & 220 & 310 & 1144 & 1600 & 720 \\
\hline 5 & $122^{(g)}$ & $0.076^{(g)}$ & $3.0^{(9)}$ & 53 & 230 & 320 & 1200 & 1700 & 720 \\
\hline 5 & 123 & 0.076 & $3.0^{(c)}$ & 53 & 230 & 320 & 1200 & 1700 & 720 \\
\hline 5 & $124^{(f)}$ & 0.102 & 4.0 & 37 & 150 & 200 & 1033 & 1400 & 540 \\
\hline 5 & 125 & 0.102 & 4.0 & 51 & 180 & 240 & 1144 & 1600 & 540 \\
\hline 5 & 126 & 0.102 & 4.0 & 70 & 210 & 270 & 1255 & 1800 & 540 \\
\hline 5 & $127^{(f)}$ & 0.102 & 4.0 & 37 & 150 & 200 & 1033 & 1400 & 540 \\
\hline
\end{tabular}


TABLE C-4. Prototypic(a) Thermal-Hydraulic Test Series Plan (contd)

\begin{tabular}{|c|c|c|c|c|c|c|c|c|c|}
\hline \multirow{3}{*}{$\begin{array}{l}\text { Test } \\
\text { Day }\end{array}$} & \multirow{3}{*}{$\begin{array}{l}\text { Series } \\
\text { Number }\end{array}$} & \multirow{2}{*}{ Reflood } & \multirow[b]{2}{*}{ Rate } & \multirow[b]{2}{*}{$\begin{array}{l}\text { Reflood } \\
\text { Delay }\end{array}$} & \multicolumn{2}{|c|}{$\begin{array}{c}\text { Reflood } \\
\text { Quench Times } \\
\end{array}$} & \multicolumn{2}{|c|}{ Predicted(b) } & \multirow[b]{2}{*}{$\begin{array}{l}\text { Termi nus } \\
\text { Time }\end{array}$} \\
\hline & & & & & $\begin{array}{l}\text { Peak } \\
\text { Temp., }\end{array}$ & Bundle, & \multicolumn{2}{|c|}{$\begin{array}{c}\text { Peak Cladding } \\
\text { Temperature }\end{array}$} & \\
\hline & & $\mathrm{m} / \mathrm{s}$ & $i \pi . / 5$ & Time, $s$ & & $\mathrm{~s}$ & $k$ & $\mathrm{~F}$ & $s$ \\
\hline 5 & 128 & 0.033 & 1.3 & & 450 & $>2000$ & 1255 & 1800 & 1660 \\
\hline 5 & 129 & $0.038^{(d)}$ & $1.5^{(\mathrm{d})}$ & 20 & 440 & 1700 & 1255 & 1800 & $1440^{(\mathrm{e})}$ \\
\hline 5 & $130^{(f)}$ & 0.102 & 4.0 & 37 & 150 & 200 & 1033 & 1400 & 540 \\
\hline 5 & 131 & 0.051 & 2.0 & 50 & 355 & 830 & 1255 & 1800 & 1080 \\
\hline 5 & 132 & $0.204^{(d)}$ & $8.0^{(\mathrm{d})}$ & 71 & 165 & 180 & 1255 & 1800 & 270 \\
\hline 6 & $133^{(f)}$ & 0.102 & 4.0 & 37 & 150 & 200 & 1033 & 1400 & 540 \\
\hline 6 & $134^{(h)}$ & $0.254^{(d)}$ & $10.0^{(d)}$ & 72 & 140 & 160 & 1255 & 1800 & 215 \\
\hline 6 & 135 & $0.028^{(d)}$ & $1.1^{(d)}$ & 3 & 625 & $>2000$ & $1310^{(\mathrm{e})}$ & $1900^{(e)}$ & $1960^{(i)}$ \\
\hline 6 & $136^{(f)}$ & 0.102 & 4.0 & 37 & 145 & 210 & 1033 & 1400 & 540 \\
\hline 6 & 137 & $0.038^{(d)}$ & $1.5^{(d)}$ & 32 & 470 & 1700 & $1310^{(\mathrm{e})}$ & $1900^{(\mathrm{e})}$ & $1400^{(i)}$ \\
\hline 6 & 138 & $0.051^{(d)}$ & $2.0^{(\mathrm{d})}$ & 60 & 365 & 900 & $1310^{(\mathrm{e})}$ & $1900^{(\mathrm{e})}$ & 1080 \\
\hline 6 & $139^{(f)}$ & 0.102 & 4.0 & 37 & 150 & 200 & 1033 & 1400 & 540 \\
\hline 6 & 140 & $0.102^{(d)}$ & $4.0^{(\mathrm{d})}$ & 76 & 210 & 240 & $1310^{(\mathrm{e})}$ & $1900^{(\mathrm{e})}$ & 540 \\
\hline 6 & 141 & $0.204^{(d)}$ & $8.0^{(d)}$ & 77 & 175 & 190 & $1310^{(\mathrm{e})}$ & $1900^{(\mathrm{e})}$ & 270 \\
\hline 6 & $142^{(f)}$ & 0.102 & 4.0 & 37 & 150 & 210 & 1033 & 1400 & 540 \\
\hline 7 & $143^{(g)}$ & $0.038^{(g)}$ & $1.5^{(\mathrm{d})}$ & $53^{(d)}$ & 520 & 1800 & $1310^{(\mathrm{e})}$ & $1900^{(e)}$ & $1440^{(i)}$ \\
\hline 7 & $144^{(g)}$ & $0.038^{(d)}$ & $1.5^{(\mathrm{d})}$ & 53 & 520 & 1800 & $1310^{(e)}$ & $1900^{(e)}$ & $1440^{(i)}$ \\
\hline 7 & $145^{(f)}$ & 0.102 & 4.0 & 37 & 150 & 200 & 1033 & 1400 & 540 \\
\hline
\end{tabular}

(a) Operating conditions are described in Appendix $C$.

(b) Predictions are based on a FLECHT heat transfer coefficient correlation used in the TRUMp heat transfer code. Prediction uncertainty $= \pm 28 \mathrm{~K}\left(50^{\circ} \mathrm{F}\right)$.

(c) Minimum delay time $(<3 \mathrm{~s})$ is necessary for the reflood water to arrive at the bottom of the fuel colum after steam flow is stopped.

(d) Final value will be selected from earlier tests in this experiment.

(e) Cladding temperature may exceed $1255 \mathrm{~K}\left(1800^{\circ} \mathrm{F}\right)$, based on parameters evaluated from earlier test results. For safety purposes $1310 \mathrm{~K}\left(1900^{\circ} \mathrm{F}\right)$ will be used as the maximum.

(f) Replicate of Test Number 104.

(g) FLECHT data comparison. The first test of each FLECHT data pair uses a fast fill rate up to the $0.306 \mathrm{~m}$ (1 ft) level of the fuel column, then the selected reflood rate. The second test uses a constant reflood rate.

(h) GE data comparison.

(i) Test terminated before fuel bundle quench. 
TABLE $C-5$. Loop Instrument Calibration

\begin{tabular}{|c|c|c|}
\hline Loop Parameter-Units & \multirow[t]{2}{*}{$\begin{array}{c}\text { Acceptable } \\
\text { Range }\end{array}$} & \multirow[t]{2}{*}{$\begin{array}{l}\text { Acceptable } \\
\text { Accuracy }\end{array}$} \\
\hline $\mathrm{U}-2$ & & \\
\hline \multicolumn{3}{|l|}{ Inlet Coolant Temperature, } \\
\hline$k$ & $394-533$ & $\pm 1 k$ \\
\hline$\left({ }^{\circ} \mathrm{F}\right)$ & $(250-500)$ & $\left( \pm 2^{\circ} \mathrm{F}\right)$ \\
\hline \multicolumn{3}{|l|}{ Out let Coolant Temperature, } \\
\hline$k$ & $408-589$ & $\pm 1 \mathrm{~K}$ \\
\hline$\left({ }^{\circ} \mathrm{F}\right)$ & $(275-600)$ & $\left( \pm 2^{\circ} \mathrm{F}\right)$ \\
\hline $\begin{array}{l}\text { Loop Coolant Flow Rate, } \\
\mathrm{kg} / \mathrm{s} \\
(\mathrm{gpm})\end{array}$ & $\begin{array}{c}3.9^{(a)}-19.3^{(b)} \\
(90-325)\end{array}$ & $\begin{array}{l} \pm 0.4 \mathrm{~kg} / \mathrm{s} \\
( \pm 5 \mathrm{gpm})\end{array}$ \\
\hline \multicolumn{3}{|l|}{ Out let Pressure, } \\
\hline $\mathrm{MPa}$ & $5.52-8.96$ & $\pm 0.3 \mathrm{MPa}$ \\
\hline$(p s i a)$ & $(800-1300)$ & $( \pm \pm 0$ psia $)$ \\
\hline Test Assembly Pressure, & & \\
\hline$M P a$ & $0.021-0.172$ & $\pm 2 \mathrm{kPa}$ \\
\hline$(p s i)$ & $(3-25)$ & $( \pm 0.3)$ \\
\hline \multicolumn{3}{|l|}{$\underline{U-1}$} \\
\hline \multicolumn{3}{|l|}{ Inlet Coolant Temperature } \\
\hline $\mathrm{k}$ & $394-700$ & $\pm 1 k$ \\
\hline${ }^{\circ} \mathrm{F}$ & $(250-800)$ & $\left( \pm 2^{\circ} \mathrm{F}\right)$ \\
\hline \multicolumn{3}{|l|}{ Out let Coolant Temperature } \\
\hline k & $422-978$ & $\pm 6 k$ \\
\hline${ }^{\circ} \mathrm{F}$ & $(300-1300)$ & $\left( \pm 10^{\circ} \mathrm{F}\right)$ \\
\hline \multicolumn{3}{|l|}{ Loop Coolant Flow } \\
\hline $\mathrm{kg} / \mathrm{s}$ & $0.277-0.378$ & $\pm 14 \mathrm{~g} / \mathrm{s}$ \\
\hline $1 \mathrm{bm} / \mathrm{hr}$ & $(2200-3000)$ & $( \pm 100 \mathrm{lbm} / \mathrm{hr})$ \\
\hline \multicolumn{3}{|l|}{ Out let Pressure } \\
\hline $\mathrm{MPa}$ & $0.069-0.345$ & $\pm 0.017 \mathrm{MPa}$ \\
\hline psia & $(10-50)$ & $( \pm 2.5$ psia $)$ \\
\hline Test Assembly & & \\
\hline $\mathrm{MPa}$ & $0.021-0.689$ & $\pm 14 \mathrm{kPa}$ \\
\hline psi & $(3-50)$ & $( \pm 2$ psi) \\
\hline
\end{tabular}

(a) At a temperature of $589 \mathrm{~K}\left(600^{\circ} \mathrm{F}\right)$.

(b) At a temperature of $394 \mathrm{~K}\left(250^{\circ} \mathrm{F}\right)$.

C.7 
TABLE C-6. Water Chemica? Requirements

\begin{tabular}{|c|c|c|c|}
\hline Requirement & Applicability & Acceptable & Limit \\
\hline Deionized & - Preconditioning & $\leq 1 \times 10^{-6}$ & Mho \\
\hline Supp ly & Water Coolant & & \\
\hline & - Pretrasient Steam & $\leq 1 \times 10^{-6}$ & Mho \\
\hline & Coolant & & \\
\hline & - Transient Reflood & $\leq 1 \times 10^{-6}$ & Mho \\
\hline & Water & & \\
\hline Impurity & - Halides & $\leq 1 \mathrm{ppm}$ & \\
\hline Concentrations & - Oxygen & $\leq 2$ ppm & \\
\hline & - Nitrogen & $\leq 10 \mathrm{ppm}$ & \\
\hline & - A11 Other Elements & $\leq 1 \mathrm{ppm}$ & \\
\hline
\end{tabular}

C. 8 
APPENDIX D

TRIP SETPOINT DESCRIPTION 
APPENDIX D

\section{TRIP SETPOINT DESCRIPTIDN}

\section{RATIONALE FOR SETPOINT SELECTION}

Trip setpoints are chosen for one reason--protection (for personnel, the NRU reactor, and its loop facilities). However, the rationale for choosing the setpoint values are developed from two bases: 1) CRNL experience from previous NRU experiments and loop operations and 2) unique operating conditions planned for the PTH test series which have been conservatively compared with safety analyses of worst case accidents. And those have been shown to present no run-away, uncoolable, or unterminated operating conclusion.

The majority of the trip setpoints used for this experiment are based upon the first rationale (CRNL experience) because most sensors and instrumentation are located in CRNL facilities and are under direct control and the responsibility of NRU reactor operations. However, to ensure that planned experiment operations are consistent with CRNL experience and accepted practice, the expected operating limits and requested trip setpoints are compared below.

The basis for trip setpoints unique to this LOCA simulation experiment is founded on the SAR (Mohr et al. 1981). In the three worst-case accidents analyzed, peak fuel cladding temperatures greater than $1478 \mathrm{~K}\left(2200^{\circ} \mathrm{F}\right)$ were successfully controlled and quenched at $\sim 1561 \mathrm{~K}\left(2350^{\circ} \mathrm{F}\right)$ without reaching fuel melting conditions or unstable cladding reaction energetic conditions. Consequentiy, a conservative fuel cladding peak temperature safety limit of $1478 \mathrm{~K}$ $\left(2200^{\circ} \mathrm{F}\right)$ is chosen as the basis for this experiment. A summary of the safety limit temperature and conservative margins used to establish the highest fuel cladding $T C$ trip setpoint is shown in Table $0-1$. The conservative safety margins are discussed below.

Fuel cladding TC trip sensors were designed to detect the peak cladding temperature. However, to represent the uncertainty in predicting the location 
TABLE D-1. Trip Setpoint Margins for Peak Temperature Fuel Cladding Thermocoup les

Fuel cladding peak temperatures safety limit

$\begin{array}{rrr}\frac{K}{1478} & & \frac{{ }^{0} \mathrm{~F}}{2200} \\ -56 & & -100 \\ -44 & & -80 \\ -17 & & -30 \\ 1361 & & 1990\end{array}$

(a) A preliminary predictive safety margin of $-111 \mathrm{~K}$ (2000F) will be used until justified by test data.

(b) The preliminary trip setpoint temperature is $1305 \mathrm{~K}$ (18900F) for levels 15 and 17 .

of the peak fuel cladding temperature during a LOCA, a safety margin of $56 \mathrm{~K}$ $\left(100^{\circ} \mathrm{F}\right)$ is chosen. ${ }^{(a)}$ This includes the uncertainty of thermal hydraulic predictions of the test operating conditions during the reflooding phase. A margin must also account for the time delay designed into the DACS averaging logic for pseudo-sensor processing of fuel cladding TC trip sensor data. Because TC data at each instrumentation level are averaged over $10 \mathrm{~s}$, the maximum hypothetical heatup rate of a worst-case accident (Figure D-1) is used to estimate an upper bound to the pseudo-sensor temperature lag. Even though the maximum expected heatup rate is $<7.5 \mathrm{~K}\left(13.5^{\circ} \mathrm{F}\right)$, Figure $\mathrm{D}-1$ shows a maximum hypothetical heatup rate of $9 \mathrm{~K} / \mathrm{s}\left(16^{\circ} \mathrm{F} / \mathrm{s}\right)$, so a pseudo-sensor temperature lag margin of $44 \mathrm{~K}\left(80^{\circ} \mathrm{F}\right)$ is used. Final1y, an instrument calibration and error margin of $17 \mathrm{~K}\left(30^{\circ} \mathrm{F}\right)$ is used to represent all the instrumentation from sensor to computer. As shown in Table D-1, the tally of safety margins, uncertainties and error margins results in a maximum fuel cladding $T C$ trip setpoint of $1361 \mathrm{~K}\left(1990^{\circ} \mathrm{F}\right)$.

For al1 transient phase operations, the peak temperature occurs closest to instrumentation level 15 or 17 . This is illustrated in Figure D-2 where the goal peak cladding temperature is $1255 \mathrm{~K}\left(1800^{\circ} \mathrm{F}\right)$ and the trip setpoint

(a) A preliminary predictive safety margin of $-111 \mathrm{~K}\left(200^{\circ} \mathrm{F}\right)$ will be used until justified by test data. 


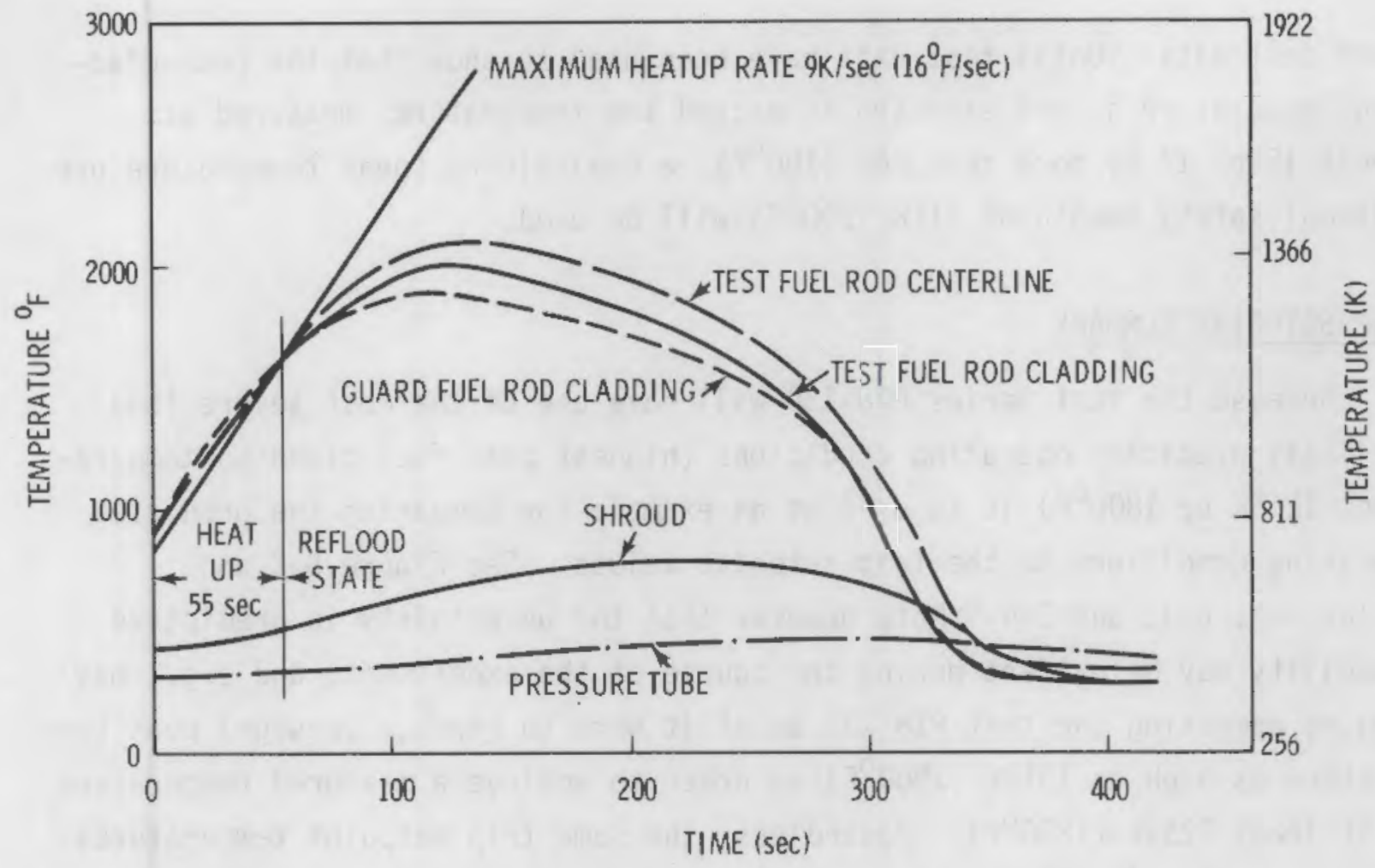

FIGURE D-1. Maximum Hypothetical Heatup Rate and Temperatures for the Test Train Assembly

temperatures for instrument levels 13,15 and 17 are also noted. Because level 13 peak temperatures are predicted to be at least $28 \mathrm{~K}\left(50^{\circ} \mathrm{F}\right)$ below the maximum cladding temperature predicted for most transient test operations, a comparable trip setpoint temperature offset is specified for instrument level 13. For example, the same trip setpoint temperature, (a) $1361 \mathrm{~K}$ $\left(1990^{\circ} \mathrm{F}\right)$, is used for both levels 15 and 17 , near where the peak temperature is expected to occur, while the trip setpoint temperature ${ }^{(b)}$ used for level 13 is $1333 \mathrm{~K}\left(1940^{\circ} \mathrm{F}\right)$.

Analyses were used to predict the location and magnitude of the peak fuel cladding temperature, as well as its axial distribution. The differences between the (calculated) peak cladding temperature and cladding temperatures measured at levels 13,15 , and 17 will be evaluated early in the test series,

(a) The preliminary trip setpoint temperature is $1305 \mathrm{~K}\left(1890^{\circ} \mathrm{F}\right)$ for levels 15 and 17.

(b) The preliminary trip setpoint temperature for level 13 is $1278 \mathrm{~K}$ (18400F). 
using test data. Until test data have been used to show that the peak cladding temperature is not expected to exceed the temperatures measured at levels 15 or 17 by more than $56 \mathrm{~K}\left(100^{\circ} \mathrm{F}\right)$, a preliminary (peak temperature prediction) safety margin of $111 \mathrm{~K}\left(200^{\circ} \mathrm{F}\right)$ will be used.

\section{TRIP SETPOINT SUMMARY}

Because the test series PTH-138 will have one of the most severe (and earliest) predicted operating conditions (highest peak fuel cladding temperature, $1255 \mathrm{~K}$ or $1800^{\circ} \mathrm{F}$ ) it is used as an example for comparing the predicted operating conditions to the trip setpoint values. See Figure D-2 and Tables $0-2, D-3$, and $0-4$. Note however that the uncertainty in predictive capability may be evident during the course of the experiment, and e.g., may require operating the test $\mathrm{PTH}-135$ as if it were to reach a (design) peak temperature as high as $1310 \mathrm{~K}\left(1900^{\circ} \mathrm{F}\right)$ in order to achieve a measured temperature of at least $1255 \mathrm{~K}\left(1800^{\circ} \mathrm{F}\right)$. Regardless, the same trip setpoint temperatures will be used.

The criterion for standard trip setpoint temperatures used at instrumentation levels 13, 15, and 17 requires that at least two TCs must be operating at each leve1. These provide acceptable pseudo-sensor data for the trip circuit. The same standard setpoints would apply if only levels 15 and 17 were operational and level 13 TCs were non-functional (less than 2 TCs operating). See Table D-5 for a summary of the setpoint criteria.

However, if either level 15 or 17 fuel cladding TCs become nonfunctional, an alternate trip setpoint criterion would be used requiring at least two functional TCs on level 13 and at least two functional TCs on level 15 or 17 . These alternate trip setpoints have larger safety margins. Rather than a safety margin of $56 \mathrm{~K}\left(100^{\circ} \mathrm{F}\right)$ to represent the uncertainties of the peak temperature location and LOCA analysis predictions, a safety margin of $83 \mathrm{~K}\left(150^{\circ} \mathrm{F}\right)$ would be used. This would result in fuel cladding TC trip setpoint temperatures for operational instrument levels 13, 15, and 17 of $1305 \mathrm{~K}$ $\left(1890^{\circ} \mathrm{F}\right), 1333 \mathrm{~K}\left(1940^{\circ} \mathrm{F}\right)$ and $1333 \mathrm{~K}\left(1940^{\circ} \mathrm{F}\right)$, respectively. If excessive TC failure should occur, resulting in $\geq 2$ functional TCs on only one level, fallback criteria would be used for level 15 or level 17, based on a combined 


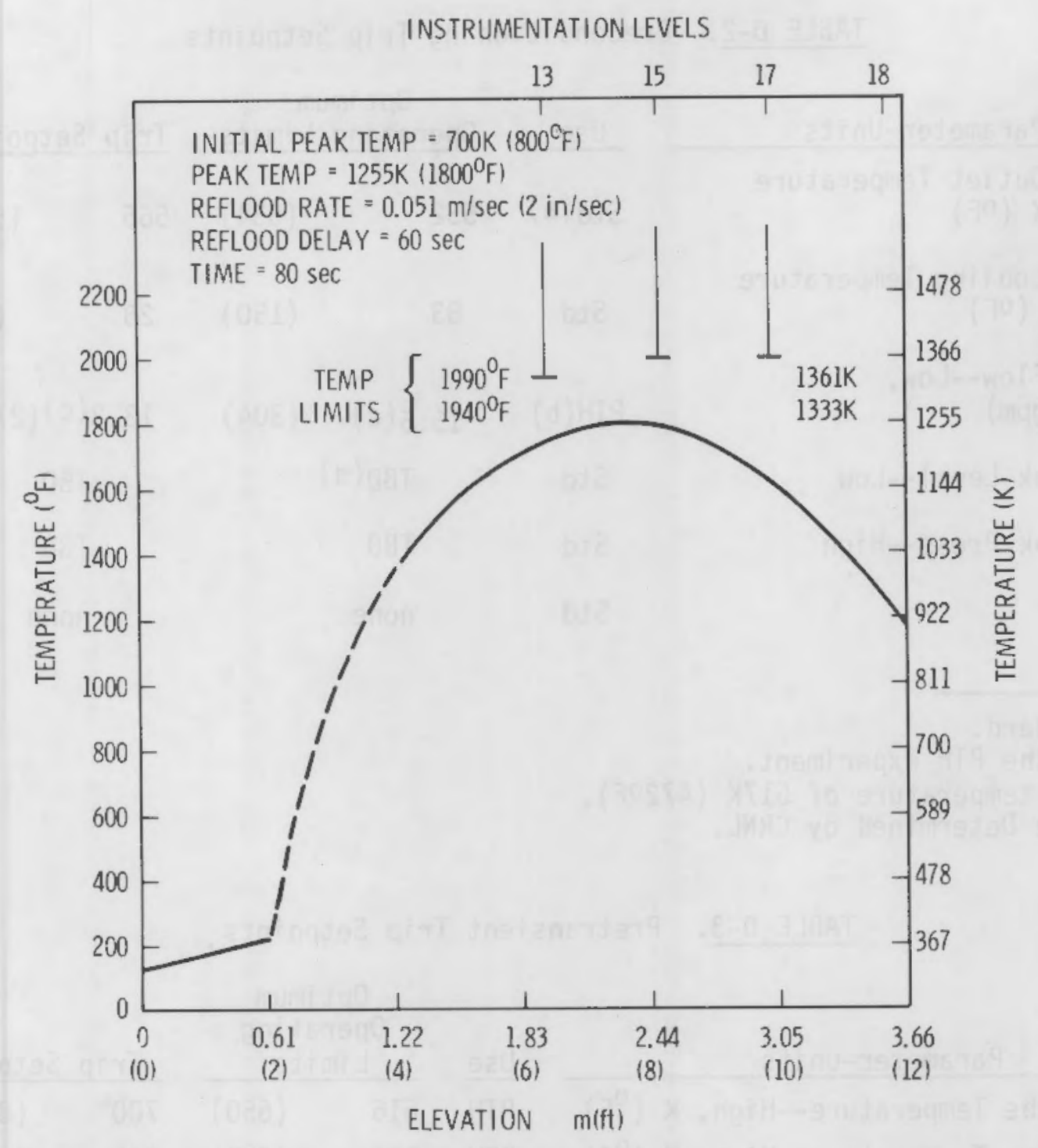

FIGURE D-2. Axial Temperature Profile and Standard Trip Setpoints for Transient Dperation of Test EXP-PTH-138

safety margin of $111 \mathrm{~K}\left(200^{\circ} \mathrm{F}\right)$. However, if only level $13 \mathrm{cladding} \mathrm{TCs}$ are functional, the fall-back criterion would be developed from a review of the data and operating instrumentation. The hanger tube setpoint safety margin would be increased from $56 \mathrm{~K}\left(100^{\circ} \mathrm{F}\right)$ to $111 \mathrm{~K}\left(200^{\circ} \mathrm{F}\right)$. These are criteria summarized in Table D-5.

Operating limits presented in Tables D-2, D-3, and D-4 will be used as the alarm levels for the DACS. 
TABLE D-2. Preconditioning Trip Setpoints

\begin{tabular}{|c|c|c|c|c|c|}
\hline Parameter-Units & Use & \multicolumn{2}{|c|}{ Operating Limits } & \multicolumn{2}{|c|}{ Trip Setpoint } \\
\hline $\begin{array}{l}\text { Coolant Outlet Temperature } \\
\text { High, K (OF) }\end{array}$ & $\operatorname{Std}(a)$ & 552 & $(534)$ & 566 & $(560)$ \\
\hline $\begin{array}{l}\text { Pump Subcooling Temperature } \\
\text { Low, K (OF) }\end{array}$ & Std & 83 & $(150)$ & 28 & (50) \\
\hline $\begin{array}{l}\text { Coolant Flow--Low, } \\
\mathrm{kg} / \mathrm{s}(\mathrm{gpm})\end{array}$ & PTH(b) & $15.5(c)$ & $(304)$ & 13. & (272) \\
\hline Surge Tank Level--Low & Std & TBD $(C$ & & & \\
\hline Surge Tank Press--High & Std & TBD & & & \\
\hline Manual & Std & none & & & \\
\hline
\end{tabular}
(a) Standard.
(b) For the PTH experiment.
(c) At a temperature of $517 \mathrm{~K}$ (4720F).
(d) To Be Determined by CRNL.

TABLE D-3. Pretransient Trip Setpoints

\begin{tabular}{|c|c|c|c|c|c|}
\hline Parameter-Units & \multirow{2}{*}{$\frac{\text { Use }}{\text { PTH }}$} & \multicolumn{2}{|c|}{$\begin{array}{c}\text { Optimum } \\
\text { Operating } \\
\text { Limits }\end{array}$} & \multicolumn{2}{|c|}{ Trip Setpoint } \\
\hline Hanger Tube Temperature--High, $\mathrm{K}\left({ }^{0} \mathrm{~F}\right)$ & & 616 & $(650)$ & 700 & $(\mathrm{~B} 00)$ \\
\hline Outlet Pipe Temperature--High, $\mathrm{K}\left({ }^{\mathrm{O}} \mathrm{F}\right)$ & PTH & 589 & $(600)$ & 700 & (800) \\
\hline Steam flow--Low, $\mathrm{kg} / \mathrm{s}(7 \mathrm{bm} / \mathrm{hr})$ & PTH & 0.378 & $(3000)$ & $75 \%$ & $(75 \%)$ \\
\hline Manual & Std & & & & hone \\
\hline
\end{tabular}


TABLE D-4. Transient Trip Setpoints (example for EXP-PTH-138)

\begin{tabular}{|c|c|c|c|c|c|}
\hline Parameter-Units & \multirow{2}{*}{$\frac{\underline{\text { Use }}}{\text { PTH }}$} & \multicolumn{2}{|c|}{$\begin{array}{l}\text { Optimum } \\
\text { Operating } \\
\text { Limits }\end{array}$} & \multicolumn{2}{|c|}{ Trip Setpoint } \\
\hline $\begin{array}{l}\text { Hanger Tube Temperature--High, } \\
\mathrm{K}(\mathrm{OF})\end{array}$ & & 691 & (785) & 839 & (1050) \\
\hline $\begin{array}{l}\text { Outlet Pipe Temperature--High, } \\
\text { K (OF) }\end{array}$ & PTH & 672 & $(750)$ & 700 & $(800)$ \\
\hline $\begin{array}{l}\text { Fuel Cladding Temperature, (a) K (OF) } \\
\text { 17-High } \\
\text { 15-High } \\
\text { 13-High }\end{array}$ & $\begin{array}{l}\text { PTH } \\
\text { PTH } \\
\text { PTH }\end{array}$ & $\begin{array}{l}1305 \\
1305 \\
1278\end{array}$ & $\begin{array}{l}(1890) \\
(1890) \\
(1840)\end{array}$ & $\begin{array}{l}1361 \text { (b) } \\
1361 \text { (b) } \\
1333(\mathrm{~b})\end{array}$ & $\begin{array}{l}(1990)(b) \\
(1990)(b) \\
(1940)(b)\end{array}$ \\
\hline Standby Reflood Flow--Low, & PTH & & 90 & & \\
\hline $\begin{array}{l}\text { Accumulator Inventory--Low, \% } \\
\mathrm{kg}(1 \mathrm{~b})\end{array}$ & PTH & 22.7 & (50) & 11.3 & (25) \\
\hline Manual & Std & & one & none & \\
\hline
\end{tabular}

(a) Standard trip setpoint criterion, see Table D-5 for non-functional TC criteria.

(b) Preliminary trip setpoints will be lower by 56K (1000F). 
TABLE D-5. Trip Setpoint Criteria for Operating and Non-Functional Fuel Cladding Thermocouples

\begin{tabular}{|c|c|c|c|c|c|c|c|c|}
\hline \multirow{2}{*}{\multicolumn{2}{|c|}{$\begin{array}{l}\text { Summary } \\
\text { Dperating Conditions }\end{array}$}} & Criteria and & \multicolumn{6}{|c|}{ Trip Setpoint Temperature } \\
\hline & & Safety Margins (S.M.) & $\mathrm{K}$ & (OF) & $\mathrm{K}$ & (OF) & K & (OF) \\
\hline 2 & $\begin{array}{l}\leq \text { Operating TCS on each } \\
\text { of levels 13, 15, and } 17\end{array}$ & $\begin{aligned} & \text { Standard } \\
\text { S.M. }= & 56 \mathrm{~K}(1000 \mathrm{~F})\end{aligned}$ & 1333 & (1940) & 1361 & (1990) & 1361 & (1990) \\
\hline 2 & $\begin{array}{l}\text { SOperating TCs on each } \\
\text { of levels } 15 \text { and } 17\end{array}$ & $\begin{array}{c}\text { Standard } \\
\text { S.M. }=56 \mathrm{~K}(1000 \mathrm{~F})\end{array}$ & 1333 & $(1940)$ & 1361 & (1990) & 1361 & (1990) \\
\hline 2 & $\begin{array}{l}\text { SOperating TCS on each } \\
\text { of levels } 13 \text { and } 15,\end{array}$ & $\begin{array}{c}\text { Alternate } \\
\text { S.M. }=84 \mathrm{~K}(150 \mathrm{~F})\end{array}$ & 1305 & $(1890)$ & 1333 & $(1940)$ & 1333 & $(1940)$ \\
\hline & or levels 13 and 17 & & & & & & & \\
\hline 2 & $\begin{array}{l}\leq \text { Operating TCs on on ly } \\
\text { level } 15 \text { or } 17\end{array}$ & $\begin{aligned} & \text { Fall-Back } \\
\text { S.M. }= & 111 \mathrm{~K}(2000 \mathrm{~F})\end{aligned}$ & Non- & nctional & 1305 & $(1890)$ & 1305 & $(1890)$ \\
\hline 2 & $\begin{array}{l}\text { S0perating TCs on on ly } \\
\text { level } 13 \text {, augmented by } \\
\text { other instruments } \\
\text { selected from a review } \\
\text { of data and instru- } \\
\text { ments operational } \\
\text { status }\end{array}$ & $\begin{array}{l}\quad \text { Last Resort } \\
\text { S.M. = } 139 \mathrm{~K}(2500 \mathrm{~F}) \\
\text { ( for cladding TCs). } \\
\text { To be reviewed }\end{array}$ & & To be re & iewed & & & \\
\hline
\end{tabular}


APPENDIX E

FUEL ROD IDENTIF ICATION AND DATA 
APPENDIX E

FUEL ROD IDENTIF ICATION AND DATA

\begin{tabular}{|c|c|c|c|c|c|}
\hline $\begin{array}{l}\text { Fue } 1 \text { Rod } \\
\text { Number }\end{array}$ & $\begin{array}{l}\text { Serial } \\
\text { Number } \\
\end{array}$ & $\begin{array}{l}\text { Fue } 1 \\
\text { Column } \\
\text { Wt }(g) \\
\end{array}$ & & $\begin{array}{c}\text { Fissile } \\
\text { Assay } \\
\end{array}$ & Instrumentation Notes \\
\hline $\begin{array}{l}2 A \\
3 A \\
4 A \\
5 A\end{array}$ & $\begin{array}{l}2 \mathrm{~A} 1 \\
3 \mathrm{Al} \\
4 \mathrm{~A} 1 \\
5 \mathrm{~A} 1\end{array}$ & $\begin{array}{l}2015.1 \\
1946.2 \\
2014.0 \\
2012.5\end{array}$ & $\begin{array}{l}2.90 \\
2.90 \\
2.90 \\
2.90\end{array}$ & $\begin{array}{ll}+0.05 \% & 235 U / U \\
+0.05 \% & 235 U / U \\
\pm 0.05 \% & 235 U / U \\
\pm 0.05 \% & 235 U / U\end{array}$ & $T C-13-3 A-1 R-4 ; T C-13-3 A-1 R-2$ \\
\hline $\begin{array}{l}1 B \\
2 B\end{array}$ & $\begin{array}{l}1 \mathrm{~B} 1 \\
2 \mathrm{~B} 1\end{array}$ & $\begin{array}{l}2013.0 \\
1912.2\end{array}$ & $\begin{array}{l}2.90 \\
2.90\end{array}$ & $\begin{array}{ll}+0.05 \% & 235 \mathrm{U} / \mathrm{U} \\
\pm 0.05 \% & 235 \mathrm{U} / \mathrm{U}\end{array}$ & \multirow{4}{*}{$\begin{array}{l}\text { TC-17-2B-1R-2; TC-17-2B-1R-4; } \\
\text { TC-17-2B-1R-C; } \\
\text { TC-15-3B-1R-4; TC-13-3B-1R-2 } \\
\text { TC-17-5B-1R-3; TC-17-5B-1R-1; } \\
\text { TC-17-5B-1R-C }\end{array}$} \\
\hline $\begin{array}{l}3 B \\
4 B\end{array}$ & $\begin{array}{l}3 B 1 \\
4 B 1\end{array}$ & $\begin{array}{l}1945.1 \\
2014.1\end{array}$ & $\begin{array}{l}2.90 \\
2.90\end{array}$ & $\begin{array}{l}+0.05 \% 235 U / U \\
+0.05 \% \\
0\end{array}$ & \\
\hline $5 B$ & $5 B 1$ & 1912.3 & 2.90 & $\pm 0.05 \% 235 \mathrm{U} / \mathrm{U}$ & \\
\hline $6 \mathrm{~B}$ & $6 \mathrm{~B} 1$ & 2012.9 & 2.90 & $\pm 0.05 \% 235 \mathrm{U} / \mathrm{U}$ & \\
\hline $\begin{array}{l}1 C \\
2 C \\
3 C\end{array}$ & $\begin{array}{l}1 \mathrm{C} 1 \\
2 \mathrm{C} 1 \\
3 \mathrm{C}\end{array}$ & $\begin{array}{l}2017.9 \\
1988.3\end{array}$ & $\begin{array}{l}2.90 \\
2.90\end{array}$ & $\begin{array}{ll}+0.05 \% & 235 U / U \\
\pm 0.05 \% & 235 U / U\end{array}$ & \multirow{4}{*}{$\begin{array}{l}\text { TC-18-3C-1R-1; TC-17-3C-1R-1; } \\
\text { TC-17-3C-1R-C; TC-17-3C-1R-2; } \\
\text { TC-17-3C-1R-3;4 } \\
\text { TC-17-4C-1R-1; TC-17-4C-1R-C; } \\
\text { TC-17-4C-1R-3 } \\
\text { TC-18-5C-1R-4 } \\
\text { TC-13-6C-1R-2; TC-15-6C-1R-4 }\end{array}$} \\
\hline & & & & $\pm 0.05 \% 235 \mathrm{U} / \mathrm{U}$ & \\
\hline $4 C$ & $4 C 1$ & 1912.1 & 2.90 & $\pm 0.05 \% 235 \mathrm{U} / \mathrm{U}$ & \\
\hline $\begin{array}{l}5 C \\
6 C\end{array}$ & $\begin{array}{l}5 \mathrm{Cl} \\
6 \mathrm{Cl}\end{array}$ & $\begin{array}{l}2002.7 \\
1944.0\end{array}$ & $\begin{array}{l}2.90 \\
2.90\end{array}$ & $\begin{array}{ll}+0.05 \% & 235 \mathrm{U} / \mathrm{U} \\
\pm 0.05 \% & 235 \mathrm{U} / \mathrm{U}\end{array}$ & \\
\hline $\begin{array}{l}10 \\
20 \\
20\end{array}$ & $\begin{array}{l}1 D 1 \\
2 D 1\end{array}$ & $\begin{array}{l}1943.4 \\
2004.75\end{array}$ & $\begin{array}{l}2.90 \\
2.90\end{array}$ & $\begin{array}{ll}+0.05 \% & 235 U / U \\
\pm 0.05 \% & 235 U / U\end{array}$ & \multirow{4}{*}{$\begin{array}{l}\text { TC-15-1D-1R-4; TC-15-6C-1R-2 } \\
\text { TC-18-2D-1R-2; } \\
\text { TC-17-3D-1R-4; TC-17-3D-1R-C; } \\
\text { TC-17-3D-1R-3; TC-17-3D-1R-1;2 } \\
\text { TC-15-4D-1R-4; TC-17-4D-1R-4; } \\
\text { TC-18-4D-1R-4; TC-1-4D-1N; } \\
\text { TC-3-4D-1R-4; TC-6-4D-1R-4; } \\
\text { TC-10-4D-1R-4; TC-13-4D-1R-4; } \\
\text { SPND-3-4D-1R-2; SPND-6-4D-1R-2; } \\
\text { SPND-10-4D-1R-2; SPND-13-4D-1R-2; } \\
\text { SPND-15-4D-1R-2; SPND-17-4D-1R-2; } \\
\text { SPND-18-4D-1R-2 } \\
\text { TC-18-5D-1R-4 }\end{array}$} \\
\hline 30 & 3D1 & 1901.0 & 2.90 & $\pm 0.05 \% 235 \mathrm{U} / \mathrm{U}$ & \\
\hline $4 \mathrm{D}$ & 401 & 0.0 & & none & \\
\hline $\begin{array}{l}5 \mathrm{D} \\
6 \mathrm{D}\end{array}$ & $\begin{array}{l}501 \\
601\end{array}$ & $\begin{array}{l}2001.8 \\
2010.0\end{array}$ & $\begin{array}{l}2.90 \\
2.90\end{array}$ & 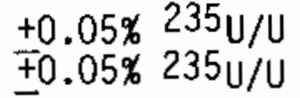 & \\
\hline
\end{tabular}

E.I 
FUEL ROD IDENTIF ICATION AND DATA (contd)

\begin{tabular}{|c|c|c|c|c|}
\hline $\begin{array}{l}\text { Fue } 1 \text { Rod } \\
\text { Number }\end{array}$ & $\begin{array}{l}\text { Serial } \\
\text { Number }\end{array}$ & $\begin{array}{l}\text { Fuel } \\
\text { Column } \\
\text { Wt }(g)\end{array}$ & $\begin{array}{c}\text { Fissile } \\
\text { Assay } \\
\end{array}$ & Instrumentation Notes \\
\hline $\begin{array}{l}1 \mathrm{E} \\
2 \mathrm{E}\end{array}$ & $\begin{array}{l}\text { 1E1 } \\
2 \mathrm{E} 1\end{array}$ & $\begin{array}{l}2016.3 \\
1913.1\end{array}$ & $\begin{array}{lll}2.90+0.05 \% & 235 \mathrm{U} / \mathrm{U} \\
2.90 \pm 0.05 \% & 235 \mathrm{U} / \mathrm{U}\end{array}$ & \multirow{3}{*}{$\begin{array}{l}\text { TC-17-2E-1R-1; TC-17-2E-1R-C; } \\
\text { TC-17-2E-1R-3 } \\
\text { TC-18-2E-1R-1 } \\
\text { TC-18-4E-1R-1 } \\
\text { TC-17-5B-1R-3; TC-17-5B-1R-C; } \\
\text { TC-17-5B-1R-1 }\end{array}$} \\
\hline $\begin{array}{l}3 \mathrm{E} \\
4 \mathrm{E} \\
5 \mathrm{E}\end{array}$ & $\begin{array}{l}3 E 1 \\
4 E 1 \\
\text { 5E1 }\end{array}$ & $\begin{array}{l}2000.7 \\
2003.2 \\
1912.5\end{array}$ & $\begin{array}{lll}2.90+0.05 \% & 235 \mathrm{U} / U \\
2.90 \pm 0.05 \% & 235 \mathrm{U} / \mathrm{U} \\
2.90 \pm 0.05 \% & 235 \mathrm{U} / \mathrm{U}\end{array}$ & \\
\hline $6 \mathrm{E}$ & $6 \mathrm{E} 1$ & 2015.1 & $2.90 \pm 0.05 \% 235 \mathrm{U} / \mathrm{U}$ & \\
\hline $\begin{array}{l}2 \mathrm{~F} \\
3 \mathrm{~F} \\
4 \mathrm{~F} \\
5 \mathrm{~F}\end{array}$ & $\begin{array}{l}2 \mathrm{~F} 1 \\
3 \mathrm{~F} 1 \\
4 \mathrm{~F} 1 \\
5 \mathrm{~F} 1\end{array}$ & $\begin{array}{l}2015.6 \\
2016.3 \\
1946.3 \\
2009.0\end{array}$ & $\begin{array}{ll}2.90+0.05 \% & 235 \mathrm{U} / U \\
2.90+0.05 \% & 235 \mathrm{U} / U \\
2.90+0.05 \% & 235 \mathrm{U} / \mathrm{U} \\
2.90+0.05 \% & 235 \mathrm{U} / \mathrm{U}\end{array}$ & $T C-15-4 F-1 R-2 ; T C-13-4 F-1 R-4$ \\
\hline
\end{tabular}


APPENDIX F

EXPERIMENT PTH

CHECKPOINT RECORD 
APPENDIX F

\section{EXPERIMENT PTH \\ CHECKPOINT RECORD}

PNL

PNL

CRNL

Test Assembly Test Director Test Operator Approved Approval Approval

CP-1 Readiness to close shroud of

CP-1 $\mathrm{CP}-1$ $\mathrm{CP}-1$ the Test Train Assembly

CP-2 Readiness to Install Test
Train Assembly in U-2 Loop

$\mathrm{CP}-2$

$\mathrm{CP}-2$

$\underline{C P}-2$ $(L-24)$

CP-3 Acceptance of Seal on Top CP-3

$\mathrm{CP}-3$

$\mathrm{CP}-3$ Closure Seal Block of U-2 Loop and the Test Train Assemb 1y

CP-4 Acceptance of All Trip Cir-

$\mathrm{CP}-4$ CP-4 CP-4 cuit Operability Required for EXP-PTH-101, - -124

CP-5 Confirm Readiness to Begin Preconditioning Operation of

$\mathrm{CP}-5$

CP-5

$C P-5$ EXP-PTH-101, ---124

CP-6 Confirm Readiness to Begin

CP-6

$\mathrm{CP}-6$

CP-6 $\mathrm{U}-2$ to $\mathrm{U}-1$ Loop Conversion 

APPENDIX G

TEST ASSEMBLY DRAWINGS 
APPENDIX G

TEST ASSEMBLY DRAWINGS

Append ix A of the SAR (Mohr et al. 1981) contains copies of 4 conceptual layout drawings and mechanicai drawings that are representative of the entire drawing package used in the fabrication of the test assembly.

The following list identifies specific assembly drawings.

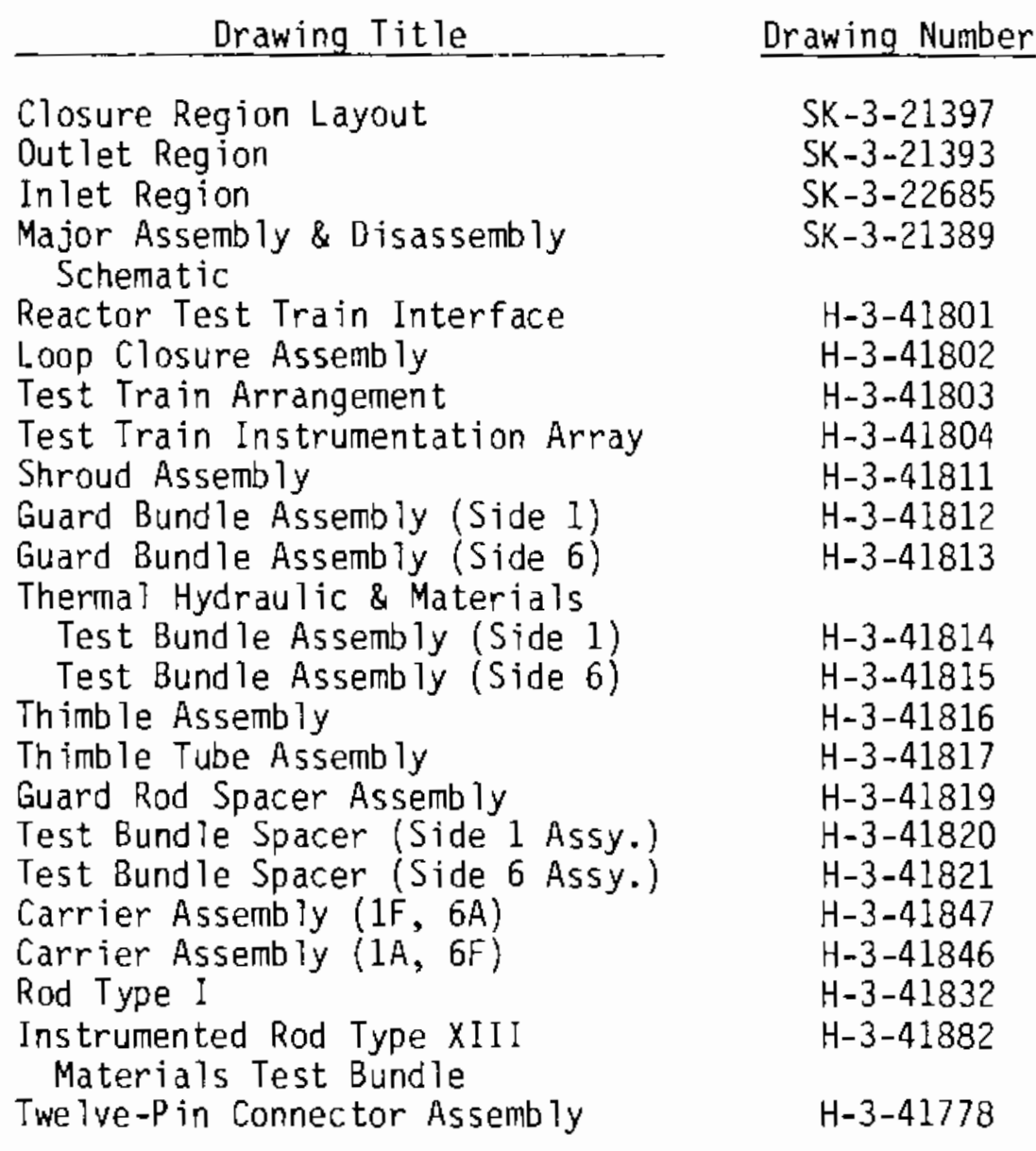



APPENDIX $\mathrm{H}$

DACS SENSOR STATUS REPORT 
ANALJG TETSTIRS

$\mathrm{TC}-3-1 \mathrm{~A}-\mathrm{L}-\mathrm{C}$ $T C-3-4 D-18-4$

$T C-3-5 A-T 1 R-1$

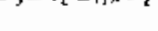

$2 t-76-7 E-46-3$ $16-3-5 i f-1] p-a$

$1,-3-h A-5-C$
$|C-3-1|-2-C$

1) $T C-4-A F-S-C$

i. $T C-4-1 A-C-C$

in $T C-5-1 F-5-C$

37 it $18-6,-4 i s-18-4$

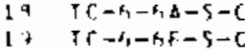

in $\operatorname{Tr}-t,-i f-2-C$

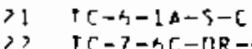

?) $T \Gamma-7-4 \Gamma-\pi q-1$

3 TC $-7-1 P-n R-2$

35 T $[-7-3 A-[T R-3$

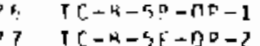

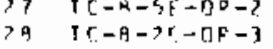

$3 \therefore 1 c-a-7 H-0 R-4$

IC $T C-A-A,-s-C$

i) $1,-9-12-5-C$

i) $T C-3-5 E-T I R-$ ?

35
14
14

31) $12-2,3-2, n-5-c$

$37+[-17-1 ;-5-6$

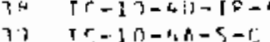

41) $r r-1 n-f_{1} f-5-c$

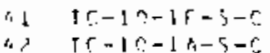

4) $T r-11-t, r-0, r-4$

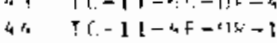

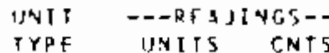

OFE. C $-3301.2-7049$ DFE. F -3301.2-2044 DEC. F -33)1.? $-204 \mathrm{~A}$

BFG. F -33)L.2 -704 AfG. F -7301.2 - 2049 OEF. F - F3ग1.2 -704 DEG. F -3301.2-2048

กEG. F - $1301.2-2049$ OEG. F $2317.72 \quad 2047$ QEE. F -7301.2 -2044 $5301 . ?-2044$
4

DEG. F $\quad 3.71 .72 \quad 3347$ OfG. F - $-3301.2-2048$ DEG. F - $3101.2-2049$ DEG. F $2179.92 \quad 2347$

OEG, F $2379.1 \geq 2047$ DE. F $23917-12 \quad 2047$ DFC. F 2724.72 2047

DFF. F - $\quad-3101 . \geq-3249$ OFS. F - $3321 . ?-204 \mathrm{H}$ $\begin{array}{lll}O E C . F & -3301 . ? & -234 \mathrm{~F} \\ \text { OFG.F } & -3301.2 & -2044\end{array}$

DFG. F -313L.2 -7249 DFE. F - 33OI. -204

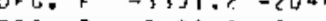
DEG. F -7ग1.? -?04A DEt. F - $-3101.2-2049$ OEG. F $-1311.4-1407$

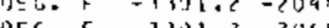

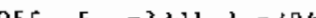
-3)

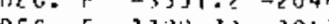

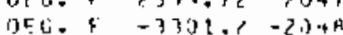

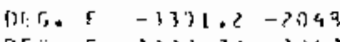

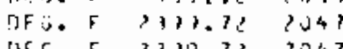

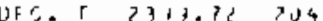
$34 \div 8-31210 .-1149$

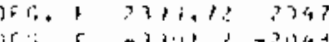
DF 5 . $5-1611 . ?-134$

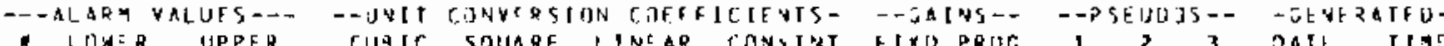
$71.53732000 .57 \quad .004059-.2370546 .8409143 .100$ $71.53732000 .53 .004458-.2370546 .3400143 .100$ $11.557] 2000.54 \quad .00405 \mathrm{H}=.737054 \mathrm{~h} .8400 \quad 143.100$ $11.5373200 n .5 \% .00405 \mathrm{R}-.237054 \mathrm{~h} .8400143 .100$

$71.63732000 .57 \quad 0004059-.2370549 .8400 \quad 143.130$

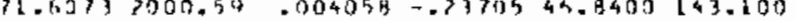
72.3073 2000.37 .004354 -.23105 4h.9410 143.190 $71.63732000 .57 .004059-.237054 h .3400 \quad 143.109$ $71.63732000 .59 .024058+.2370546 .0400193 .100$ $71.43732009 .59 \quad .00405 \mathrm{H}-.2370545 .4400143 .100$

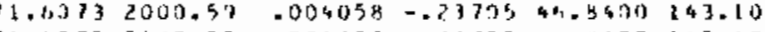
$12.63732007 .53 \quad .004059+.2310545 .8400 \quad 143.109$

$71.50732000 .54 \quad .004059-.7370543 .8400143 .100$ $1.63732000 .59 \quad .004059-.2370546 .9400103 .100$ $71.13132000 .57 \quad 004053 \quad-23765 \quad 46,8400143.100$ $21.03732000 .53 .004155 \%-2370545.7400143 .100$

$71.53732000 .57 \quad .004054-.7370546 .3400143 .130$ $11.53132000 .59 \quad .0041554-.2370545 .8400 \quad 143.100$ 71.50732000 .59 .00445 -.?3705 4h-4400 143.100 $71.30712030 .52 .004054-.7370540 .3400143 .100$

$71.53737000 .54 \quad .004058-.2370544 .4400 \quad 143.100$ $71.573 \quad 2007.59 \quad 004058-.2330544 .4400243 .100$ 71.40732000 .57
71.03732030 .59

$71.63133000 .59 \quad 004057-.23704 \quad 45.4470 \quad 143.100$ 11.ho73 $000.57 .004059-.2370544 .8400 \quad 143.100$

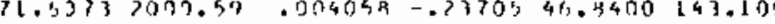

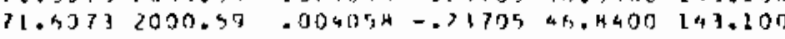

$71.60132000 .57 .004054-.2320544 .4400143 .100$ $71.5273 \quad 2007.57 \quad 0004054-.2370546 .04400143 .100$ $71.59732000 .57 .00455-.7371541 .9400143 .100$

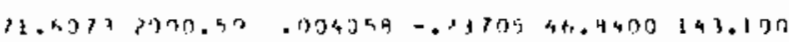
$71.53772007 .54 .004179-2370544.0403143 .100$

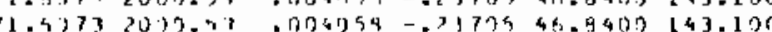

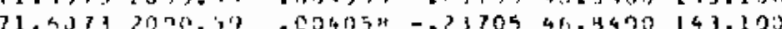

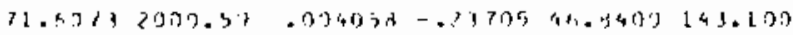
71.

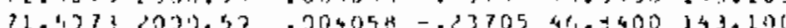

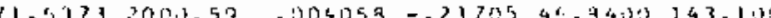

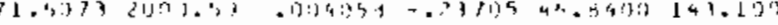

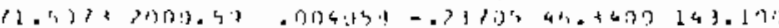

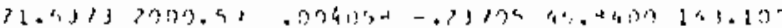

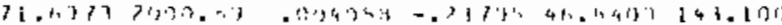

$\begin{array}{lll}230 & 1 & 289 \\ 230 & 1 & 281 \\ 200 & 1 & 289 \\ 230 & 1 & 290 \\ 2.30 & 1 & 290\end{array}$

$6 / 1,12: 23$ $315 \quad 11: 24$ $21511: 24$ $? 5 \quad 11: 24$

315 11:?4 t, 1 13 10:1]

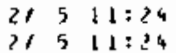

$731: 20$ $31511: 24$ $27,11: 14$

?1 $512: 21$ $\begin{array}{lll}31 & 2 & 1<: 3 \\ 31 & 5 & 12: 30\end{array}$ , 5 12:? $27511=20$ $\begin{array}{lll}27 & 11: 20 \\ c f & 5 & 11: 24\end{array}$ 21 $511:<4$ 37
if 5 11:24

$71311: 26$ 2) $11: 24$

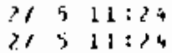

\#) $11: 24$ $\Rightarrow$ b $1 \mathrm{~L}: 24$ 2) $5 \quad 11=24$ म) $111: 54$ 17 b 11:24 $\therefore 511: 24$

$3511: 24$ 3
11 य) $11: 24$ If $11: 34$ 115 11:20
21 1 $1: 2>$ 
AVALOE SHNSTRS

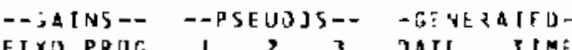

$4, \quad+C-11-10 ;-0 R-2$

$\begin{array}{lll}\text { DEG. FEG. F } & -3301.5 & -2048 \\ \text { OFG. F } & -3301.2 & -2049 \\ \text { OFG } & -2049\end{array}$

$4 \quad I C-31-6, f-5-C$ OFCE, F $-3101,2-234 A$

$47[C-12-40-1] P-4$ DFG. F -3301.2 -2049

an $5 T P-12-59-5 P-3$ DEG. F - $5391.7-2049$

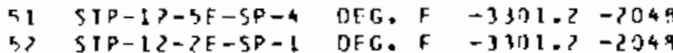

$57 \quad 5 T P-12-2^{A}-5+2$ OFE. $F-3304.7-204 \pi$

DFG. F $-3301.2-204 \mathrm{Q}$

s $\quad T C-1\}-3 A-1 R-2$ DEG. F $-1301.2-2048$

दA $T r-13-6 C-1 R-2$ DEC. F $-3301,2-2049$

$57 \quad i c-17-4 f-1 R-4$

5 S $T C-13-10-1 R-2$

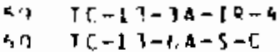

at $[t-1]-6, t-2-t$

(4) $T C-13-1 F-5-C$

का $T C-13-1+2-5-C$

OEG. F - $3331 . ?-20 \% 9$

DEG. F $-3301.2-204 \mathrm{~A}$

DEG. F $-1331.2-2049$

DEC.F $->053.5-1491$ DFG. F $2337.72 \quad 204$ OEG. F $-50.070-16$

45 $S T P-14-5 H-S P-3$ $F \quad 279 ?, 72 \quad 2047$ ah $5 T P-14-5 F-5 P-4$ DFG. F $23+1.72 \quad 394$ , $A$ STP-14-2A-5P-2 DFG. $F$ 2379.12 2047

क) $1 C-\$ 5-40-18-4$

II $T C-1 ;-9,-18-4$

n) $i c-15-4,-1 R-2$

OEG. F $2379.7 ? \quad 3047$ DEG. F 53 YU. 32 2047 DEG. F $2317.72 \quad 2047$

$3 \quad t C-15-1 D-1 R-4$

$74 \quad 1 C-15-3 A-12-2$

$D C G . F-3304.2-2049$ AFe. OEG. F $7349.72 \quad 204$ BFG. F $-330 \mathrm{~L}+2-2040$

ic-is-tik-

DEG. F ?347.72 2047

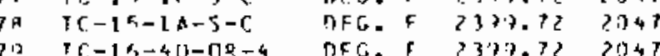

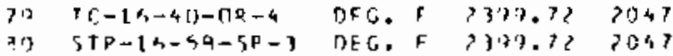

a) STP-1t-5r-5P-4 JUE. F $23 \% .72 \quad 2047$ a) $5 T P-1 h-2 F-5 P-1$ OFG. F $77 .+12$ >194 Q $5 T P-1 h-7 R-5 P-2$ DEG. F $2131.12 ? 304$

$95 \quad T C-1 B-G,-C-C$

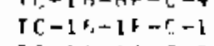

Of G. F $233+.72 \quad 204$ DFG. F $23.7 .72>34$ OFF, $5,7.7 .72,047$

$11.6273 \quad 2000.59 \quad-014054-.23705462 .8400 \quad 143.100$

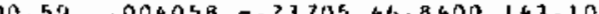

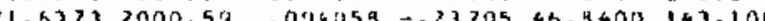

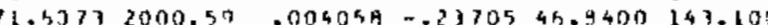

$31.50732003 .57 \quad .004059-.2370546 .4400 \quad 143.100$ $71.43712000 .53 \quad .004054-.7370546 .5470143 .200$ $71,60732020.57 .004049-.2370546 .4400 \quad 143.130$ $71.63732010 .57 \quad .004059-.7370546 .9400 \$ 43.100$

$1.5372009 .57 \quad 0004054-.2370545 .4402143 .100$ $1.43732000 .59 \quad .004054-.2370544 .8470 \quad 143.109$ $71.40732000 .53 \quad .004058-.7370446 .8430143 .100$

$71.63732000 .57 \quad .004050-.3370545 .8400143 .190$ $11.53732000 .54 \quad 004059-.13705$ 46..9400 143.100 . $11.43732000 .59 .004058=.2370543 .4400143 .100$

$71.53732000 .53 \quad .004059-.2710546 .4470 \quad 143.100$ $11.60732000 .59 \quad-004058$-.23705 4h. $4400 \quad 143.100$

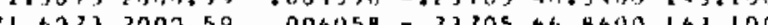

$71.63732000 .50 \quad .004059-.2370546 .9400 \$ 43.100$

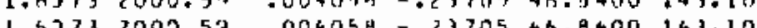

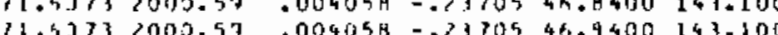
11. $57732000.590004059-.71705465 .54001430100$

$11.53132000,57 \quad .00405 R-.2170544 .4400 \quad 143.100$ $11.5273 \quad 2000.59 \quad .004058-.2370546 .8400143 .100$ $71.1 .0732000 .57 .004048-.2370546 .4400143 .100$

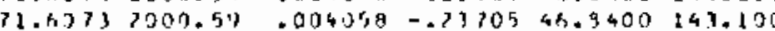

$71.53732079 .57 \quad .004059-.3370541, .4400 \quad 143.100$ 1.5J73 2000.5 . .

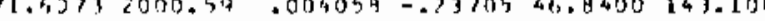
$14.47737009 .57 .004059-.7370544 .4407143 .100$

$1.63712300 .5 \% \quad .006058-.2370 ; 44.94713143 .100$ $71.63732000 .5 \% .004059=2370544.8400143 .100$

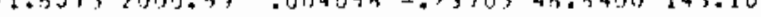
$11.3373 \quad 2300.39 .004058-.2370544 .3490 \quad 143.100$

$11.6073 \quad 2302.59 \quad 0004059-.23705464 .4400 \quad 143.100$

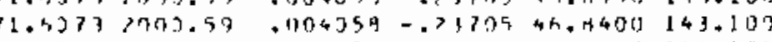

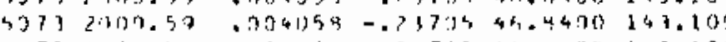

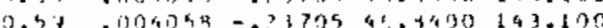

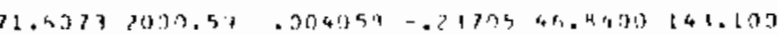

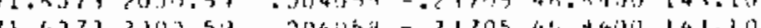
71.

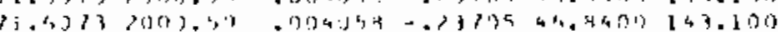

$230 \quad 1 \quad 302$

$230-1102$

$\begin{array}{lll}30 & 1 & 303\end{array}$

303

$230 \quad 12304$

$330 \div 104$

304

$230 \quad 130 n$

200

21 5 11:24 2f 5 11:24 $315 \quad 11: 24$

$312 \quad 15=31$ b/20 $): 43$

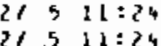
$21511=29$ $21511: 24$ $7311: 24$

$21511: 24$ 2f $11: ? 9$ $21511: 24$ $21511: 24$ ?f $511: 24$ 2f 5 11:24 यदि 11:24

$37511: 24$

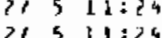
275 11:24 $37511: 24$

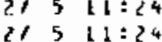
21, 5 11:24

$21511: 24$ $21511: 24$ $\begin{array}{lll}27 & 5 & 11: 24 \\ 21 & 5 & 11: 24\end{array}$ $21511: 24$ ?) 5 11:24 9127 13:35 $27311: 24$ $71311: 24$ 23 5 11:24 ?f $511: 24$ $21511: 24$ $11311: 24$ 
ANAL.ZG SENSOR5

a) $I C-17-40-1 R-4$

TC $-17-30-10-5$

$1+T-17-3 c-1 R-2$

iz $\mathrm{T}(\mathrm{C}-\mathrm{I}] \mathrm{l}-4 \mathrm{C}-\mathrm{TR}-\mathrm{C}$

$T C-17-30-[R-C$ $T C-1>-3 C-i R-C$

$T C-1>-30-1 R-3$

7 ic -1$\}-3 c-1 Q-7$

$T C-17-5 B-1 R-3$

TC-17-2E-1Q-1

101 IC- $C 7-2 A-1 R-7$

In $T C-17-5 E-1 R-C$

II) $\mathrm{TC}-17-2 \mathrm{~T}-1 \mathrm{~K}-\mathrm{C}$

$10, \quad t C-1\}->B-16-C$ 10k $T C-17-5 A-[H-1$

$\begin{array}{ll}1 \cap 7 & T C-17-5 E-1 R-2 \\ 194 & i C-17-2 F-[R-3\end{array}$

Lo. $T C-17-2 A-[R-4$

$110 \quad T C-1]-5, A-5-C$

il $r e-17-4,-5-6$

li? $t \mathrm{C}-1+1+1 \mathrm{~F}-\mathrm{S}-\mathrm{C}$

$113) 3[-17-1 A-5-C$

114 TC-19-4O-1R-4

$11 *$ TC-19-5C+TR-3

117 TC-19-50-17a-3

$11 A \quad T C-1 A-4 F-n R-4$

$1>0 \mathrm{~T} C-19-20-0 \mathrm{P}-1$

1?1 TC-1.9-2C-OK-1

1) $T C-19-3 C-1 R-4$

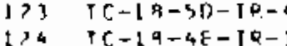

$175 \quad \mathrm{IC}-1 \mathrm{a}-3 \mathrm{~F}-1 \mathrm{Q}-$

1) $\quad(C-1 B-20-16-$

1) if $-1 x-5 c-16-2$

rela bavist

$1>3 \quad T C-1, y-t, 2 t-2-C$

13 i $\mathrm{C} C-1 \mathrm{a}-1 \mathrm{~F}-\mathrm{F}-\mathrm{C}$

i) $\quad C C-1 A-1 A-5-C$

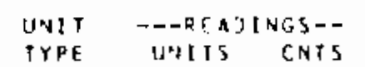

DFG. F 2309.7? 2047

DEG. F $239.12 \quad 2047$

DFG. 279.72 ?047

BFG. $F-3301 . ?-2049$

DFC. F -3301.? -2049 DEG, F $\quad+301.2-2049$ DEG. 2379.72 2 1948

QEET F 237.7.7? 2047 OFG. F ?370.72 2047 DFG. F 2317.7? 204 DEG, F 237.7? 2047

OEG. F $3377.72 \quad 2347$ DFG. F $73 \neq 7.12$ ?09? OFE. F -3311.2 -204A
OF.

DEG. F 2377.7? 2047 DEG. F $7789.72 \quad 7047$ $\begin{array}{lll}\text { IJFG. F } & 339.17 & 2367 \\ & 337.72 & 2347\end{array}$

OEG. F - -3301.2-704A OFG. F 2377.7? 2047 DFe. F - $F 191.2-204 \mathrm{n}$

DEC. F -3301, - -2349 DEG. ? ?194.1? ?114? DIG.F $230 \% 7 ?$

DEG. F $2377.72 \quad 2047$ BFC. F P3r? 2047 $D E G$ F $23,2 ? 204$ ? DF.t. F ?311.7? 204? nis. $2373.12 \quad 2347$

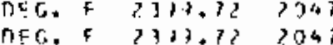

OEG. F 23\%,72 204 ?

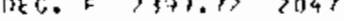

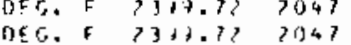
DE. F F -331., $\rightarrow 94 a$ DFG. $53,3,3,2 \cdot 34$

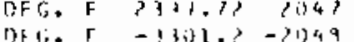
DEF, F ?379.7? 204?

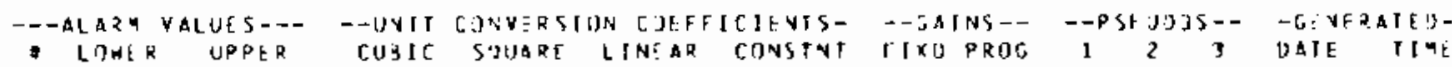
$71.307320130 .59 \quad .004059-.7370546 .9400 \quad 143.100$ $71.63732000 .57 \quad 004054-.23705451 .5470143 .100$ $71.4073 \quad 2000.59 \quad 004059-.2370544 .8400 \quad 143.100$ $71.60732000 .54 \quad 004053-.737054 h .4400143 .100$ $11.33132000 .54 \quad .034059-.23705 \quad 44.9400 \quad 143.100$ $71.67737000 .59 \quad .004059-.2370546 .4400 \quad 143.100$ $0373000.50 .004058-.2370546 .8403143 .100$ $0.0,930$ 6.66.970 .002000 .003000 15.2001450.000 .002000 .00300013 .0001450 .000

$71,43732000.57 \quad .004054-.237954 p .4400143 .100$

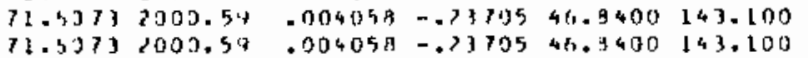
$71.60732000 .59: 004059-.7370546 .3400143 .100$

$11.53732000 .59 \quad .004058-.2370545 .9400 \quad 143.100$

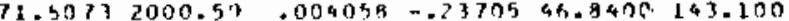
$7(, 5) 732000.59 \quad .00405 B=.2310544 .9400143 .100$ $71.5273 \quad 2000.57 .004058-.2370540 .4400: 143,100$

300

$230 \quad 1314$

$\begin{array}{lll}230 & 1 & 314 \\ 730 & 1 & 312\end{array}$

$21511: 2$ 21 $511: 24$ $21 \quad 5 \quad 11: 24$

$21 \quad 5 \quad 11: ? 4$

$71.53732000 .57 \quad .0134059-.7170546 .9400143 .100$

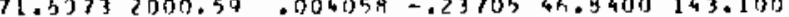
71.53732000 .59 .02405A $=.237054 h .9400$ la3.190 $71.53732070 .57 \quad 003054 \quad-.7370545 .9400243 .800$ $71.53772030 .53 \quad .004058-.2170546 .5400 \quad 143.100$ $71.5073<000.54 \quad .004058-.2370544 .9400143 .100$ $71.63732000 .57 .004058-.3370546 .3400 \quad 143.200$ 71.53732000 .57 .004058 -.23705 44.9400 143.100 $11.33732007 .59 .004059-.7370543,4400143.200$ $71.5373 \quad 2090.59$.004054 -.23705 45.8400 143.100

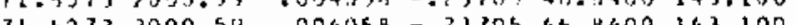

$71.40732070 .59 .004054-.7373542 .0400143 .100$

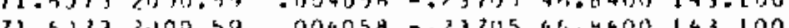

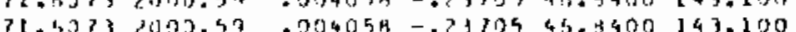

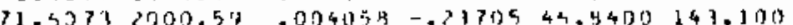

$71.4373 \quad 1090.39 .074059-.231354404400143 .100$ $71.5371<1379.57$.014054 -. ?377n5 46..3400 143.200 $71.6073 \quad 21303.57 .004054-.7377544 .4400143 .1700$ $71.53732000 .57 .004054-.2310446 .01400143 .100$

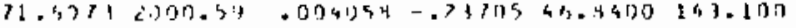

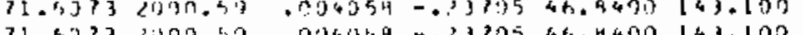

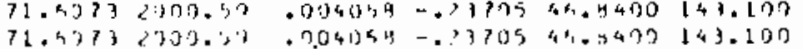

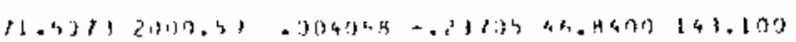

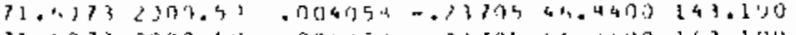

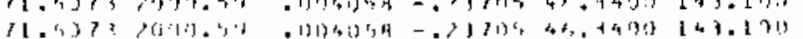
if 5 11:26 81, $11: 24$

$31511: 20$ ?1 5 11:24 if 5 11:24

$71511: 24$ $21311: 24$ $\begin{array}{llll}21 & 5 & 1 & 1: 24 \\ 21 & 5 & 1 & 2\end{array}$

2) 1312

$300+314$

1315

115

315

$230+350$

$330-1113$

301313

$\begin{array}{lll}500 & 1 & 315\end{array}$

7301013

$330 \quad 1315$

$330-1316$

$\begin{array}{ll}730 & 1 \\ 270 & 116\end{array}$

$230 \quad 1 \quad 316$

230

300

239

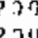

$\rightarrow 0$

21 4 11:?4 21 $511=? 4$ $\begin{aligned} & 215 \\ & 21\end{aligned} 511=29$

$21,11: 24$ $21511=24$ $21511: ? 4$

$315 \quad 11: 24$ $215511: 24$ it $5 \quad 11=24$

775 11:24 215 11:24 21 $5 \quad 11: 24$

31 क $11: 24$ $\begin{aligned} & 275 \\ & \geqslant 1\end{aligned} 511: 24$ 2) 5 11:?4 27 $511: 14$ $? 511: 24$ $215 \quad 11: 74$ ?1 $511: 24$ it $411=27$ मो 1क:
$200 \quad 1 \quad 314$

21 $311: 24$ 
AHALUG SFNSORS

$113 \quad \mathrm{TC}-200-01 \mathrm{t}-3$ $134 \quad 5 T P-2 n-0 T-2$

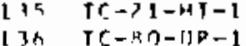

$\begin{array}{ll}137 & \text { TC }-17-3 C-18-1 \\ 170 & \text { IC }-1>-30-18-4\end{array}$

139 INDEFINED
140 UVUEFINED

141 5PND)-3-40-18-2 E13 NV .000003

(4) SPN[1-3-6F-5-3 El3 NV -00163

143 SOVI)-3-1A-S-1 ह13 NV $=.0207$

144 SPYก $-6_{1}-4 R-1 R-2$ \& 13 NV -.01707

149 SPND-R-FA-S-2 E13 NY -.52AJ7

1 Lh SPNIS-R-1F-5-4 $513 \mathrm{NV} \quad 971254$

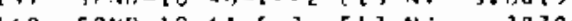

147 SPNM-10-hF-S-3 EL $N V$.00000 5n SPND-1D-1F-S-4 F13 NV -.0131?

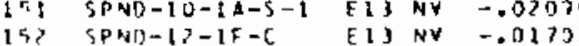

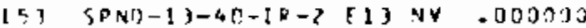
$15.5 S^{2} N(5-13-2 A-5-2$ E 13 NV -.0210

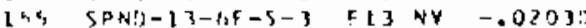
14h 5PAS-13-1F-5-4 EI3 NV -.01ti4

I57 5PVI-13-1A-5-1 FI3 NV -.0174 137 5PHO-13-4n-1Q-7 F13 NV $-1.2410-10$

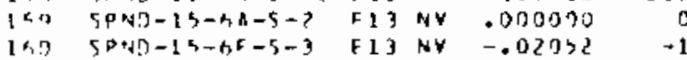

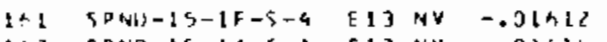
1 ST SPND-15-1A-S-1 E1\} VY -.01514 la SOND-1f-1\%-C $513 \mathrm{NV}-.0173$ $16,50180-17-4 n-[0-2$ F 13 NV -.0170 1,5 SPNO-17-6, loh $5 P \times[1-17+h F-5-3$ [13 NV -.0017

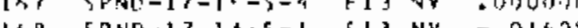

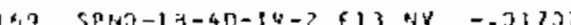

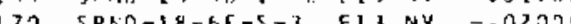
171 SPAIS-1B-1A-S-1 F.13 VY -.01531 17 UNOEFIAIT

173 Negratit4

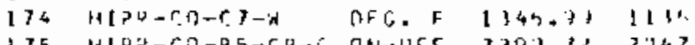

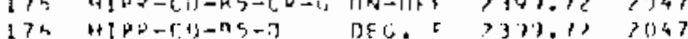

\section{- lijar uppir}

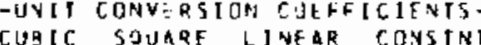

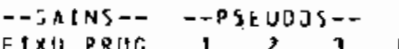

IXU PQLTC

DAE TIME

$71.35732000 .59 .004039-.2370545 .8400 \quad 143.100$ $71.63732000,50.00405 A-.2370546 .8400143 .100$ $71.50732000 .57 .00405 A-.23703 \quad 4 \% .3400 \quad 143.100$ 71.63732000 .59 .004059 -.7370546 .8400143 .100$

$71.50732000 .57 \quad 004058-.237054 h .8400243 .100$ $71.63732000 .57 .024058-.2370548 .8400143 .100$

230

300

730

1

1314

3.550333 .59033 .000000 .003000 .073474 .000000 $3.54943 \quad 3.44343 \quad .005000 .005000 .003347 .009090$ $3.5337 \mathrm{~K} 3.5337 \mathrm{~B}$

3.551103 .55110 .000000 .000000 .003351 .000000 3.542333 .54253 .005000 .003000 .003325 .000030 3.553333 .54033 .000000 .000000 .003494 .003000 3.554303 .55430 .003000 .003000 .004520 .003000

$3.55283 \quad 3.55283 \quad .002000 .003000 .004156 .003000$ $3.545593 .54559 \quad .000000 .030000 .003279 .000000$

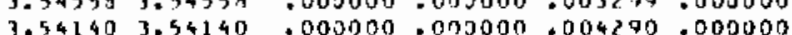
3.553333 .55313 .003000 .003000 .003434 .000000

$3.553333 .55033 \quad .003000 .000003 .003474 .000000$ $3.537473 .5334 \% .003000 .003000 .034313 .003000$ 3.5528333 .55293 .000000 .000000 .004156 .003000

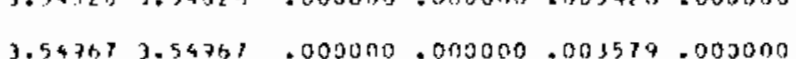
$3.557003 .55033 \quad .000010 .00000$ $3.5471 \mathrm{~h} 3.547210 .000000 .092000 .004200 .000000$

$3.54554 \quad 3.54559 \quad .000000 .003000 .003279 .000000$ 3.5528901 .55287 .000000 .003000 .003305 .003000 3.553333 .54333 .000000 .005000 .003494 .000000 3.553333 .55337 .000000 .000030 .003414 .000007

3.541403 .541413 .005000 .007000 .004240 .002000 $3.54427 \quad 3.44427 .000070$.000000 .000355.002000

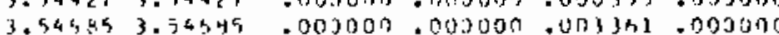
$3.447013 .54701 .003000 .00000 n .003245 .003000$

3.550313 .55933 .003000 .034900 .003434 .005000

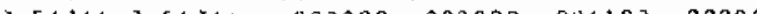

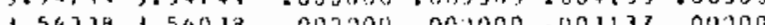

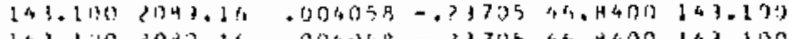

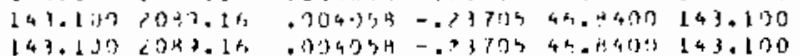
$215 \quad 11: 26$

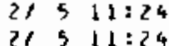
$\begin{array}{lll}21 & 5 & 11: 24 \\ 71 & 5 & 11: 24\end{array}$

9:3 $11: 11$ $97217: 12$ $912317: 13$
$912317: 15$

अ123 17:15 $912311: 17$ $9 / 2317: 1$ $9723: 7: 1$

$9,23 \quad 11: 21$

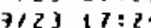
$7123 \quad 17: 25$

$782317: 21$ $9 / 2311: 28$ $+173 \quad 17: 27$
$412317: 43$

$3123 \quad 17: 42$ $9723 \quad 17: 44$ $723 \quad 17: 45$ $4 / 23 \quad 17: 45$

$9 / 23 \quad 17: 48$ 723 17:4 7123 17:53 $7 / 23$ 17:51

का? $17: 5$ ? $4115 \quad 10: 13$ $712317=55$

7/2) 17:5; $\begin{array}{ll}7127 & 10: 43 \\ 723 & 17: 37\end{array}$ 
ANALOG SENSORS

$--T A S A S--$

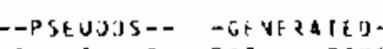

177 UNDEFIVEN

178 HIPR-CA-AB,

LBO HIPQ-CD-CQ-O DFG F - 10575 - 519

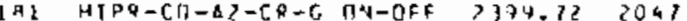

(9) $H I P R-C \Pi-A 2-0$ DEG.F $-3301.2+204 B$

IR U UNEFFINED

IA4 H[PK-CI-R4-W DEG. F -3273.3-200A

HS UNDFFINED

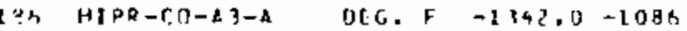

IQ7 UNOEFINE

LAH MIPP-CE-AI-W DEG. F -224B.D-157A

1 TQ UNUEFINFD

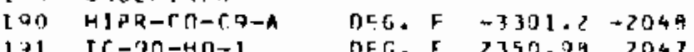

1?) $T C-O M-H D-2$

DEG. F 7350.992047

DFG. F 2350.49 206?

I.j) te $-90-40-3$

DFG.

I $\quad 394 \quad$ TC, $\rightarrow 00-\mathrm{HDT}-4$

DEG. F - -205 ?. -2048

$71.50732000 .57 \quad 00405$ B -.2370544 .8400143 .100$ $71.60772000 .59 .004059-233755469400143.100$

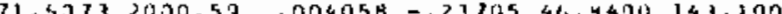

$71.53732000 .54 \quad .094059-.7370546 .4400143 .100$ $71.52732000 .53 \quad .004054-.2370448 .8400141 .100$

71.63132000 .59 .00405 A $+.2370546 .8400 \quad 143.100$

230

$71.52732000 .57 .004058-.2370544 .8400143 .100$

$71.30732000 .57 \quad .004058-.7310546 .04000143 .100$

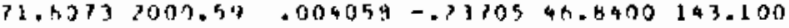
11.75232000 .36 .000000.000000 44.0316 147.470 71.75232000 .36 .005000 .00300044 .3316143 .400

230
320 320

$71.35292000 .36,003000.00000044 .3116149 .400$ $71.75272000 .36 \quad .000000: 00300044.3116,149.400$

(30) 1324

$9174 \quad 1: 9$

$3 / 24$ ?:

$7 / 24 \quad 1: 13$

$9124 \quad 0: 11$

$724 \quad 7: 12$

$724: 1: 14$

$7114: 15$

$1 / 24 \quad 1: 12$

$9 / 24 \quad 7: 1$

$21 \leq 0 \quad 7: 28$

$712,17: 5$

41:3 $17: 5$

196, UNDEFIVFO

777 UNDFE IHED

JTR INDDCFIVED

13 UNOFFIAED

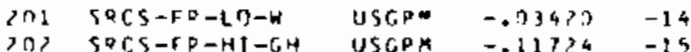

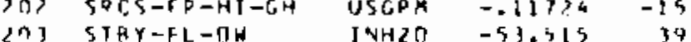

204 UTLP-PP-FS-5-1 PSIA TOP.S74 -1

205 UTLP-TA-PS-0Q-1 D5IA $-17.171,10$

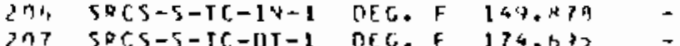

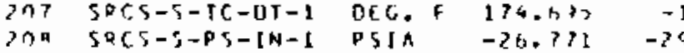

701) SRCS-5-P5-DT-1 PSIA 59.077 134?

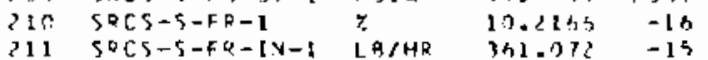

21) SRCS-S-FR-DT-L LAPHR 70.4413 183

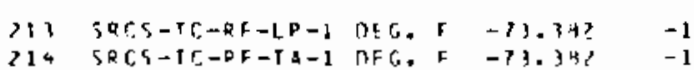

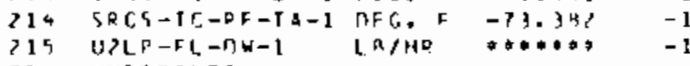

$-1$

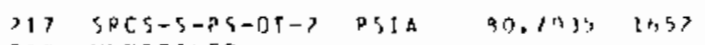

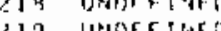

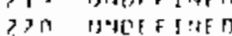

$4.777554 .77755 \quad 0002000.003000 .001000 .003000$ $4.974634 .97643 \quad .0030700 .003000 .003700 .002000$ $24.144124 .1491 \quad .003002-.00002 .093360-62.203$

$-1,1.377-1,1.077 \quad .0050100 .030000 .012500-12.500$ $27.2534379 .479 \quad .000000 .002007 .053000150 .090$ $27.7229710 .424 \quad .002000 .0139000 .125000175,030$ $27.210571 .734 . \quad 000000.003000 .025000-25.000$

$27.208157 .7533 \quad .003000 .003009 .025000-15.000$

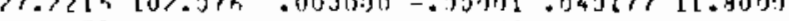
सम.177s 174. 27.2338 253.36h .000000 -.20002 .173440 29.7000

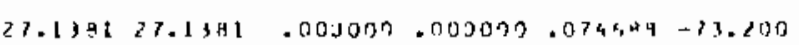
$-634.07-434.07 .000000 .003090 .074349-73.220$

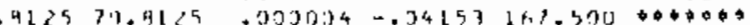

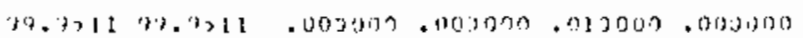


ANAL JG SENSORS

\begin{tabular}{|c|c|}
\hline N:J ${ }^{4}$ & NAME \\
\hline$? .7 !$ & U] $1 D-P C-[N-1$ \\
\hline $7 ?$ & UZLP-TC-OT-1 \\
\hline 273 & UNDETINEN \\
\hline $2 \geqslant 4$ & UTDEF INFD \\
\hline 225 & UNDEFINED \\
\hline 226 & JNOTFINED \\
\hline$\geqslant$ & UNDFFINFO \\
\hline $2>$ म & UNCEFINFT \\
\hline 777 & UNDEFINEN \\
\hline 233 & UNDEF I NED \\
\hline 231 & UNDFF JUER \\
\hline $3 \%$ & UNOFFINEO \\
\hline 233 & UYDEFINEO \\
\hline 234 & UNDEFINED \\
\hline 275 & UNAFF INAD \\
\hline $3 x$ & UNDEF INEA \\
\hline 237 & UNDEF 1 MEO \\
\hline 274 & 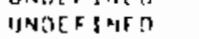 \\
\hline$i n$ & WNBFF INEO \\
\hline$z<0$ & UNDE F TAEO \\
\hline 241 & UNDFFINFO \\
\hline 347 & UNOFF INET \\
\hline 343 & UHOF EINED \\
\hline 744 & DFF-1 \\
\hline
\end{tabular}

$$
\text { PFF-1 }
$$


$59 ? 3$

- *4 sensur status pepart *0

$3 / 27 / 80$ 15:77:5?

DICIIAL SEVSORS

N1)

NAME

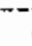

0 - TIATES:-

-REAOING-

- ALARAS-
- STATF

TPEN

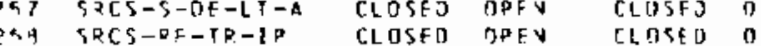

5SA SRCS-OE-tr-i

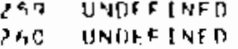

IAl UMDERINET

IS? UNCFFINED

IF] UNOEFTNFD

204 UNOEFINEO

ThS UNDEFINED

IDS UNDFF JHED

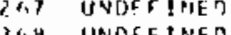

51,0 UNOFE TRE

STO HNOFFFINGO

$? \rightarrow 1$ INDOFINED

$7 \%$ WNDEF INED
$2 ? 2$ WNDFEINEO

27) UNDFEINFD

I 274 UNDEFTNED

275 IJNDF FJNEO

$27 \mathrm{H}$ UIDFINED

237 UNDFEINEO

77 UINDFFIDED

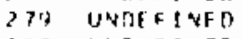

28ก WVIEFINED

THL UNGEFINEO

?R5 UNJTFE INED

2म J IHOFF INF

2 व 4 UNOFFIDF?

245 JNDEFINE

PUS UNTEFINEO

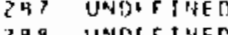

TPEN

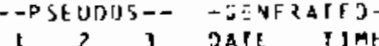
DATE IJME

$51210: 12$ और 10:23 
PSEUDO SENSTRS

$004058-.73705 \quad 43.8409 \quad 143.100$
0.004058

203 PSO-4-5-1

295 PSO-4-5-1

27h PSD-7-OR-1

DEG.

INCITPLFT

DEG. F INCIJPLE TE $571.53732000 .57 \quad 00405$ A -.2339544 .5400143 .100$ 1h $71.03732000 .57 .004058-.7370546 .8400143 .100$ 6 $71.43732000 .57,00405 A-.2370546 .8400143 .100$

DFG. F TWTIYPLETE

OEC. F 1NETYPLET

DEC. F TYCJMPLETE

78 p $50-9-5-2$

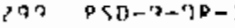

120 PSO-7-5-2

301 PSD-10-5-1

392 PSO-11-0P-1

$301 \quad P 50-11-5-7$

304 PSD-17-50-1

$3 \cap 350-15-2-7$

310 PSD-1h-5P-1

3i) $P S O-17-10-1$

$31: \quad 65 D-17-10-2$

314 PSD-17-[R-3

31. $P S O-17-5-4$

11 P $\quad 105-1 \mathrm{R}-10-1$

319 P $50-18-18-2$

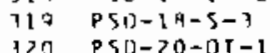

$3>1$ PSO-17-ST-h

अP PSD-ID-PSO

373 PSD-10-PS-2

$x>4$ >5D-7n-HO-1

375 pSU-17-ps-3

33, UNDFE TIFE

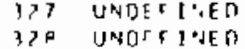

DEG. $F$

$D E G . F$

De.

INCOYPLETE

INCTAPLE IE

IYCTYPLEIE

INCOYPLF T

DEG F INCOYPLETE

CO $T$ TAJ OS

DEC. -793.35 - 860

DEG.F IVCDYPLEIE

DEG. F TNCOAPLETE

DFG. F IVCUMPLETE

DEG. JN TYTPLEIE

DEC. F INCOYPLEIt

OFG. F IVCTYPLIE

DEG. F IVCIJPLEIE

DEG. F INCTMPLETE

DEG. F TVCJYPLETE

$\begin{array}{ll}\text { DFG. F } & \text { IYCJYPLEFE } \\ \text { OFG. F } & \text { INCTMPLFE }\end{array}$

KN/Fi -0.0017? -1

DEC. F TVETAPLETE

DFE. TR TNCTMLE

DEG. F IRCOMPLFtK $71.50732000 .57 \quad .00405 R-.2370546 .0400 \quad 143.100$

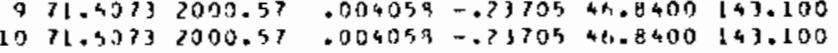

$1171.6373 \quad 2000.57 \quad 004059 \quad-.23705 \quad 46.9400 \quad 143.100$

$1271.50732000 .57 \quad .004054-.2370544 .0400143 .200$

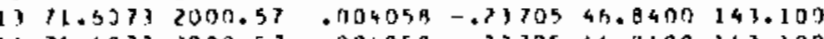

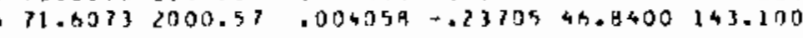

$71.5373377 .493 \quad .004059-.2370540 .8400143 .100$ $71.53712000 .57,00405$ H -.7370546 .9400143 .100$ 71.5373 2000.57 .00405A -.73705 4h.6400 147.10J

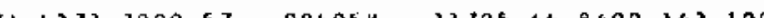
71. $71.5373,2000.57 .004059-2370546.4400143 .100$ $71.43732000 .57 .004059-.7370546 .9400147 .100$

$11.52732000 .57 \quad .004058-.7370546 .9400143 .100$ 71.43732000 .57 .004058-.7370546.8400 143.100 $71.43732000 .57 .004059-.7170546,8400143.100$ 11.53732000 .57 .004059 - 2370546.3400143 .100

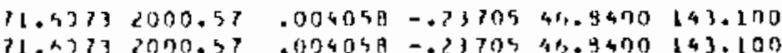
$71.4373 \quad 2000.57$.604048-.23705 4t.9400 143.100

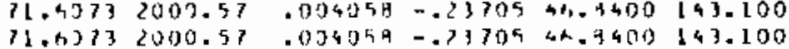

$330 \quad 1$

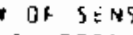

- GLNEZATESB330

4 , 10:17 $215 \quad 11: 11$ ?) 5 11:1?

if 5 11:17 $27511: 17$ 215 11:17

2f 5 11:11 215 1 $1: 17$

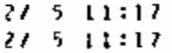
1/ 5 11:11 215 11:57

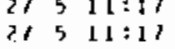
b/ 17 1:4:4) यद $111: 17$ का क $10: 13$

$2151: 1: 13$ $\begin{aligned} & 21 \\ & 21\end{aligned} 511=3$ ? औद $51:=17$ $75 \quad 11: 17$ $5 / 5$ 1 $10: 13$ 11 $511: 17$

it 5 11:17 $375 \quad 11: 17$ $71 ; 10: 17$

$.4073 \% .40737 \mathrm{~h} .003030 .003000 .003477 .003000$ 143.1002049 .14 .004058 -.23705 4h.0400 [43,100 $71.53732000 .57 .004049-.2370446 .4400143 .100$ $.124317 .124512 \quad .006054-.3170444 .3470 \quad 143.100$

$143.1002082 .160 .00405 \mathrm{H}-.3789546 .4400 \quad 143.100$

, I 1 $133+$ 317 b: 313

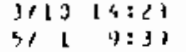
$4110: i 1$ 
४4र3

Nu* Name

333 UNDFFINET

334 UNDFF INF

I35 UNDEFINED

33 G UNDEF INED

33 UNUEFINED

TBP UNDFFINED
* SENSBR STATUS REPUgT *at

Q/27/40 15:40: ก

PSEUDO SENSORS

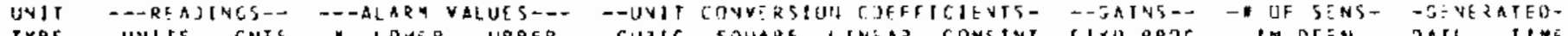

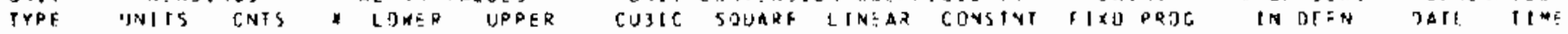





\section{DISTRIBUTION}

No. of

Copies

OFFSITE

A. A. Churm

DOE Patent Division $9800 \mathrm{~S}$. Cass Avenue

Argonne, IL 60439

400 U.S. Nuclear Regulatory Commission

Division of Technical Information and Document Control

7920 Norfolk Avenue

Bethesda, MD 20014

2 DOE Technical Information

Center

5 R. Van Houten

U.S. Nuclear Regulatory Conm is sion

Fuel Behavior Branch

Division of Reactor Safety Research

Washington, D.C. 20555

6 C. A. Herriot

Chalk River National Laboratory

Chalk River, Ontario

Canada
No. of

Copies

ONSITE

33 Pacific Northwest Laboratory

C. L. Mohr

W. J. Bailey

W. D. Bennett

L. W. Cannon

E. L. Courtright

K. E. Davis (6)

M. D. Freshley

R. L. Goodman

C. R. Hann

G. M. Hesson

L. L. King

R. K. Marshall

P. N. McDuffie

C. Nealley

L. J. Parchen

G. E. Russcher (3)

N. J. Wi ldung

C. L. Wilson

E. A. Jenkins

Publishing Coordination (2)

Technical Information (5) 

NAC FOMN 335

17.77)

4. TitLE AND SUBTITLE (Ado Volume Na, if eppraprian)

2. (Lowe blenk)

Experiment Operations PTan for a LosS-of-Coolant Accident Simulation in the National Research Universal Reactor

3. RE CIPIENT'S ACCESSION NO.

7 AUTHOR (S)

G.E. Russcher, L.W. Cannon, R.L. Goodman, G.M. Hesson, L.b. King, P.N. McDuffie, R.K. Marshall, C. Nealley, 9. PERFOAMING ORGANICATION NAME AND MAILING ADDRESS (Include Zip COde)

Pacific Northwest Laboratory

Richland, WA 99352

5. OATE AEPORT COMPLETED MONTH TYEAR October 1980

DATE REPORT ISSUED

\begin{tabular}{l|l}
\hline MONTH & YEAR \\
\hline TPYTI
\end{tabular}
Apri1 1981

6. (Love bionk)

8. (Lewe bonk)

12. SPONSORING OAGANIZATION NAME AND MAILING ADDAESS (inciude $Z$ ip Code)

Division of Reactor Safety Research

Office of Nuclear Regulatory Research U.S. Nuclear Regulatory Commission Nashington, DC 20555

10. PAOJECT/TASK/WORK UNIT NO

11. CONTRACT NO

FIN B2277
13. TYPE OF REPORT

Experiment Plan

15. SUPPLEMENTARY NOTES
PEAIOD COVE RED (Inclusive dares)

$N / A$

\section{ABSTRACT QDO words or iess!}

This document contains the experiment proposal and assembly proposal information for a series of parametric thermal hydraulics loss of coolant accident tests in the Canadian NRU reactor. These tests will establish the relationship between reflood delay time, reflooding rate, and the resultant fuel rod cladding peak temperatures.

17. KEY WORDS AND DOCUMENT ANALYSIS

Reactor Test Readiness

Reactor Test Procedures

Operating Control Limits

Safety Review

LOCA Heatup and Reflood 17a. OESCRIPTORS

Reactor Test Readiness

Reactor Test Procedures

Operating Control Limits

Safety Review

LOCA Heatup and Reflood

176. IDENTIFIERS/OPEN-ENDED TERMS

18. AVAILABILITY STATEMENT

Unlimited

19. SE CURITY CLASS (ThIS NDORI Unclassified

20. SE CURITY CLASS TThis popel Unclassified
21. NO. OF PAGES

22. PAICE

$\mathbf{S}$ 
